\title{
مشروع التجديد الفكري عند ابن خلدون
}

\section{عزمي طه السيد}

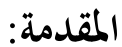

انعقد إجماع الغالبية العظمى من الباحثين في قضايا الفكر والعلوم الاجتماعية على أن ابن خلـدون مفكر أصيل مبـدع، وعى أوضـاع عصـره وأحسداثها، وأوصله وعيه هـذا

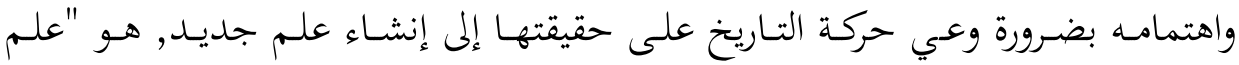

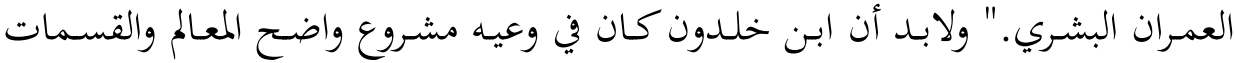

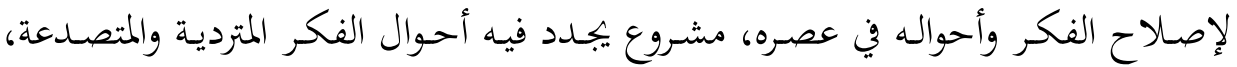
معتمدا على منهج علمي واقعي، وعقلانية عملية منضبطة بضوابط العقيدة الإسلامية. فكرة توافر هـذا الوعي عند ابـن خلدون هي الفرضية التي سينهض هـذا البحثث للتحقق منها، مؤملين أن نجد في تجربة ابن خلدون الفئ إكرية ومشروعه الفكري فكرة نعتبر

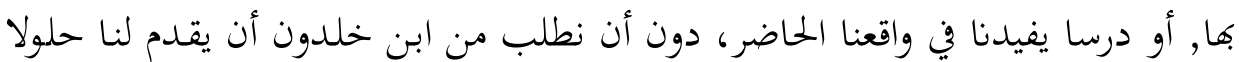

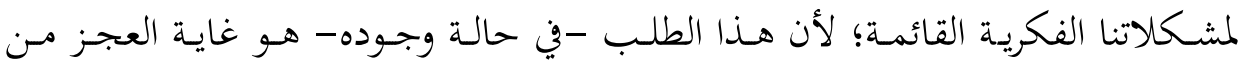
جانبنا.

إن مفكرا أصيلا يعيش عصرا هذه صورة أحواله، ويقوم بوصفها وصفا علميا، يقول

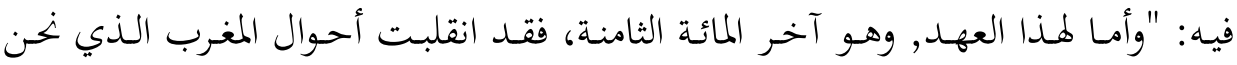

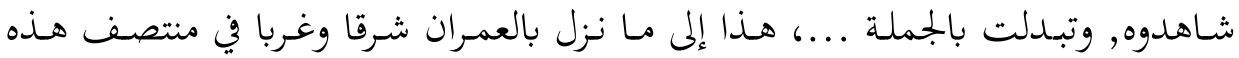

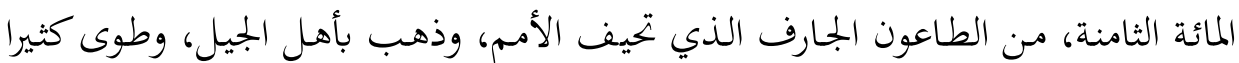

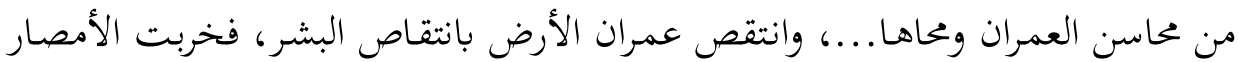

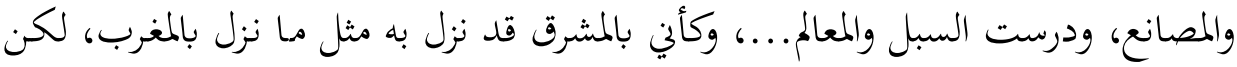

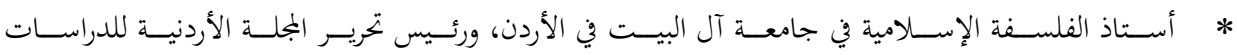
azmitahaa@hotmail.com الإسلامية. 
على نسبته ومقدار عمرانه، وكأنما نادى لسان الكون في العالم بالخمول والانقباض فبادر

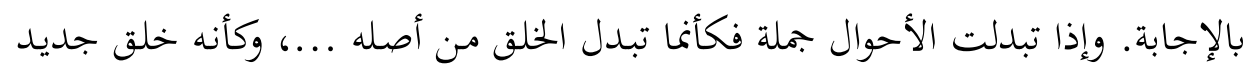

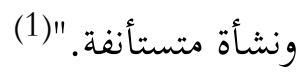

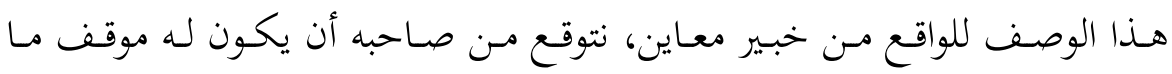

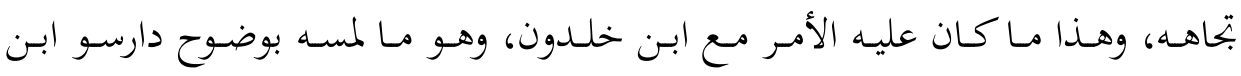

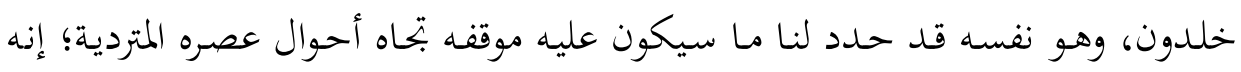

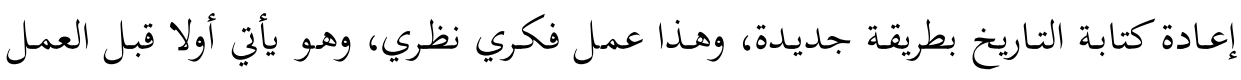

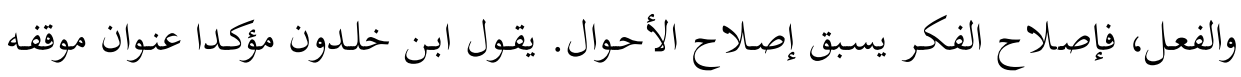

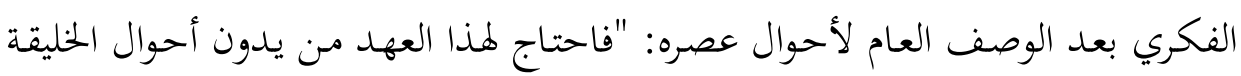

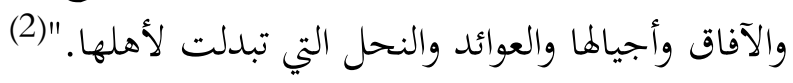
هذا التدوين للتاريخ لا بد أن يكون وفقا لفلسفة في تدوين التاريخ جديدة، وأن يتم بطريقة جديدة تتلافى الأخطاء وجوانب القصور التي وقع فيها المؤرخون والمفكرون قبله،

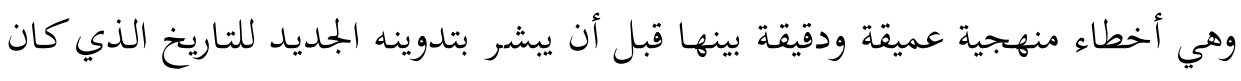

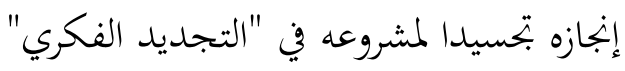

ويحاول هذا البحث أن يوضح عددا من جوانب هذا المشروع التجديدي، ولا سيما في أربعة بجالات هي علم التاريخ، وعلم الكلام، والفلسفة، والتصوف، ويستخلص من ثمانم بعض معالم هذا المشروع الإصلاحي.

\section{أولا: فكر ابن خلدون ومشروعه:}

نتحـدث هنـا عن مشروع فكري سينهض ببنائه وبيانه ابن خلدون، ويتصف هذا

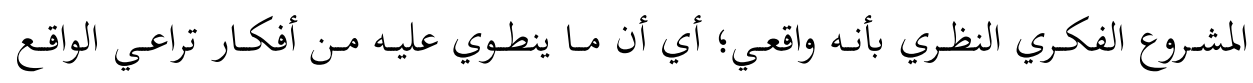

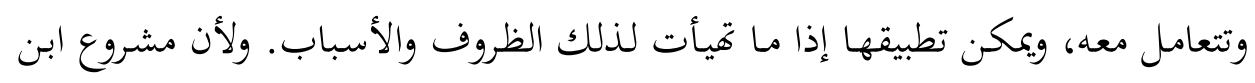
(1) ابن خلدون، مقدمة ابن خلدون، تحقيق: علي عبد الواحد وافي، ط3، القاهرة: دار هضة مصر للطبع والنشر،

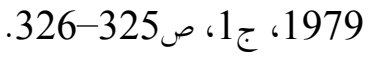

$$
\begin{aligned}
& \text { المرجع السابق، ج1، ص19 ص326. }
\end{aligned}
$$




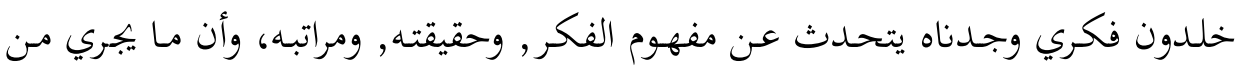

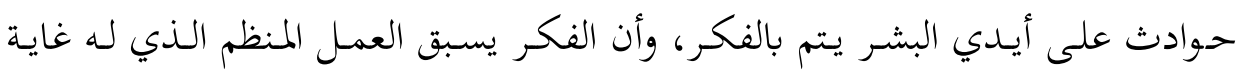

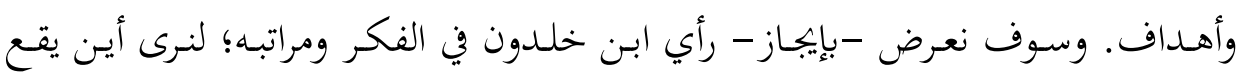
مشروعه الفكري من مراتب الفكر. مدرف

الفكر - في نظر ابن خلدون - هو ميزة الإنسان التي تميزه عن الحيوانات الأخرى،

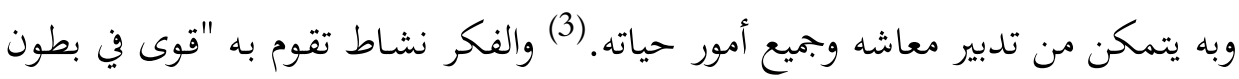

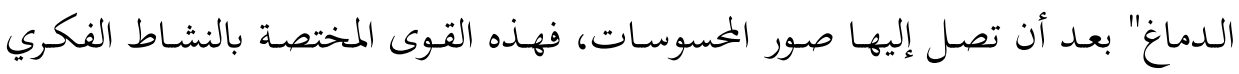

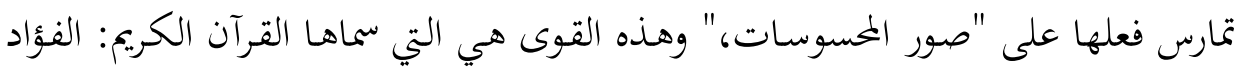

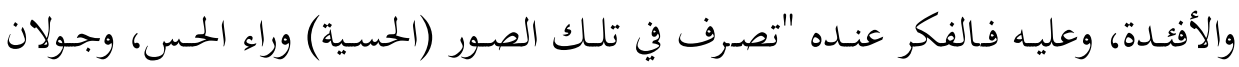

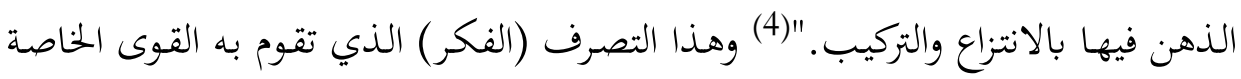

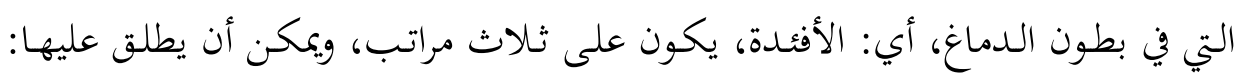

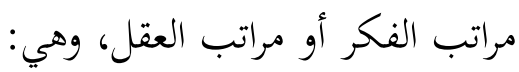
1. الفكر أو العقل الذي يدرك الأشياء الموجودة في الخارج فيصل إلى معرفة أهم

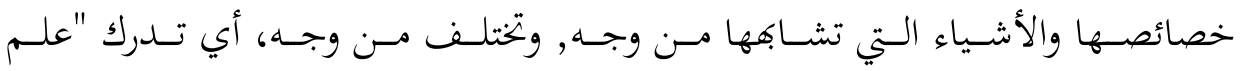

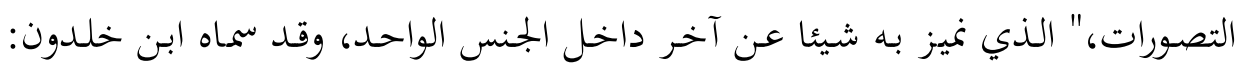

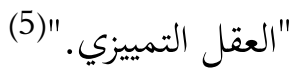
2. الفكر أو العقل الذي يقوم بتحديد قواعد المعاملات بين الناس، والآداب التي

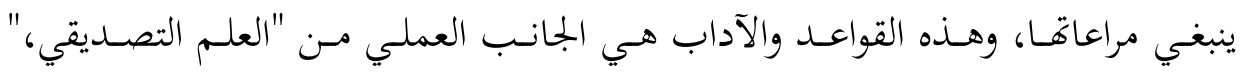

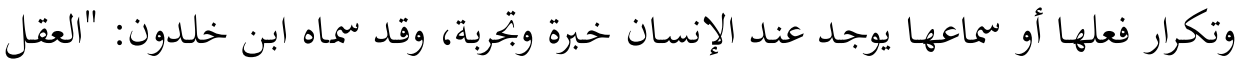
التجريبي؛"(6) إذ يقوى نشاطه وإدراكه بتكرار التجربة.

$$
\begin{aligned}
& \text { (3) المرجع السابق، ج3، ص1007-1008، المرجع }
\end{aligned}
$$

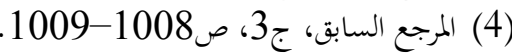

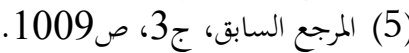

$$
\begin{aligned}
& \text { (6) المرجع السابق، ج3، صلمب، ص1009. }
\end{aligned}
$$




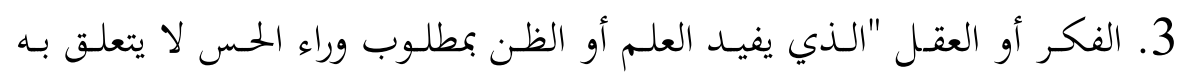

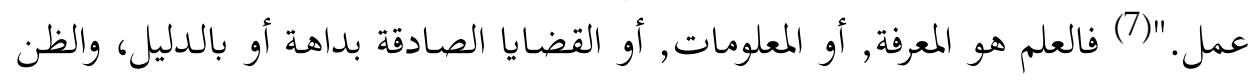

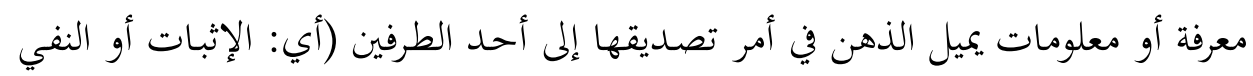

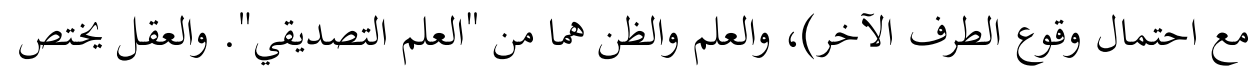

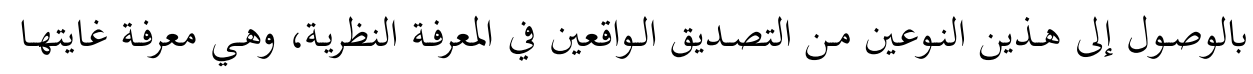

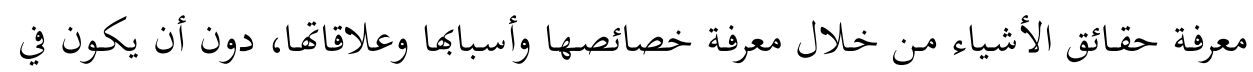

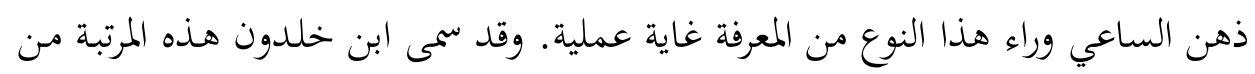

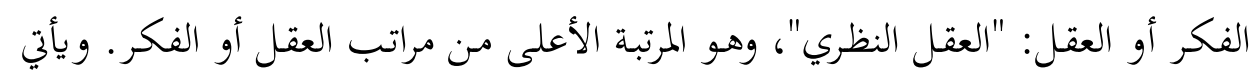

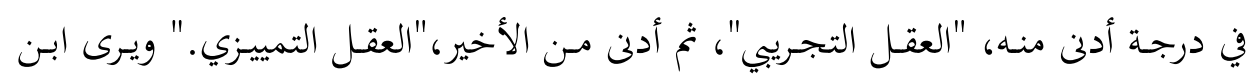

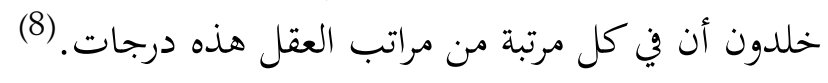

تم إن أفعال الإنسان التي يريد أن تتحقق في الواقع خارج الذهن، لا تتم إلا بالفكر

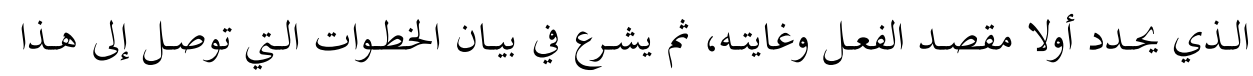

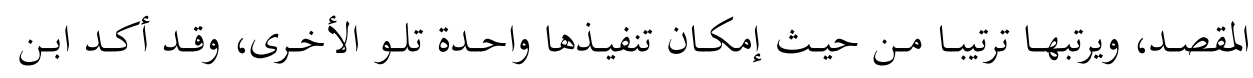

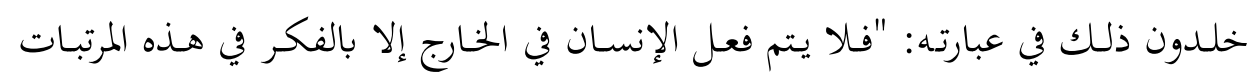

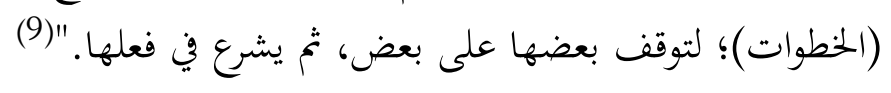

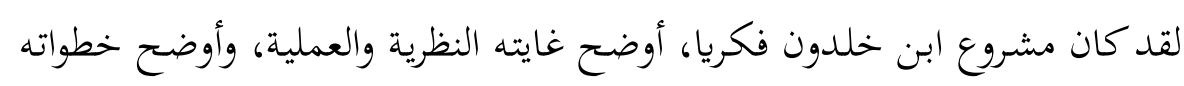

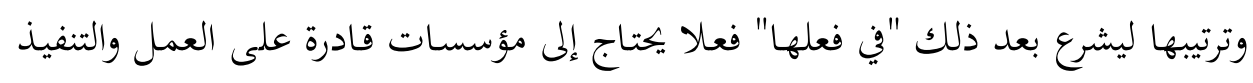
الإنجازه.

كان قصد ابن خلدون من مشروعه التجديدي تحقيق هدفين: الهدف الأول هدف

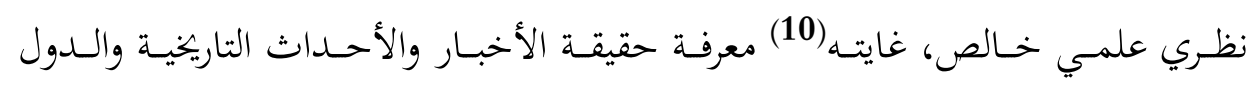

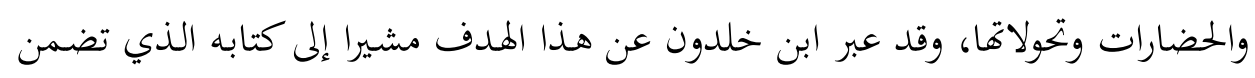

$$
\begin{aligned}
& \text { (7) المرجع السابق، ج3، ص1009. }
\end{aligned}
$$

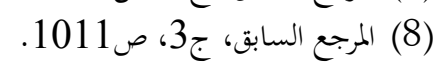

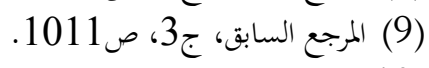

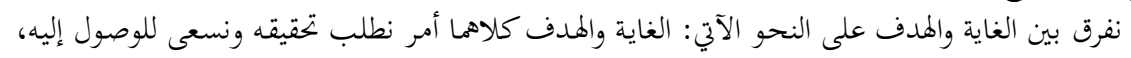

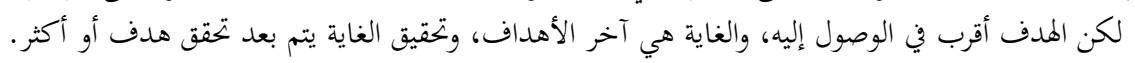


مشروعه الفكري، بقوله: "فاستوعب أخبار الخليقة استيعابا، وذلل مـن الحكمى النافرة

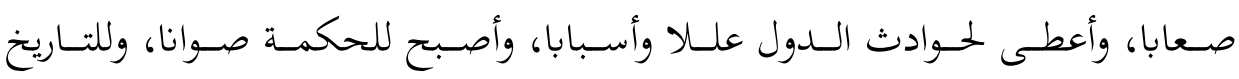

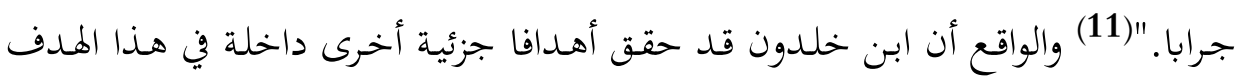

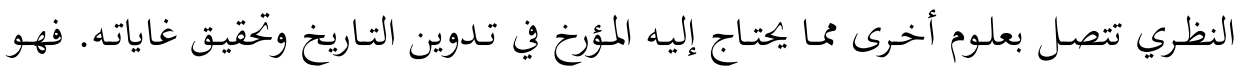

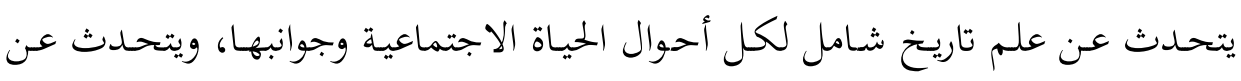

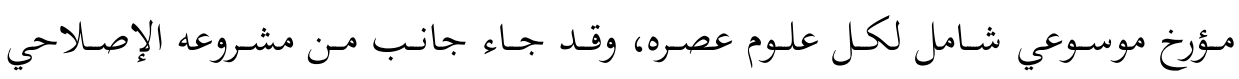

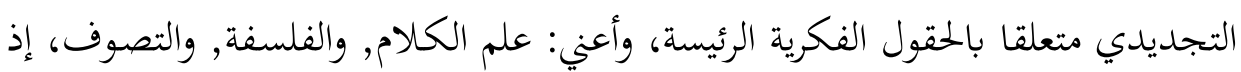
هي داخله ضمن عبارته: "النحل والمذاهب وسائر الأحوال" التي أوردناها آنفا. والهدف الثاني من مشروع ابن خلدون التجديدي هدف عملي، غايته أخذ العبرة

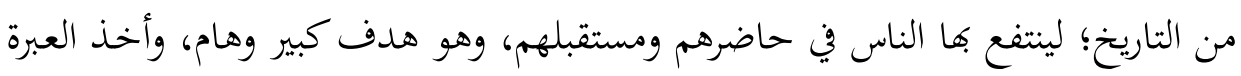

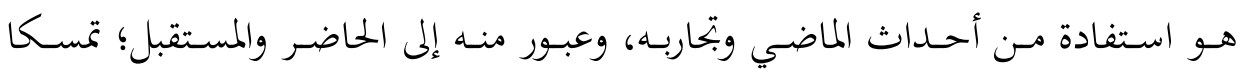

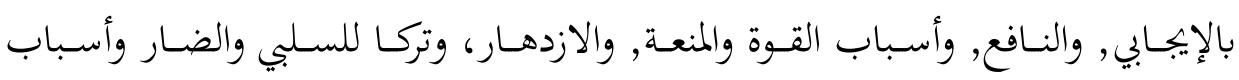

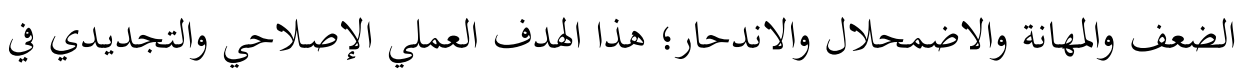

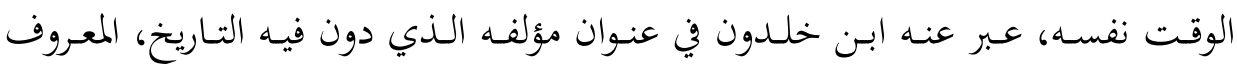

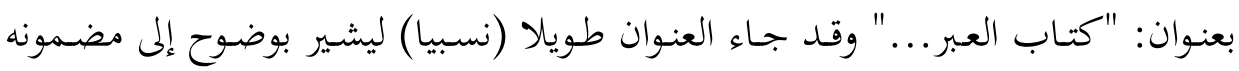

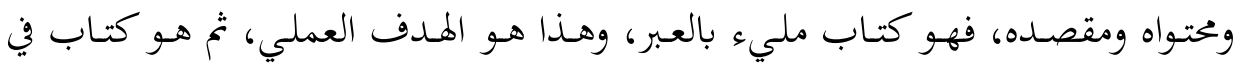

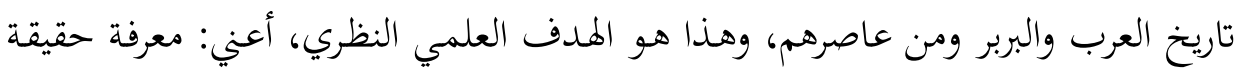

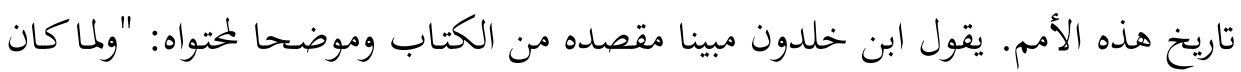

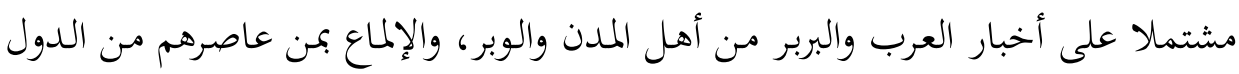

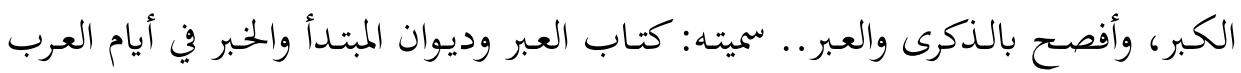
والعجم والبربر، ومن عاصرهم من ذوي السلطان الأكبر."(12)

$$
\begin{aligned}
& \text { المرجع السابق، ج1، ص286-287، صا201. } \\
& \text { المرجع السابق، ج1، ص287. }
\end{aligned}
$$


هكذا نرى أننا أمام مشروع فكري له غاية علمية صرفة، من توضيح لحقائق الأمور,

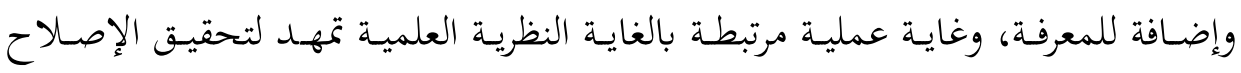

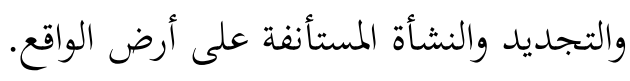

وقد انصـب الجههد التجديـدي لابـن خلـدون على عـدد مـن المجالات، هي تلكك

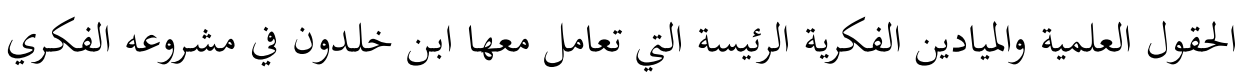

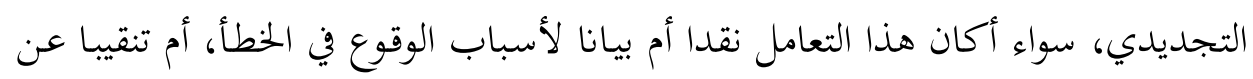

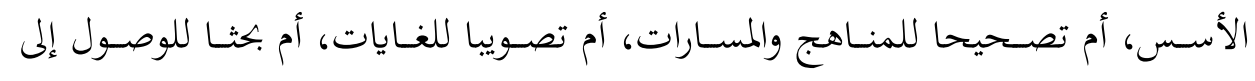
الثمرات. هذه الحقول العلمية أو الميادين الفكرية التي نرى أن المشروع الخلدوني ركز عليها هي: علم التاريخ، وعلم الكلام، والفلسفة، والتصوف. أمـا علم العمران وفلسفة التاريخ، فلم يكونا قبل ابن خلدون يمثلان علما يمكن أن

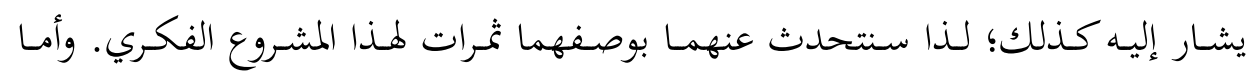

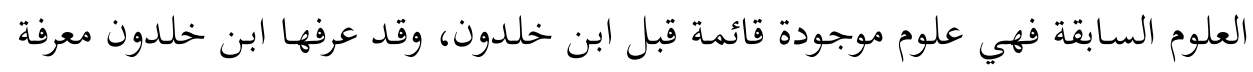

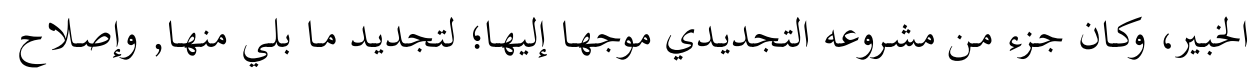
ما رآه فاسدا من أحوالها.

\section{ثانيا: التجديد في علم التاريخ:}

\section{1}

يرى ابن خلدون أن علم التاريخ علم كبير الأهمية لدى الأمم المختلفة، وأنه لجأ إلى

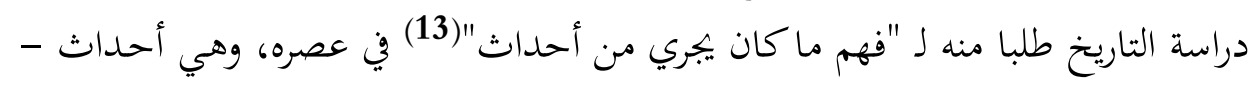

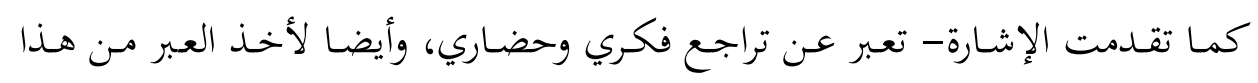

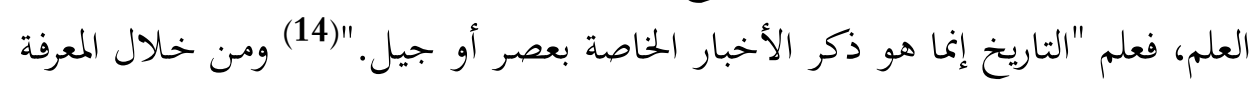

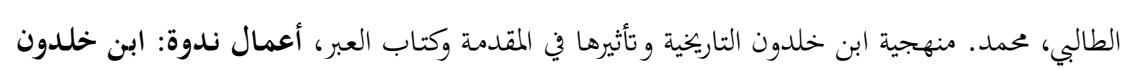

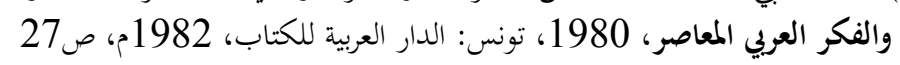

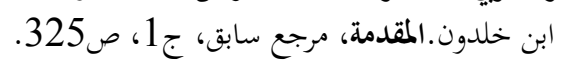


السياسية والاجتماعية والاقتصادية والفلسفية التي ينبغي توافرها في المؤرخ يمكن الوصول

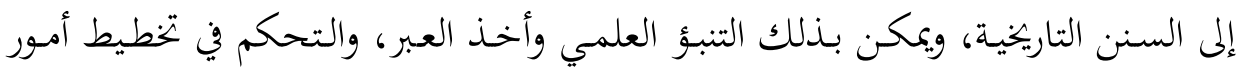
المجتمعات المستقبلية.

هذا ما ينبغي أن يكون عليه علم التاريخ، والمشكلة القائمة ترجع إلى طبيعة التاريخ؛

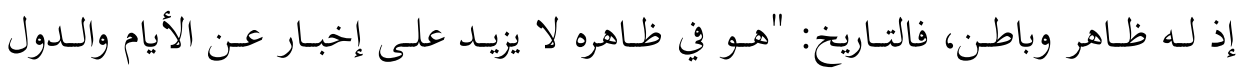
والسوابق من القرون الأول..."(15) وهو "في باطنه نظر وتحقيق وتعليل للكائنات ومباديها

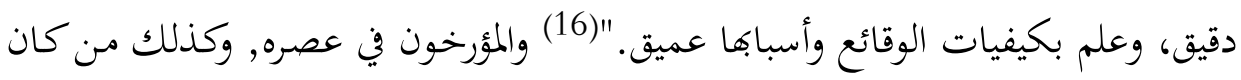

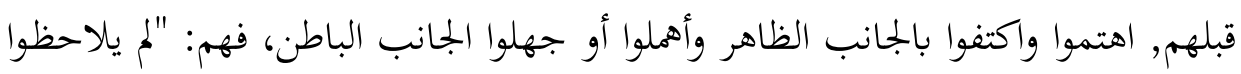

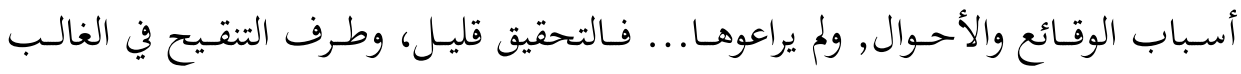
كليل... (17)"

نظر ابـن خلـدون نظرا دقيقـا متأنيـا في واقع التـدوين التـاريخي حتى عصـره ليحـدد

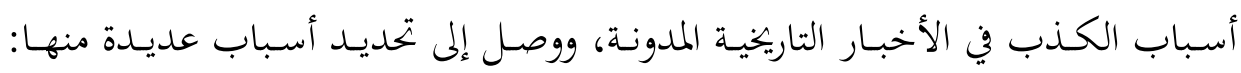

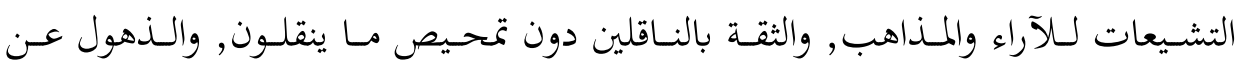

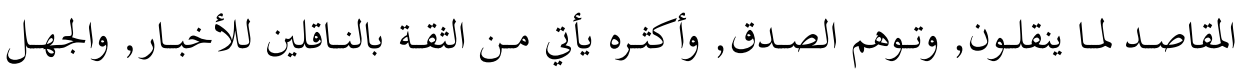

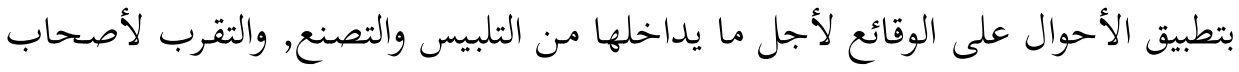

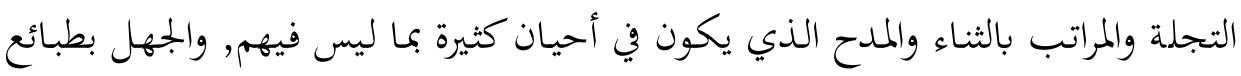

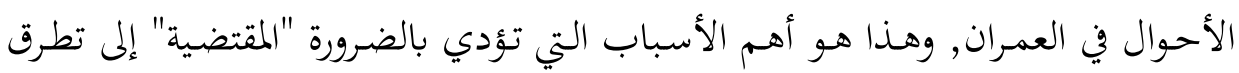

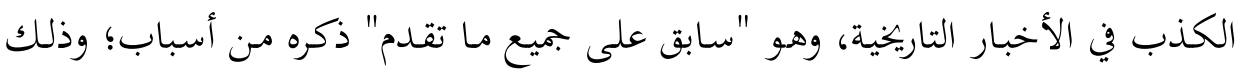
لشمول أحوال العمران لمعظم جوانب النشاط البشري، فكانت المعرفة به "أبلغ (السبل)

$$
\text { المرجع السابق، جابق، ج1، ع1، ص282، ص282. }
$$


في التمحيص من كل وجه يعرض،"(18) وهو "أحسن الوجوه وأوثقها في تمحيص الأخبار

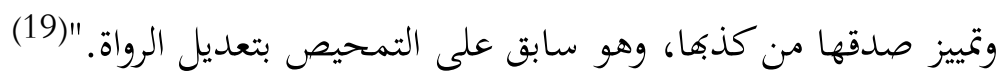

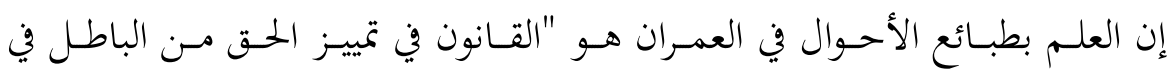

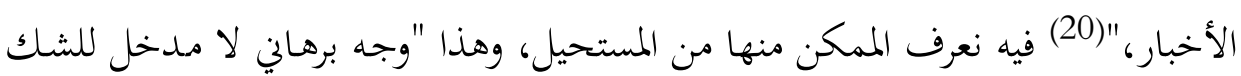
فيه؛"(21) أي أن تطبيق هذه المعرفة هو سلوك علمي دقيق، ونتائجه "برهانية".

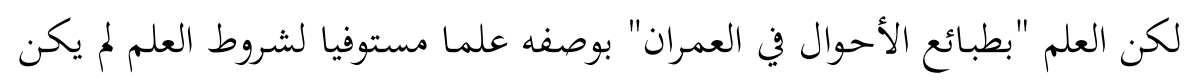

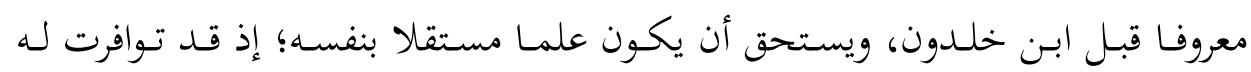

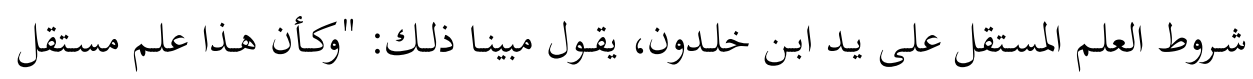

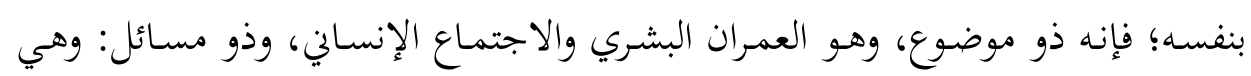

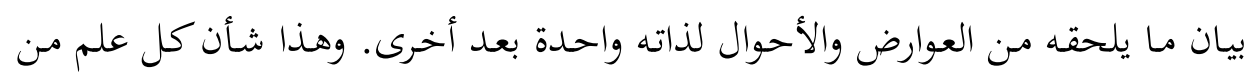
العلوم وضعيا كان أو عقليا. (22)

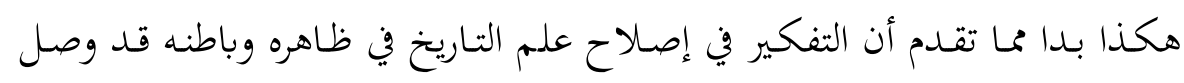
منتهاه على مرحلتين: المرحلـة الأولى: تشـخيص الـداء ببيـان أسباب الوقـوع في الخطـأ في تـدوين أخبـار

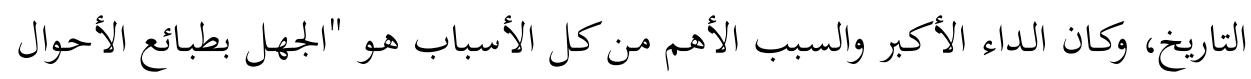

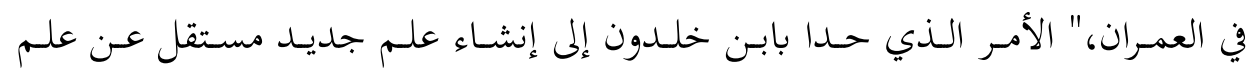
التاريخ، لكنه علم ضروري لمن يريد تدوين التاريخ.

\begin{tabular}{|c|c|}
\hline ، ص329. & \\
\hline ، ص330. & (19 \\
\hline المرجع السابق، & \\
\hline المرجع السابق، ج1، ص331. & \\
\hline المرجع السابق، ج1، ص331. & \\
\hline
\end{tabular}




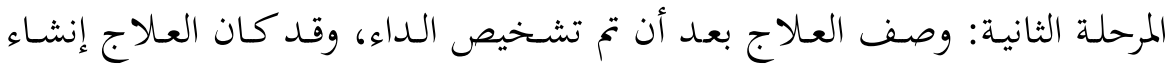

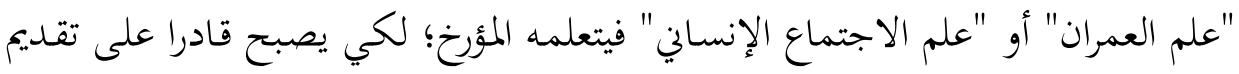
الحقيقة عن أحداث الماضي ووقائعه.

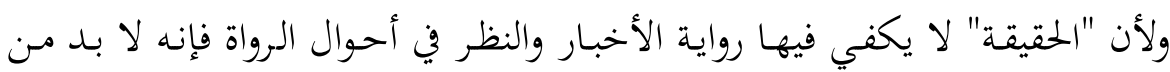

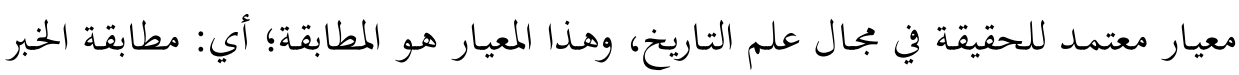

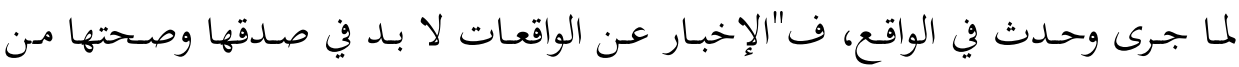

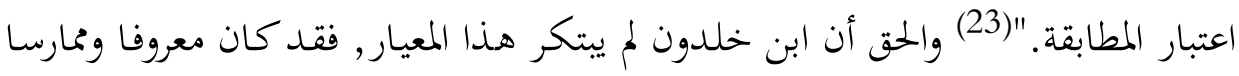

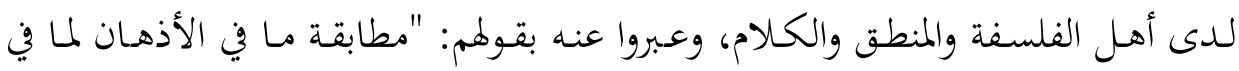

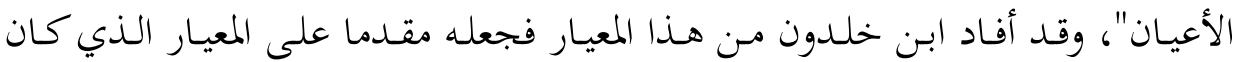

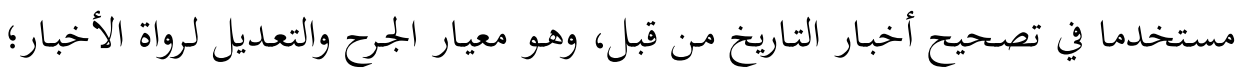

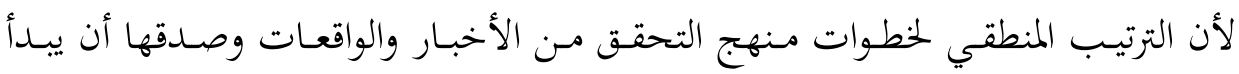

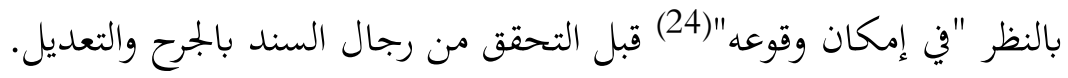

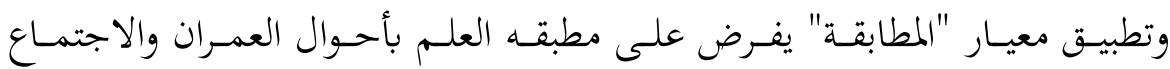

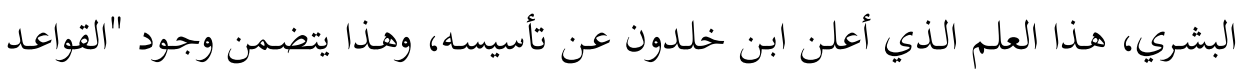

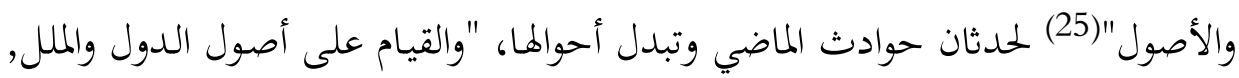

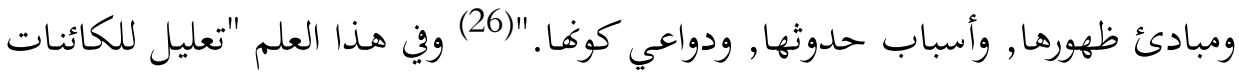

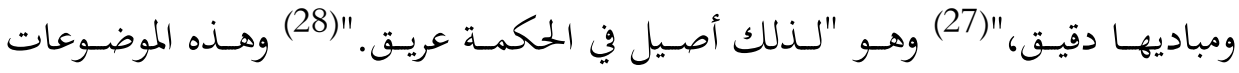

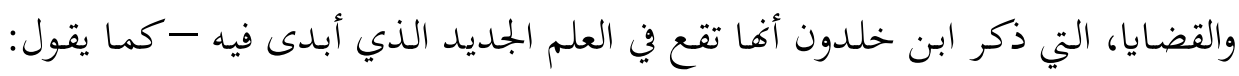

$$
\begin{aligned}
& \text { المرجع السابق، ج1، ص331. }
\end{aligned}
$$

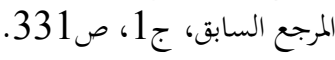

$$
\begin{aligned}
& \text { المرجع السابق، ج1، ص320. ع.3. } \\
& \text { المربع السابق، ج1، ص320. } \\
& \text { المرجع السابق، ج1، ص282. } \\
& \text { المربع السابق، ج1، ص282. }
\end{aligned}
$$


"لأولية الدول والعمران عللا وأسبابا"(29) تقع ضمن ما يعرف اليوم بـ: فلسفة التاريخ,

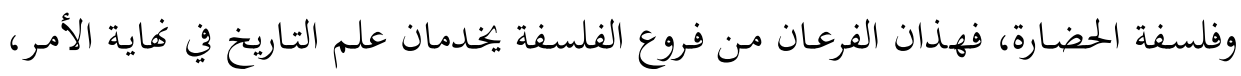

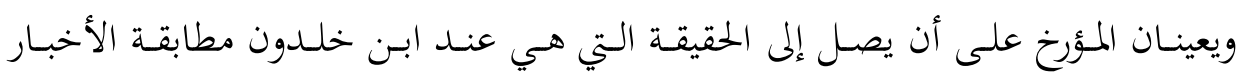
للوقائع والأحوال.

وهكذا سار ابن خلدون في مشروعه الفكري التجديدي من التفكير في إصلاح علم

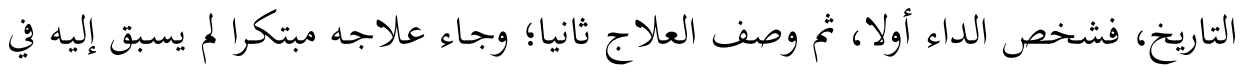

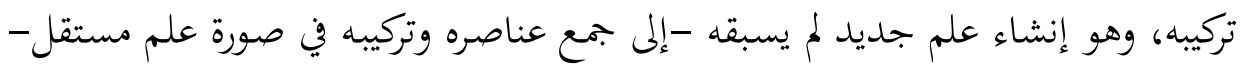

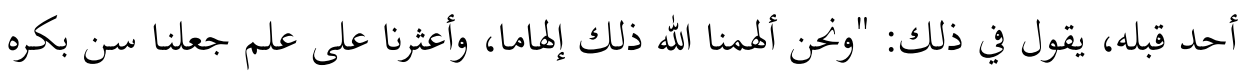
وجهينة خبره."(30)

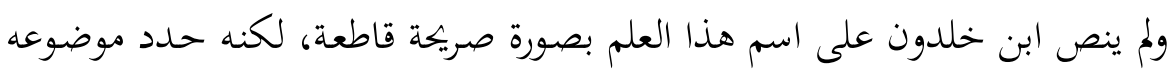

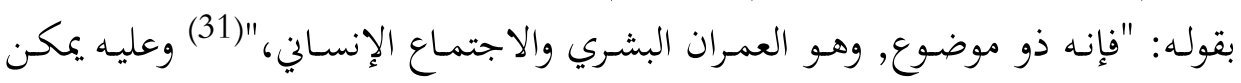

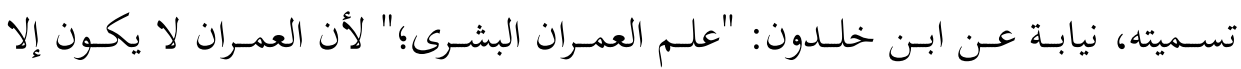

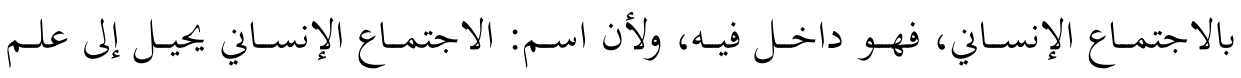

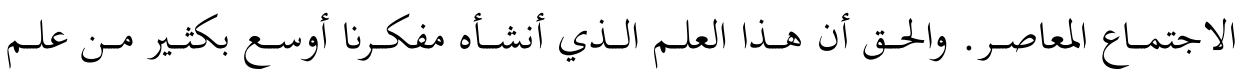

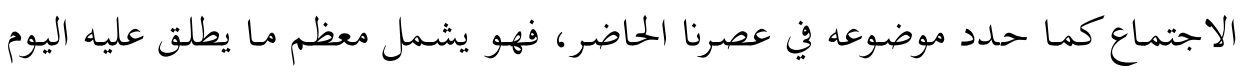

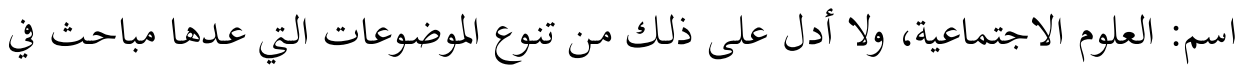

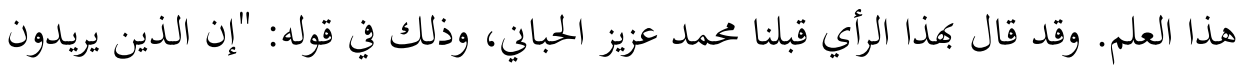

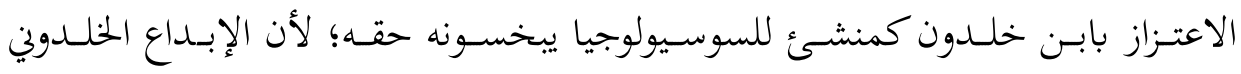

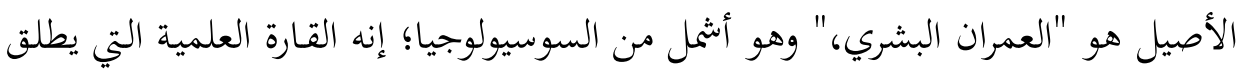
عليها اليوم اسم: علوم الإنسان."(32)

المرجع المابق، جابق، ج1، ص334. ص285.

الحابباي، حمد عزيز. تعقيب على الندوة، أعمال ندوة ابن خلدون، الرباط: منشورات كلية الآداب والعلوم 
ويمكـن القول باطمئنـان تام: إن عـلاج ابن خلـدون المبتكـر لإصـلاح أوضـاع علم

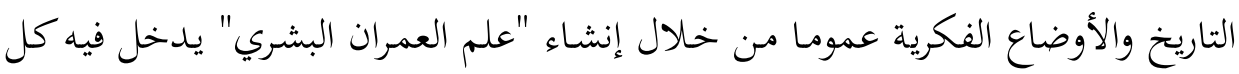
من: علم الاجتماع, وفلسفة التاريخ, وفلسفة الحضارة.

\section{2. - جوانب التجديد في علم التاريخ:}

\section{أ. التجديد في علم التاريخ نفسه:}

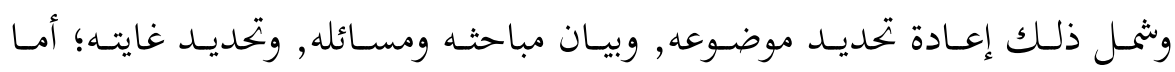

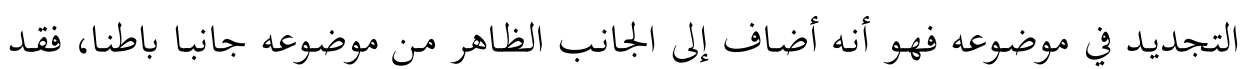

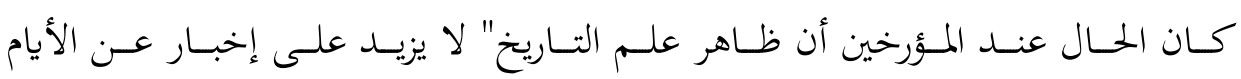

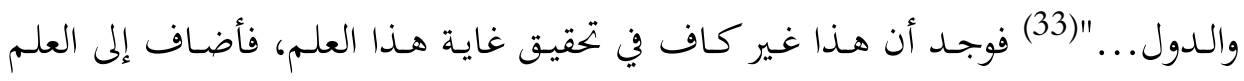

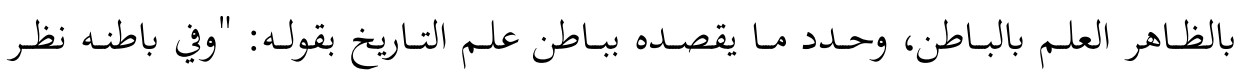

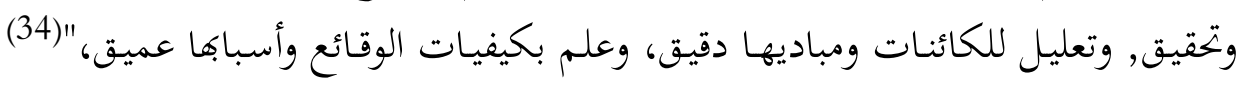

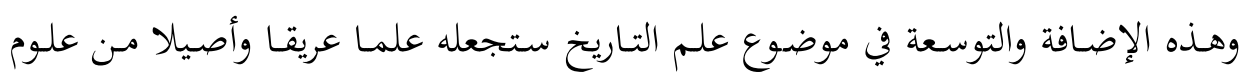
الحلكمة، يقول: "فهو لذلك (جانب الباطن) أصيل في الحكمة عريق، وجدير بأن يعد في علومها وخليق." (35)

هذه عبارات تستحق وقفة للتأمل والتحليل؛ لما تنطوي عليه من نظرة جديدة لعلم

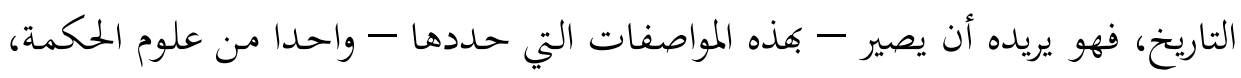
بـل علمـا أصيلا فيها، لا أن يضـاف إلى قائمـة هـذه العلوم بجاملة أو جزافـا، وإنما لأنسان

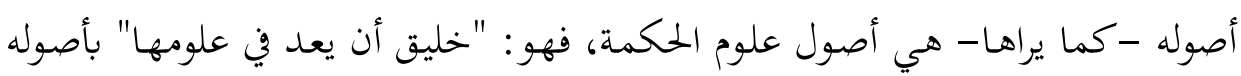

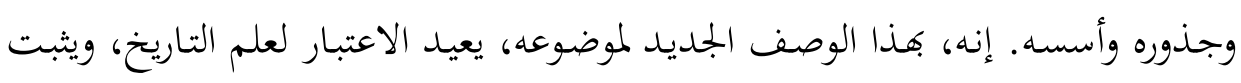
نسبه وشجرة عائلته التي ينتمي إليها، وهي علوم الحكمة.

$$
\begin{aligned}
& \text { ابن خلدون. المقدمة، مرجع سابق، ج1، ص282، ص282. }
\end{aligned}
$$

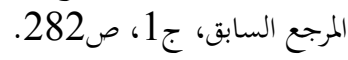

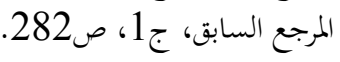


ونرى أن خلدون قال ذلك وهو على وعي كامل بدلالة ما يقوله، وهو وعي ينطوي

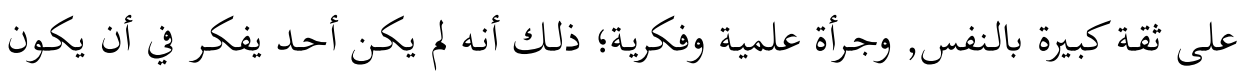

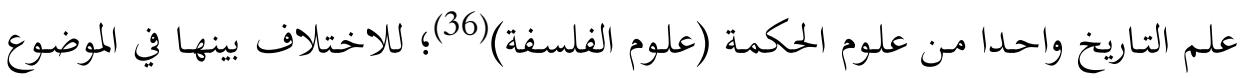

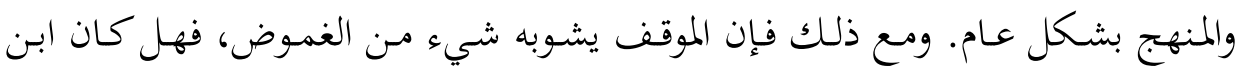

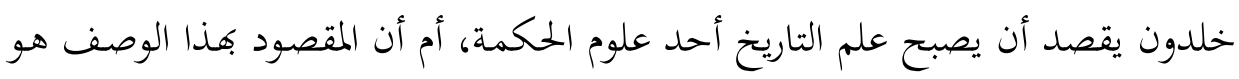

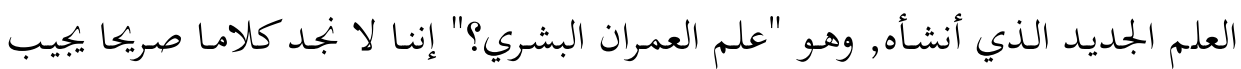

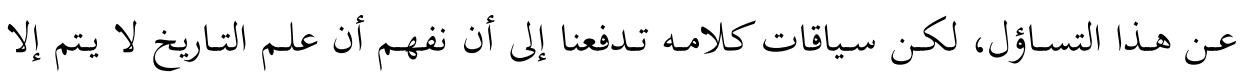

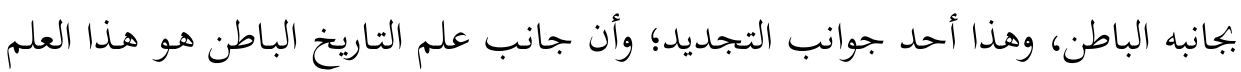

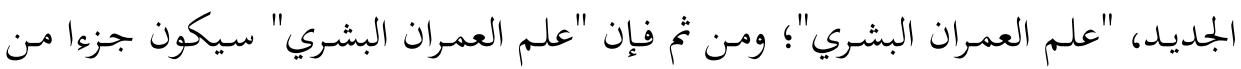

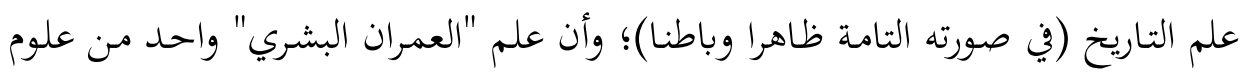

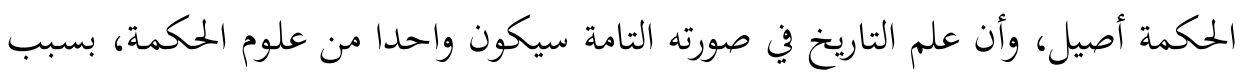
جزئه الباطن.

والواقع أن جعل علم التاريخ واحدا من علوم الحكمة كان طموحا عند ابن خلدون على المستوى النظري؛ ذلك أنه في تدوينه للتاريخ كان تقليديا، فقد رأى أغلب علب الباحثين

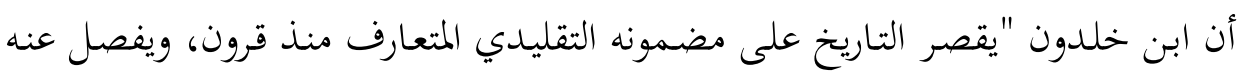

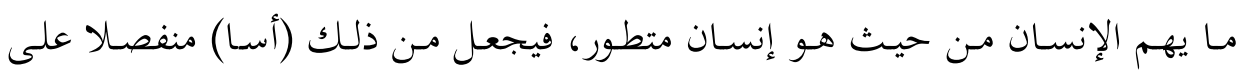

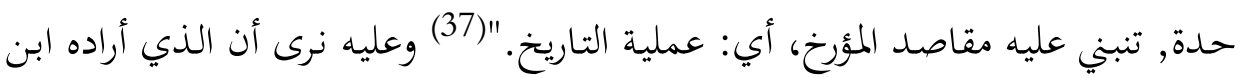

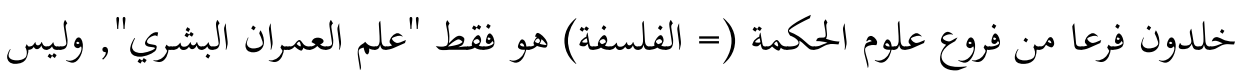
علم التاريخ.

لفظة فلسفة تعني: محبة الحكمة. ولفظ سوفيا Sophia ليس يونانيا (كما اكتشفناه لأول مرة في كلام

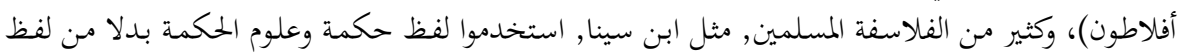

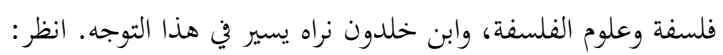

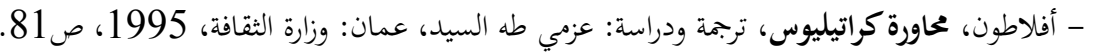

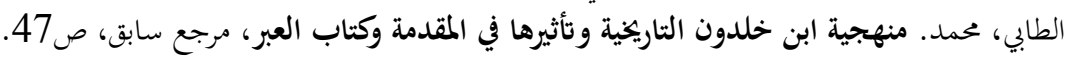


إن "علم العمران البشري" بالصورة التي وضعها ابن خلدون ووصفها في المقدمة هو

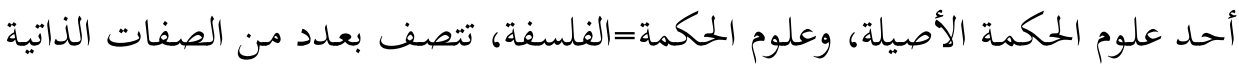

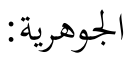

أولها: أفها بحث عن حقائق الأشياء؛ فالفلسفة غايتها الوصول إلى الحقيقة في الأمور

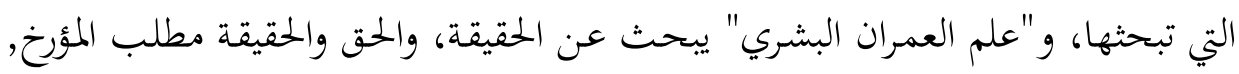

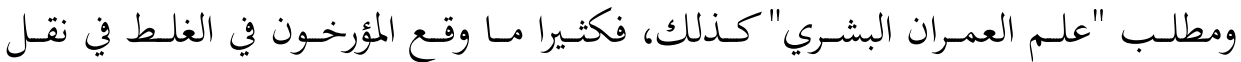

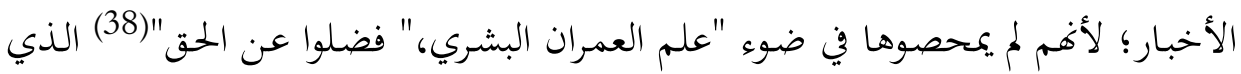

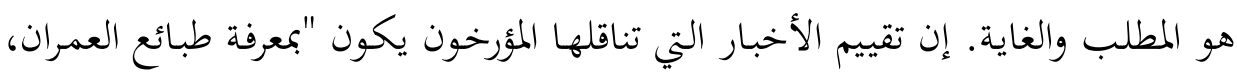

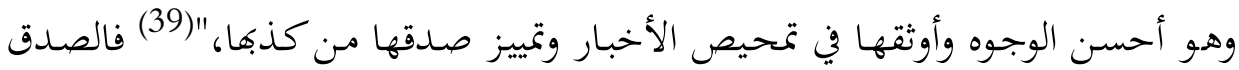

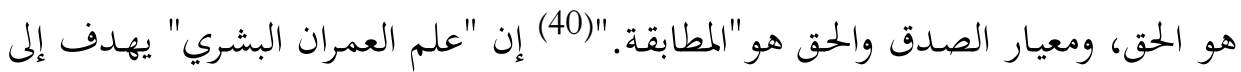

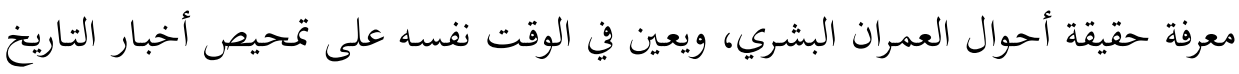

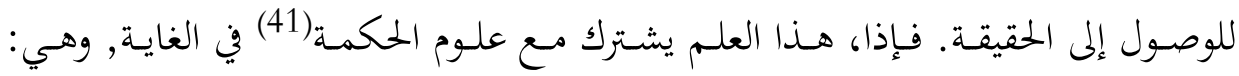

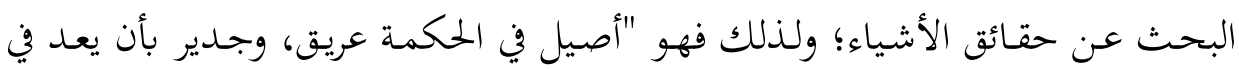
علومها وخليق. "(42)

ثانيها: التعمق في البحث، وتعني أن الباحث عن الحقيقة لا يكتفي بالوقوف على

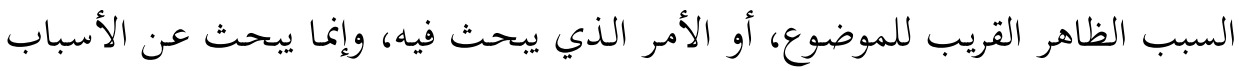

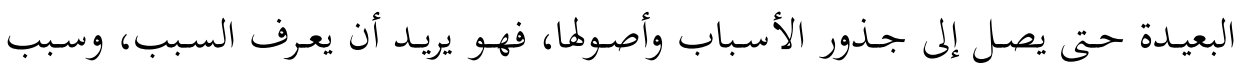

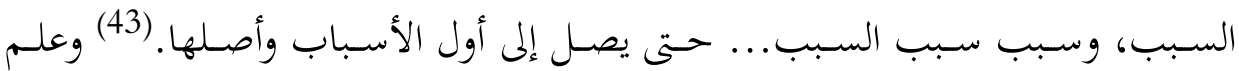
العمران البشـري، وهـو باطن علم التـاريخ فيـه هـذه الخصيصـة، فهـو : "تعليل للكائنـات

$$
\begin{aligned}
& \text { ابن خلدون. المقدمة، مرجع سابق، ج1، ص231، ص230. }
\end{aligned}
$$

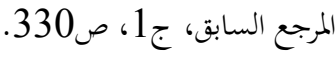

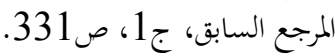

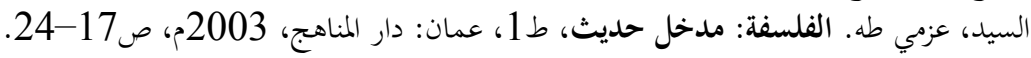

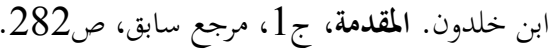

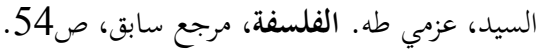


ومباديها دقيق، وعلم بكيفيات الوقائع وأسبابها عميق، فهو للذلك أصيل في الحكمة

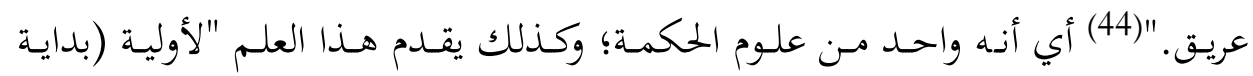

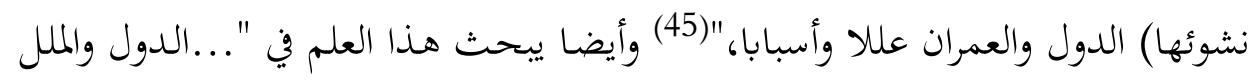

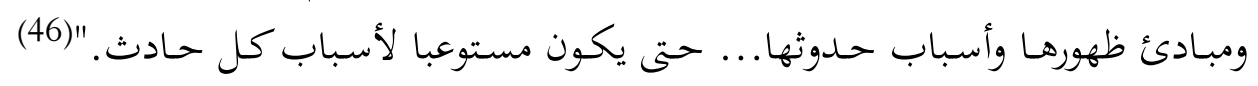

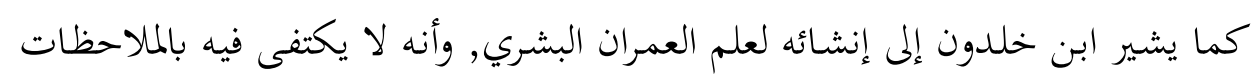

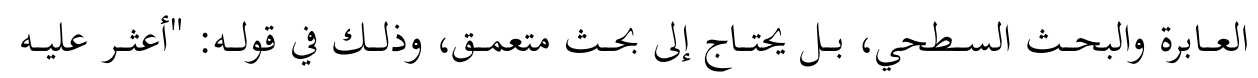
البحث, وأدى إليه الغوص."(47)

ثالثها: النقــ والتعليل والتفسير، وهـذه الأمور معروفة في علوم الحكمة (الفلسفة), وهي موجودة في "علم العمران البشري." فأول ما وصف بـه ابن خلدون هذا ولندا العلم هو

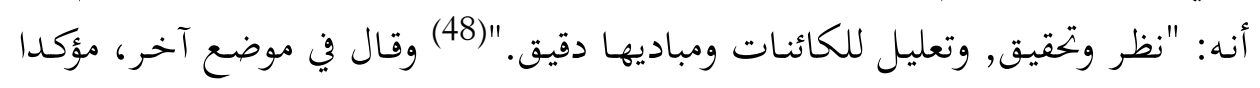

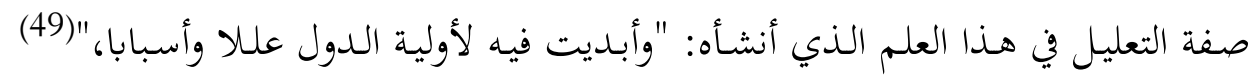

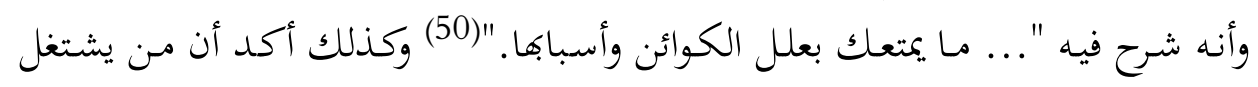

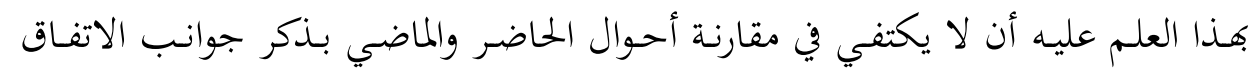

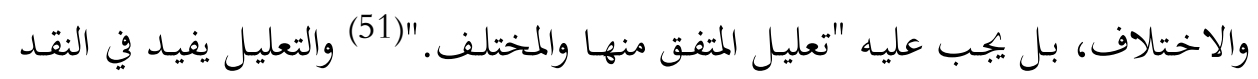

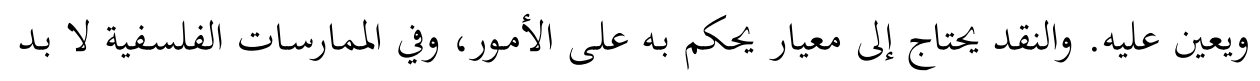

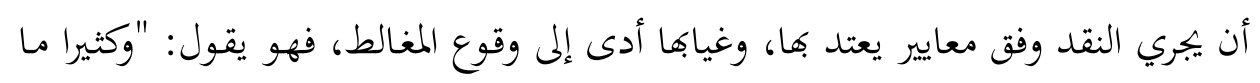

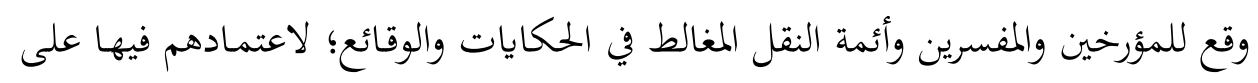
مجرد النقـل غثـا أو سمينـا، لم يعرضـوها على أصسول (وهـذه محارسـة نقديـة), ولا قاسـوها

$$
\begin{aligned}
& \text { ابن خلدون. المقدمة، مرجع سابق، ج1، ص282، ص282. } \\
& \text { المرجع السابق، ج1 إن، ص285. }
\end{aligned}
$$

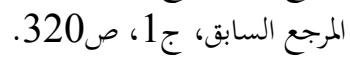

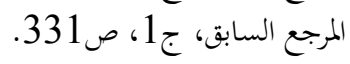

$$
\begin{aligned}
& \text { المرجع السابق، ج1، المبان، ص282، ص285. } \\
& \text { المرجع السابق، ج1، صلم ص285. }
\end{aligned}
$$

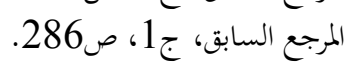

$$
\begin{aligned}
& \text { المرجع السابق، ج1، ص320، }
\end{aligned}
$$


بأشباهها، ولا سـبروها بمعيـار الحكمهة ..."(52) وابـن خلمدون لا يـرى في علم العمـران

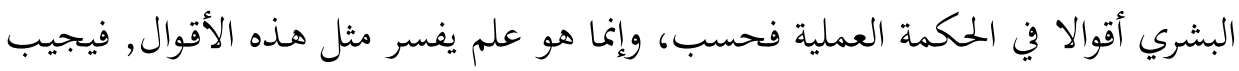

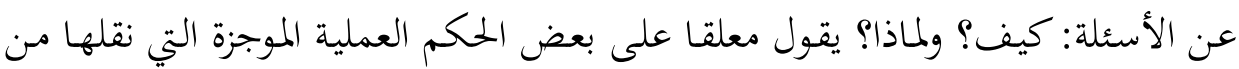

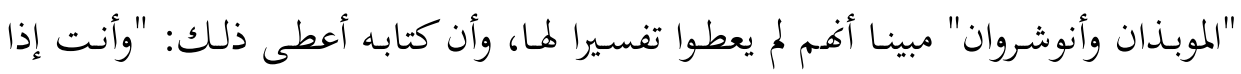

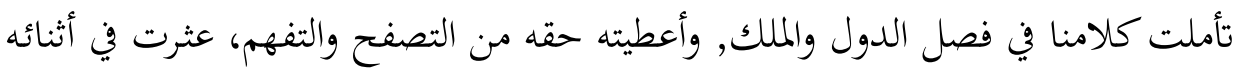

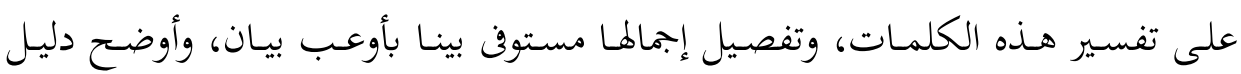
وبرهان؛"(53) وهذا ما تقوم به الفلسفة.

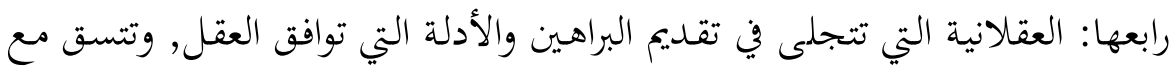

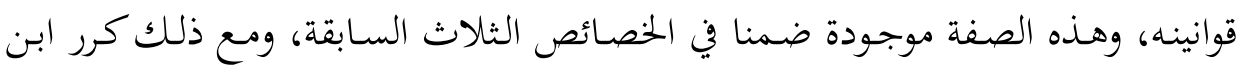

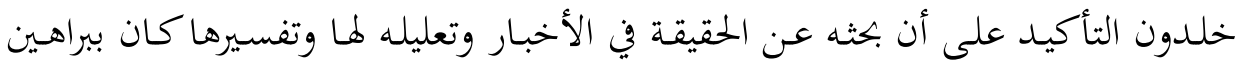

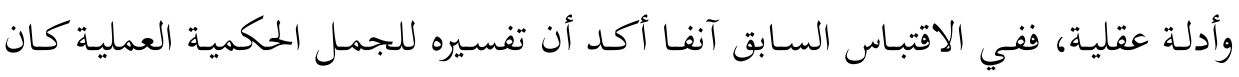

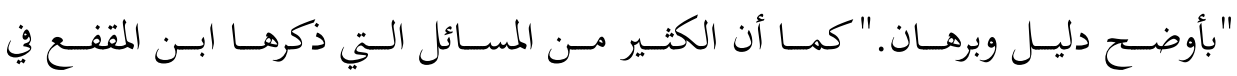

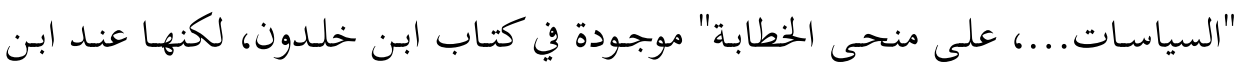

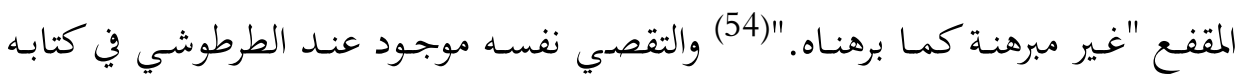

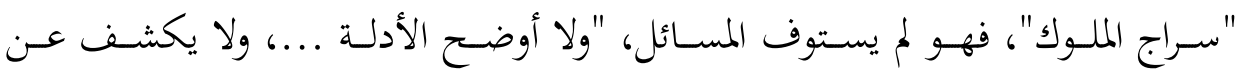

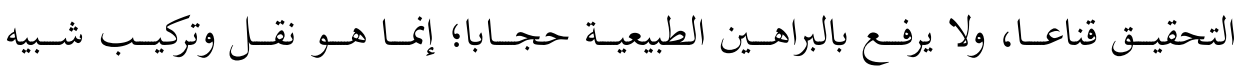
بالمواعظ." (55)

لهذه الأقوال وغيرها في وصف تمسك ابن خلدون -في علم العمران البشري- بالأدلة

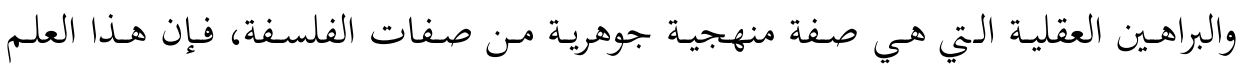

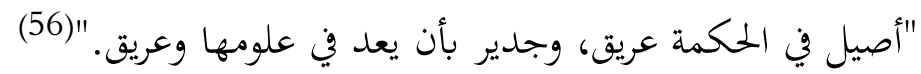

$$
\begin{aligned}
& \text { المرجع السابق، ج1، ص291. }
\end{aligned}
$$

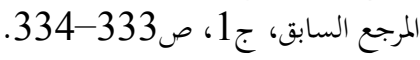

$$
\begin{aligned}
& \text { المرجع السابق، ج1، ص334. ص334. } \\
& \text { المربع السابق، ج1، ص334، ص334. } \\
& \text { المرجع السابق، ج1، ص282. صلر. }
\end{aligned}
$$


وبعـد، فإنــا نـرى مـا قـدمناه مـن أدلـة آنفـا، كافيـة في إثبـات أن ابـن خلـدون كـان

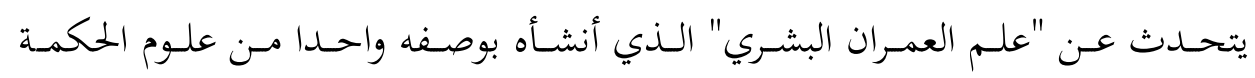
(الفلسفة) الأمر الذي سنجد انعكاساته في موقفه من كل من: علم الكامر , والفلسفة.

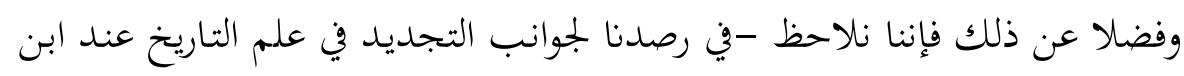
خلـدون- أن إضـافته للجانب البـاطن قد استلزم إضـافة مباحث ومسـائل جديـدة لعلم

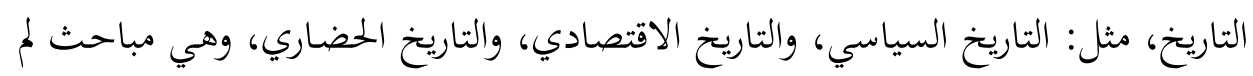

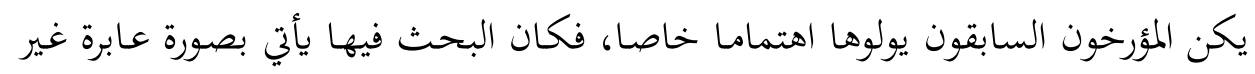
مقصودة لذاها.

أما بتحيد ابن خلدون في غاية علم التاريخ، التي ينبغي أن يضعها المؤرخ نصب عينيه

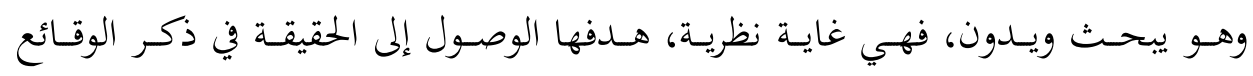

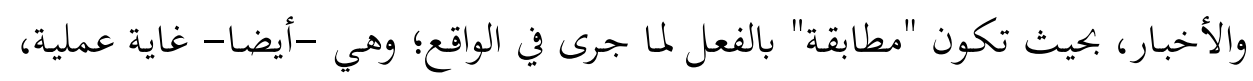
هدفها استخلاص "العبر" التي بتعلنا نستفيد من بتحارب الماضي في حاضرنا ومستقبلنا.

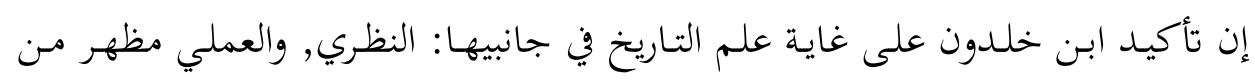

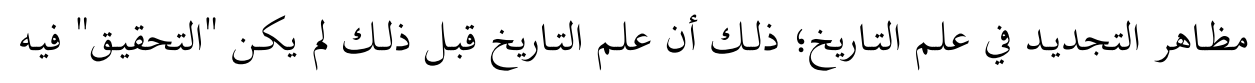

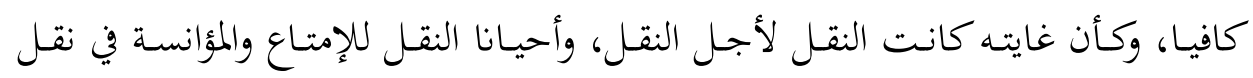

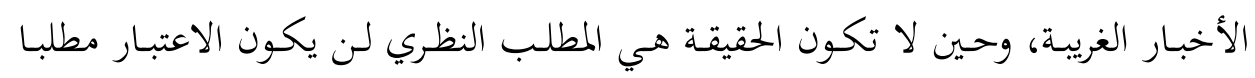

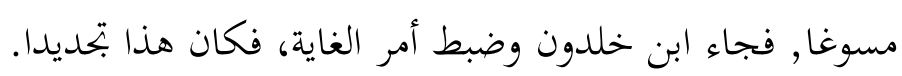

\section{ب. إصلاح منهج البحث في علم التاريخ:}

وقد استوفى العديد مس الباحثين في فكر ابن خلدون هذه المسألة دراسة؛ ولذلك

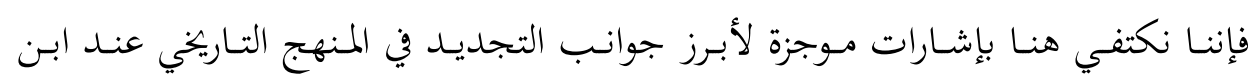
خلدون.

فهو يؤكس على أن المنهنج غايته مسـاعدة المؤرخ في الوصول إلى الحـق، فإنه بـدون

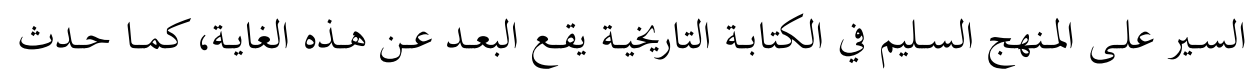




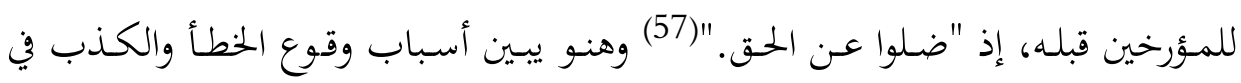

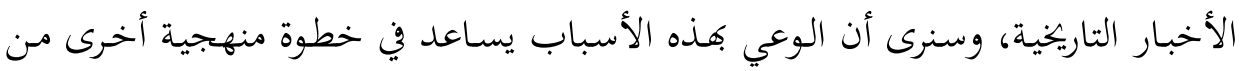
خطوات المنهج الموصل إلى الحق، وهي نقد الأخبار وتمحيصها.

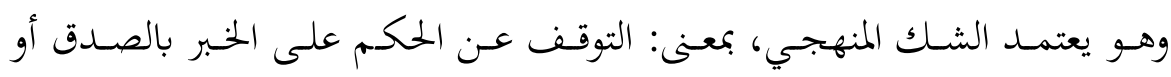

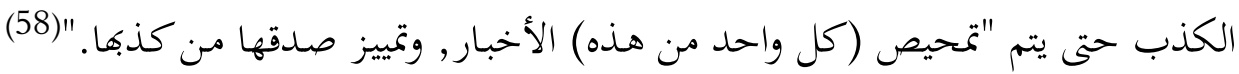

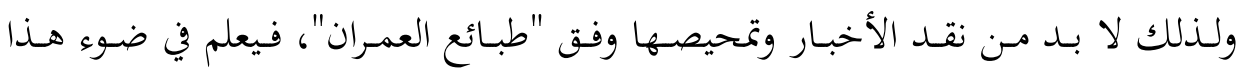

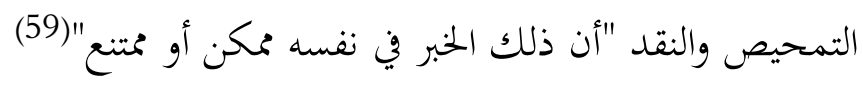
تم إنه ينقد الرواة وفقا لطرق وأساليب الجرح والتعديل التي مارسها علماء الحمديث

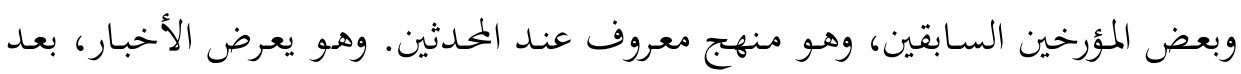

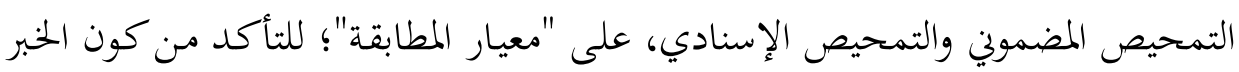

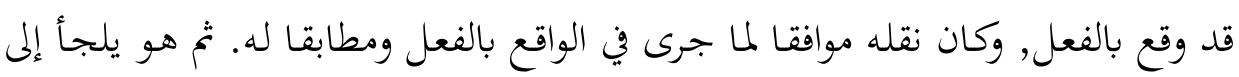

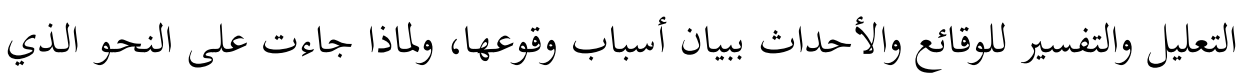

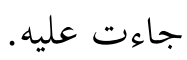

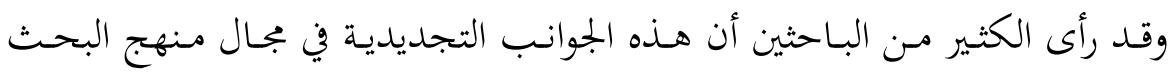

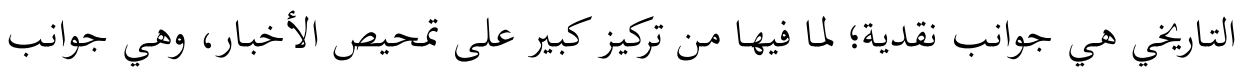

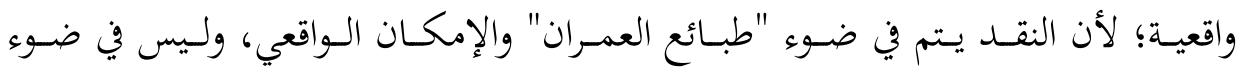

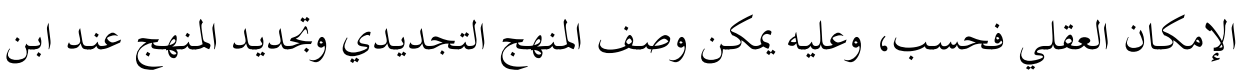
خلدون بأنه واقعي نقدي. (60)

$$
\text { المرجع السابق، ج1، ص1330، ص291. }
$$

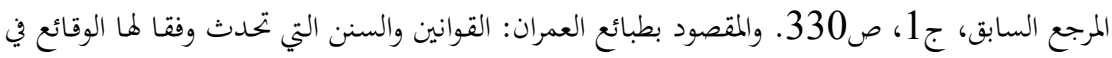

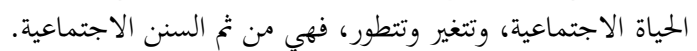

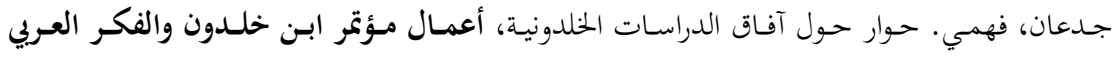

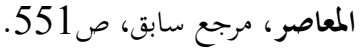




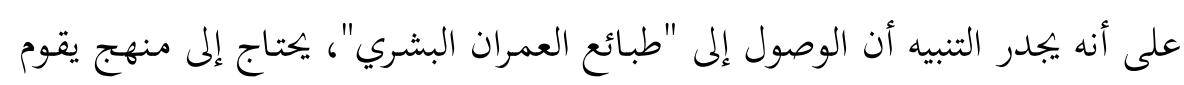

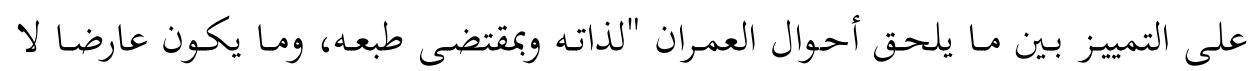

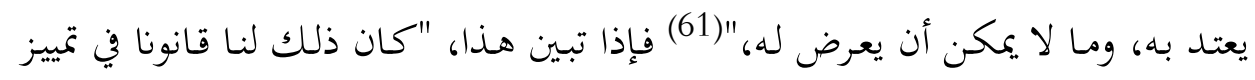

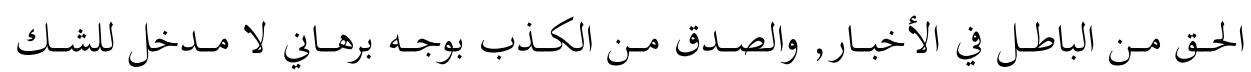

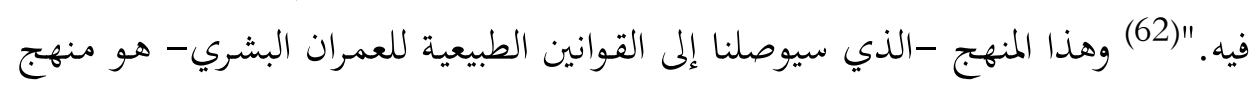

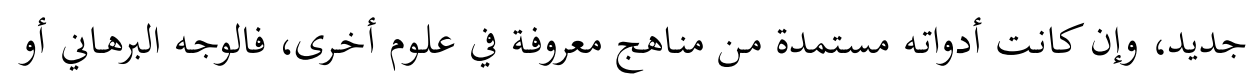

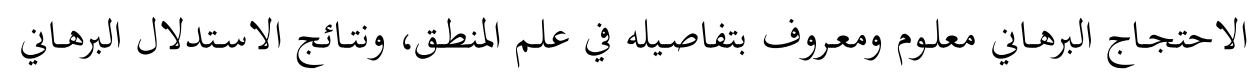

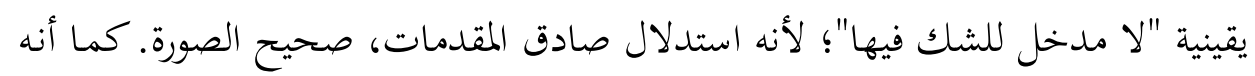

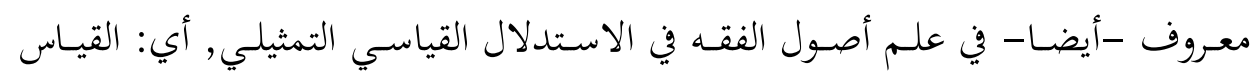

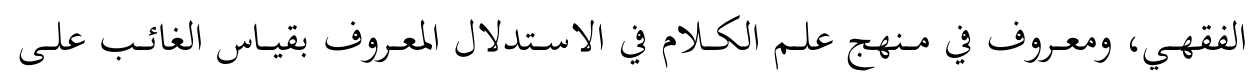

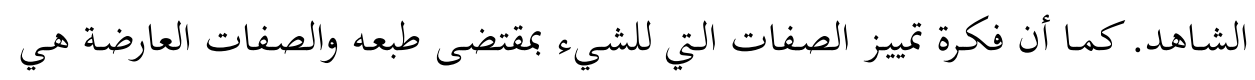

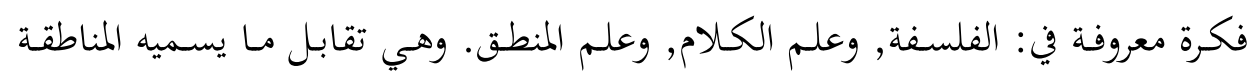

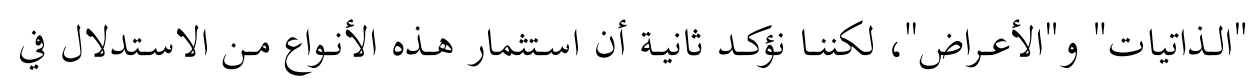

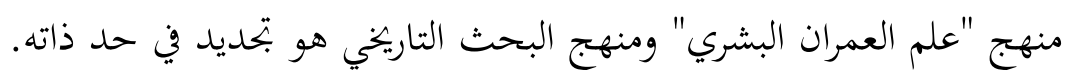
والحق أن صفة أخرى اتصف بها منهج ابن خلدون، وهي واضحة في كل مل ما لما ذكرناه

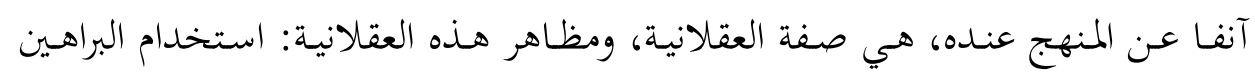

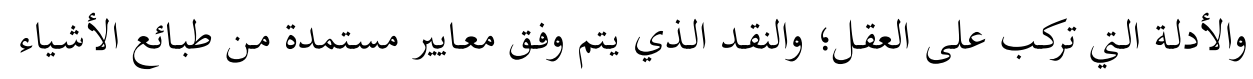

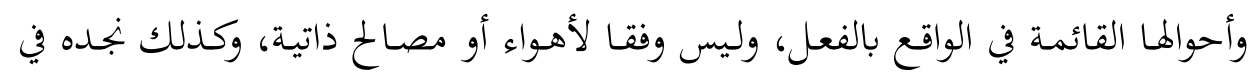

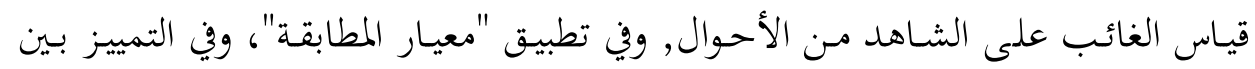

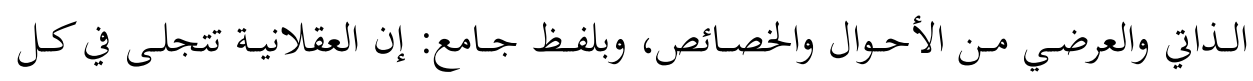

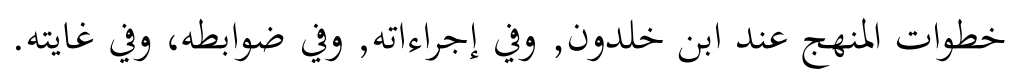

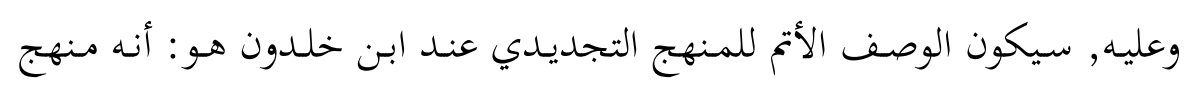

عقلاني نقدي واقعي، وهذه الأوصاف الثلاثة متسقة متكاملة لا تعارض بينها.

$$
\begin{aligned}
& \text { ابن خلدون. المقدمة، مرجع سابق، ج1، ص331. }
\end{aligned}
$$

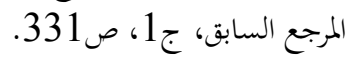




\section{ج. تأصيل علم التاريخ وتقعيده:}

هذا الجانب هو ما يعرف اليوم باسم فلسفة التاريخ وفلسفة الحضارة. وابن خلدون

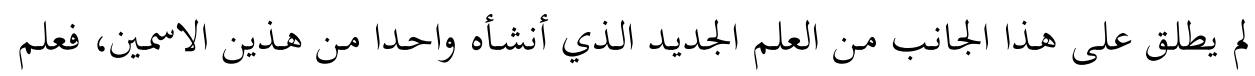

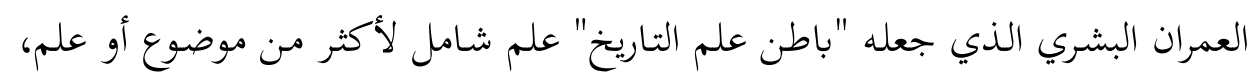

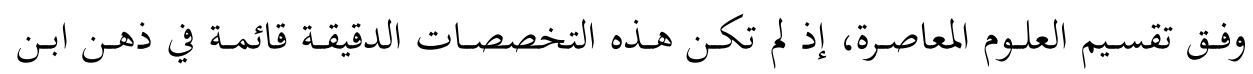
خلدون، وكانت نظرته أن هذه الجوانب تتكامل في هذا العلم الجلديد الشامل؛ ولهذا آثرنا

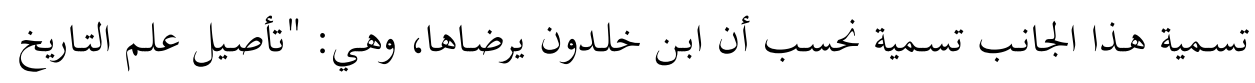

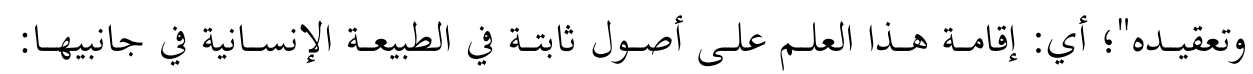

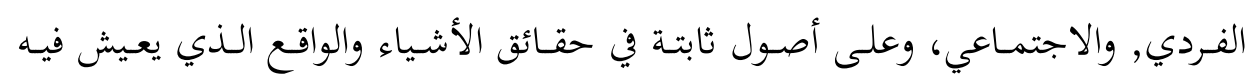
الإنسان.

وقد أشار ابن خلدون إلى أهمية وضع القواعد العامة والقوانين التي يرى أهـا تحكم

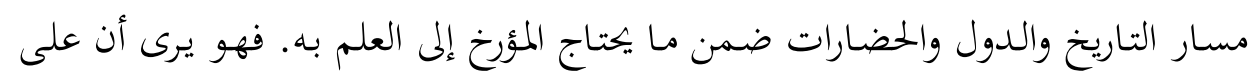

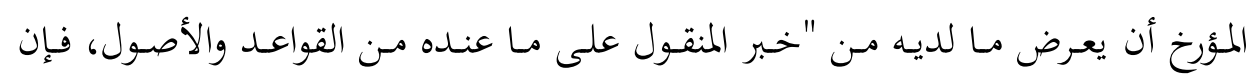

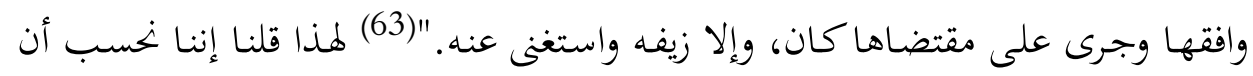

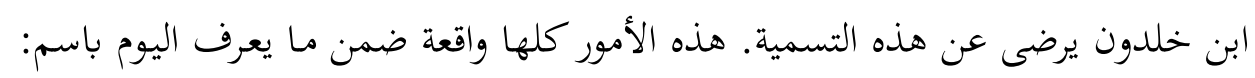
فلسفة التاريخ, أو فلسفة الحضارة.

ويرى الجابري أن مقدمة ابن خلدون كانت متميزة؛ "لأهـا لم تكن فقط مقدمة لـ " تأسيس" وجهة نظر أو بيـان مسنهج، بل كانت أكثر مـن ذلك، مقدمـة لتأسيس علم

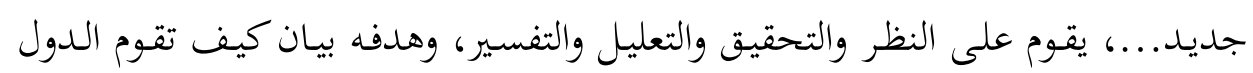

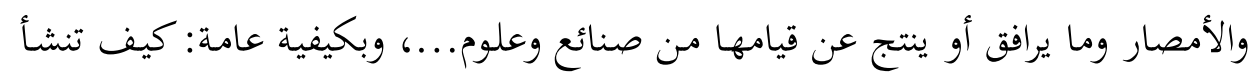

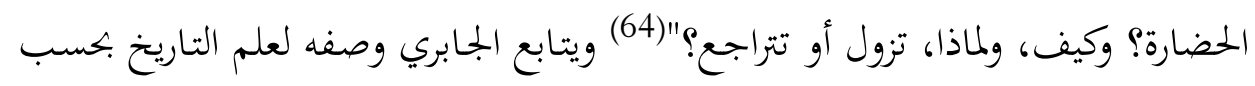

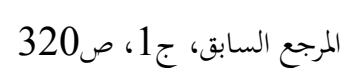

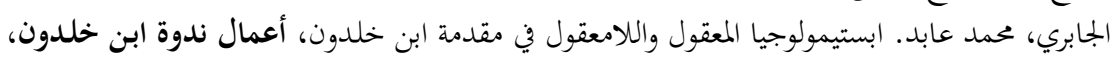

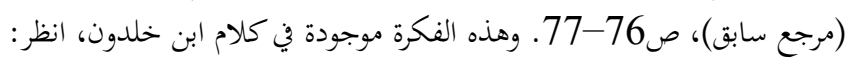


تصور ابن خلدون مشيرا إلى المبادئ والأسس بقوله: "هذا التصور الجلديد الواسع الشامل

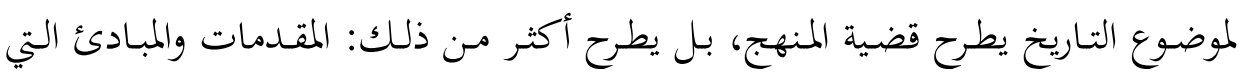

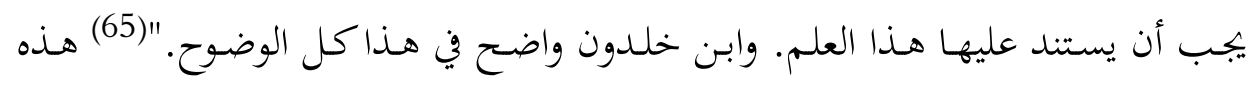

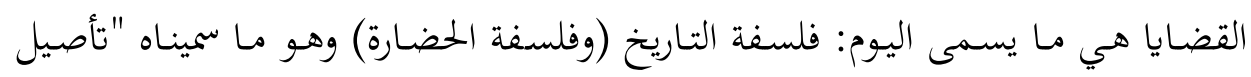

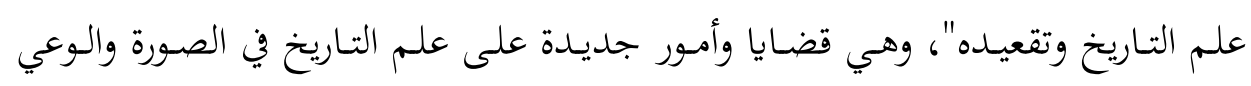
اللذين وجدا عند ابن خلدون، وكان هدفه من ذلك إصلاح علم التاريخ وبتحيده. ويمكن استخلاص مجموعة مـ المبادئ والأسس التي قدمها ابن خلدون، والتي تعد مادة أساسية لما يعرف اليوم بفلسفة التاريخ وفلسفة الحضارة.

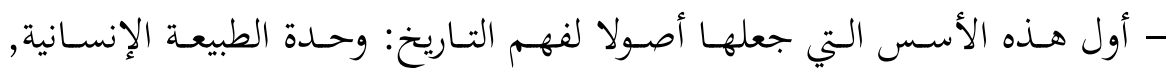

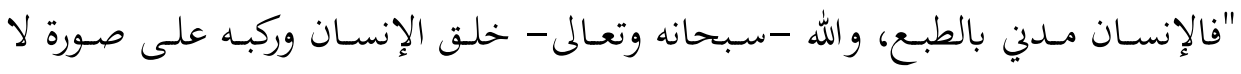

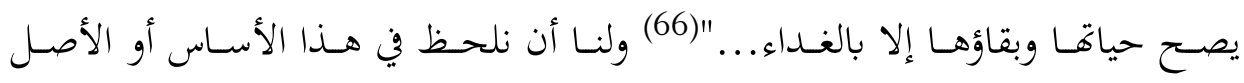

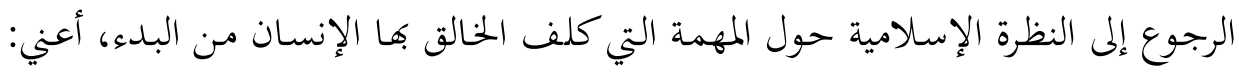
الخلافة في الأرض وعمارةتا.

- الأساس الثاني هو: ضرورة الملك، فإذا وجد الاجتماع الإنساني وجد الملك، فهذا

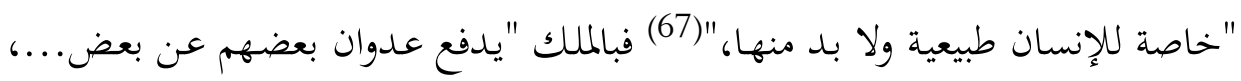

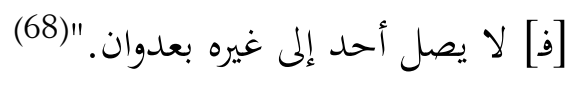

- الأساس الثالث يرجع إلى: طبيعة المكان الذي يعيش فيه الإنسان، فلطبيعة المكان أثر في أحوال العمران، فهذه الأرض أقاليم مختلفة, تختلف طبائع كل منها، وتها، وتؤثر طبيعة

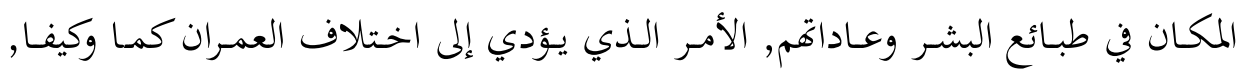
يقول ابن خلدون: "ونحن نرى بالمشاهدة والأخبار المتواترة أن الأول والثاني مـن الأقاليم

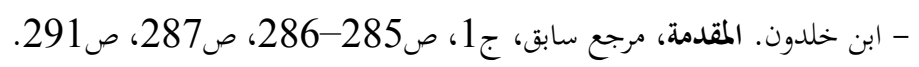

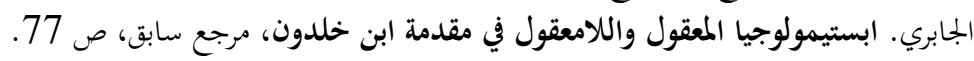

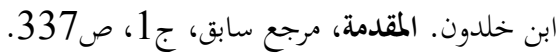

$$
\text { المرجع السابق، جابق، ج1339، ص339. }
$$


المعمورة أقل عمرانا مـا بعدها، ...، وأمم هذين الإقليمسين وأناسيهما ليست لهم الكثرة

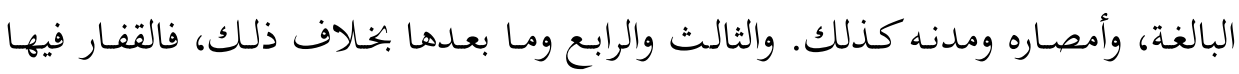

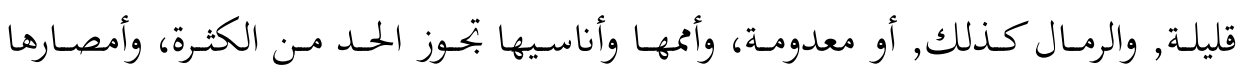
ومدها بتحاوز الحد عددا...، وقد ذكر كثير من الحكماء أن ذلك لإفراط الحر وقلة ميل الشمس فيها عن سمت الرؤوس."(69) ومكاون

- الأساس الرابع: وجود سنن للاجتماع البشري في جميع أوجـه النشاط الإنساني،

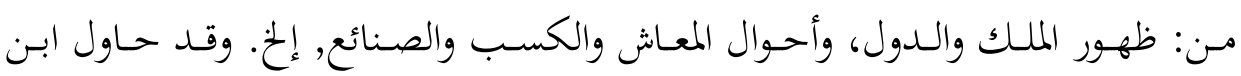
خلدون التدليل على وجود هذه السنن من خلال الكشف عن عن عدد كبير منها, وتوضيح

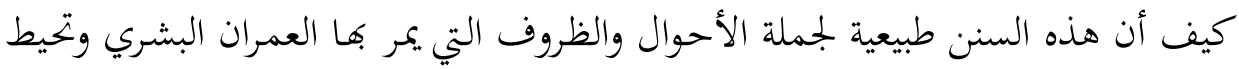
به، والباب الثاني من المقدمة بيان لذلك.

- الأسـاس الخـامس: يؤكسد وجـود أسباب لحسدوث الأحسوال وتغيرهـا في الاجتمـاع

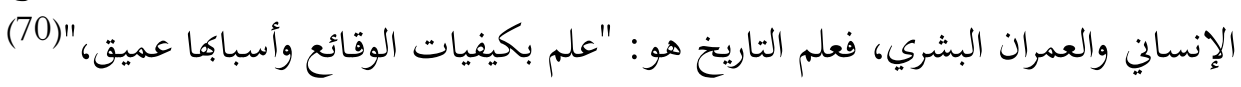

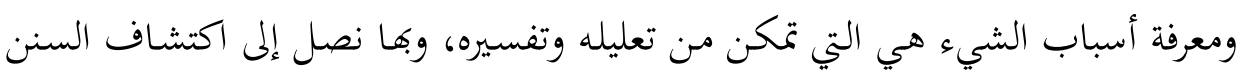
الكونية أو الاجتماعية.

وإذا كانت هذه أبرز الأسس أو الأصول التي يقوم عليها علم التاريخ، وهي أصول

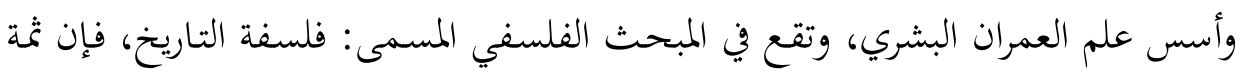

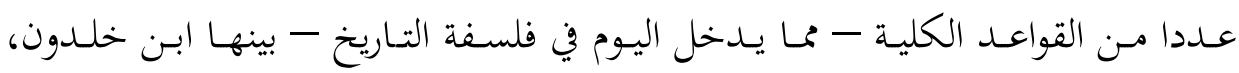

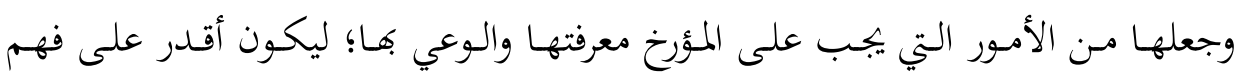
أحداث التاريخ وتعليلها، وأبرز هذه القواعد الكلية: * العصبية, وهي السبب الرئيس المؤسس لقيام الدولة.

$$
\begin{aligned}
& \text { المرجع السابق، ج1، ص347-348. } \\
& \text { المرجع السابق، ج1، ص282، صلم2 }
\end{aligned}
$$


* الدولة محكومة بتطور حتمي: النشأة والشباب، ثتم الاستقرار والحضـارة، تم الهرم والاضمحلال المؤدي إلى انتهاء الدولة.

* يبدأ تطور المجتمع بالبداوة، ويتدرج إلى الحضارة مع وجود الدولة.

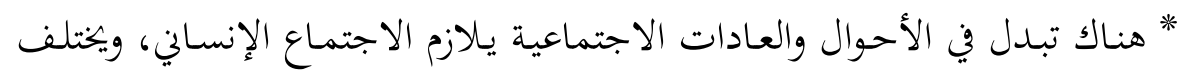
باختلاف العصور، وهو المسمى في علم الاجتماع اليوم بالتغير الاجتماعي. * تكثر العلوم والصناعات حيث يكثر العمران وتعظم الحضارة.

ويحسـن التنبيه إلى أن إيرادنا لهذه الأسس والقواعـد لا يعني البتـة أفها قضـايا مسلم

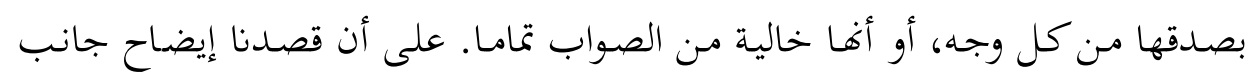

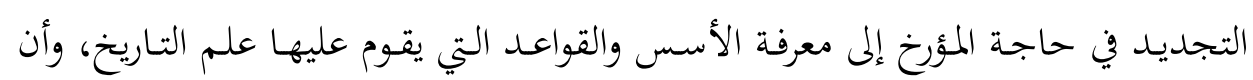
ابن خلدون كان سباقا إلى الكلام في هذا المجال الذي عرف ولئ باسم: فلسفة التاريخ.

\section{ثالثا: الإصلاح والتجديد في علم الكلام:}

أعطى ابن خلدون علم الكـلام قـدرا مـن اهتمامهـ ضـمن كلامهه عن العلوم النقلية

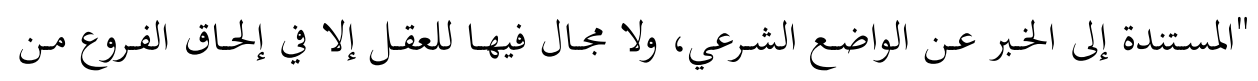

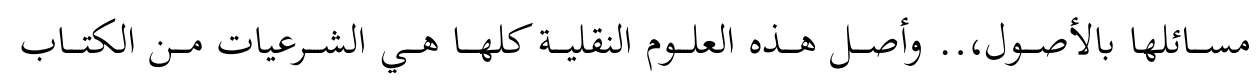
والسنة."(71)

والواقع أن ابن خلدون، كما يبدو فيما كتبه عن علم الكلام، وما يظهر بصورة غير

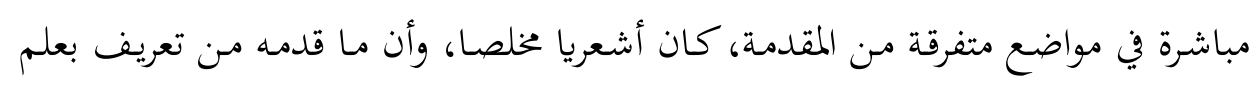
الكاملام عبر في ثناياه عن أبرز معتقداته التي هي معتقدات الأشـاعرة، فضلا عن من تأكيده

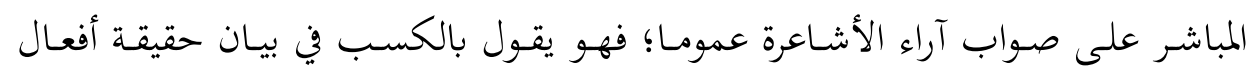

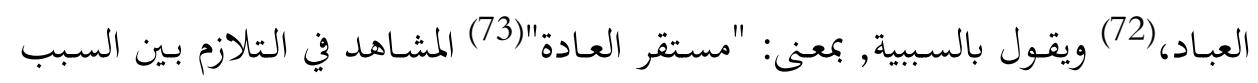

$$
\text { المرجع السابق، ج3، ص3، ص1026. }
$$




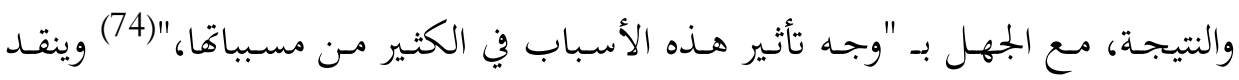

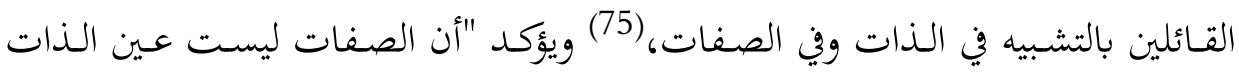

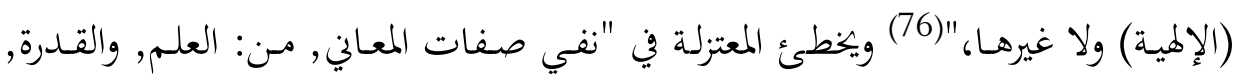

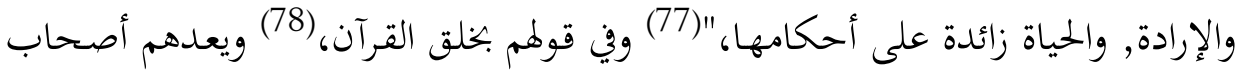
بدعة في ذلك.

والحق أن عرضه لتطور علم الكلام يشير إلى إتقان وفهم دقيق لهذا العلم وقضاياه،

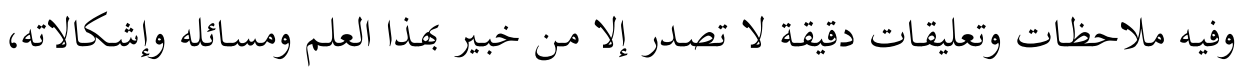

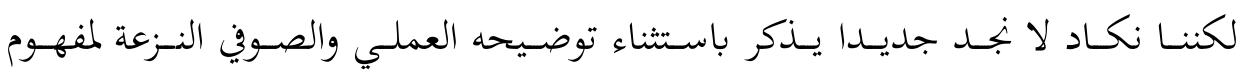

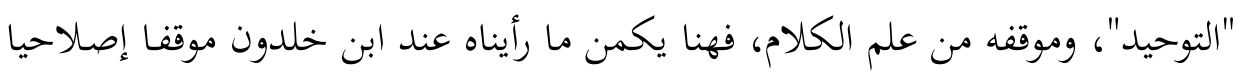
بحديديا، يمكن توضيحه في الآتي:

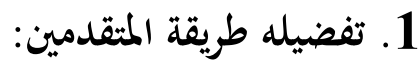

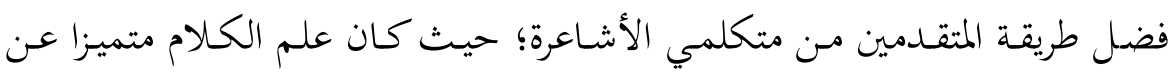

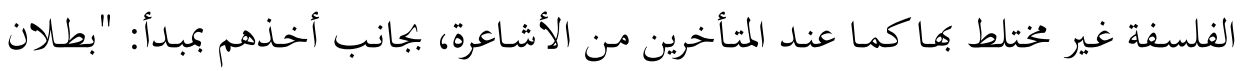

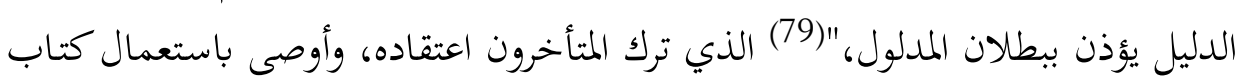

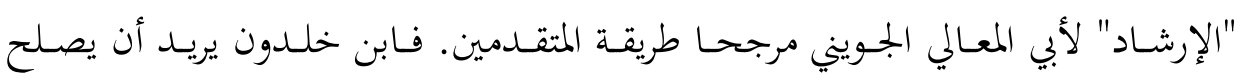
الوضع القائم المختلط في علم الكلام بإعادة اتباع طريقة المتقدمين.

2. 2 التحليل النقدي لأسباب الحلاف بين الفرق:

$$
\begin{aligned}
& \text { المرجع السابق، ج3، ص1069، ص1070. } \\
& \text { المرجع السابق، ج3، صـابق، ص1070، ص1077. } \\
& \text { المرجع السابق، ج3، ص3، ص1077، ص1078، صل1078. } \\
& \text { المرجع السابق، ج3، ص31078، ص1078. } \\
& \text { المرجع السابق، ج3، ص1078، ص1078. }
\end{aligned}
$$

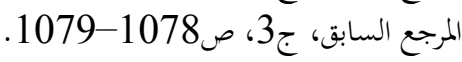

$$
\begin{aligned}
& \text { المرجع السابق، ج3، ص1081، ص1018. }
\end{aligned}
$$


قدم تحليلا نقـديا دقيقـا بـين فيـه أسباب الخـلاف في تفاصيل العقيدة لـدى الفـرق

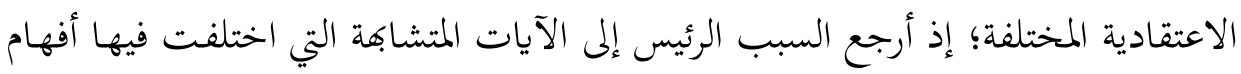

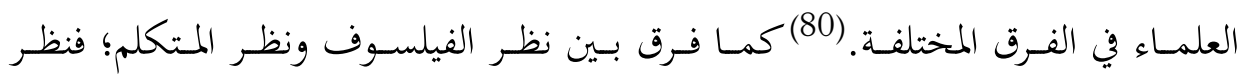

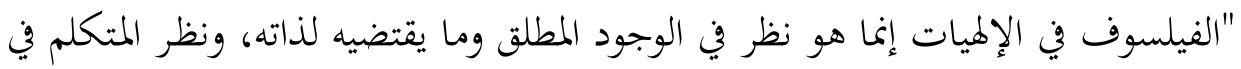

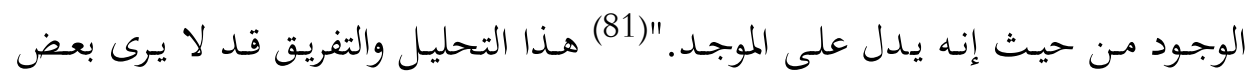
الباحثين فيه جديدا يضاف إلى المعرفة في مجاله، لكن الجديد في بيانه أنه يريد إصلاح

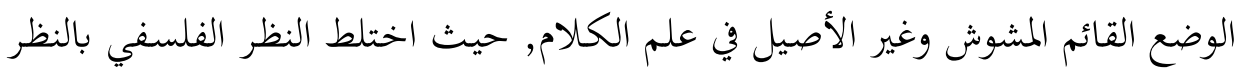
الكامي، فكان كلامه في ضوء مقصده إصلاحا وبتديدا.

\section{3. بيان أهمية العقل وحدود إدراكه:}

أكد أهمية العقل في مجال إدراكه، وبين حدوده؛ فالإنسان يدرك من الوجود بحسب

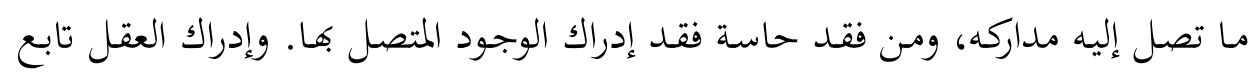

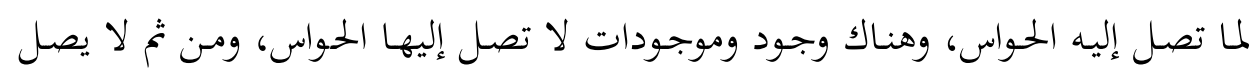

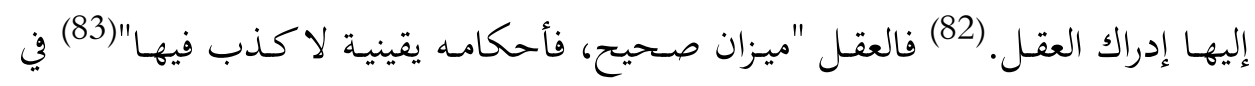

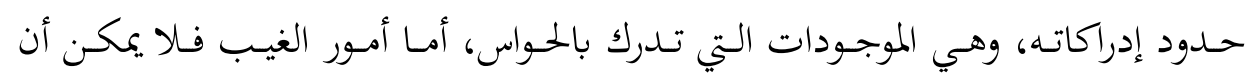

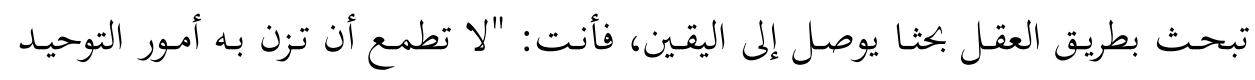

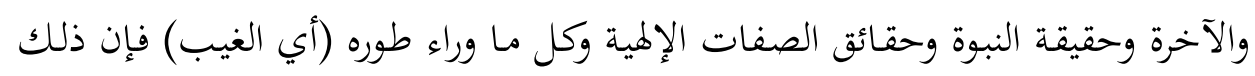

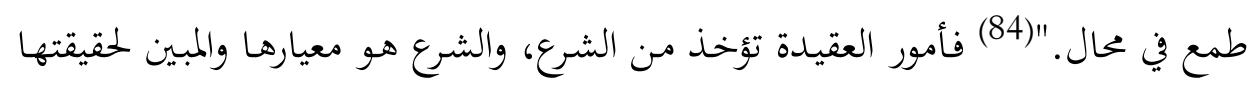

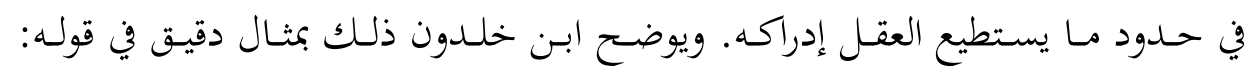

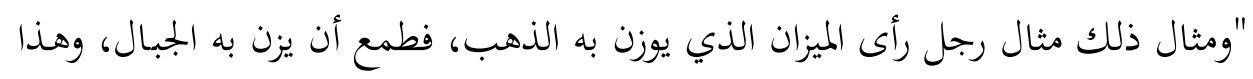

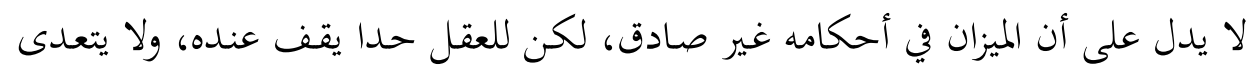

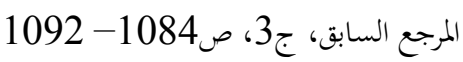

$$
\begin{aligned}
& \text { المرجع السابق، ج3، ص31082، ص1071. } \\
& \text { المرجع السابق، ج3، ص1071، ص1072. }
\end{aligned}
$$

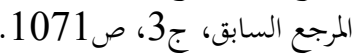

$$
\begin{aligned}
& \text { المرجع السابق، ج3، ص1071، ص1071. }
\end{aligned}
$$


ودراسات

طوره حتى يكون له أن يحيط بالله وبصفاته، فإنه ذرة من ذرات الوجود الحاصل منه."(85)

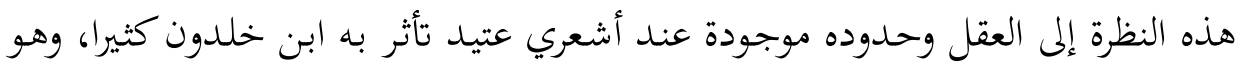

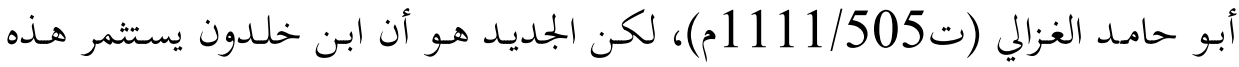

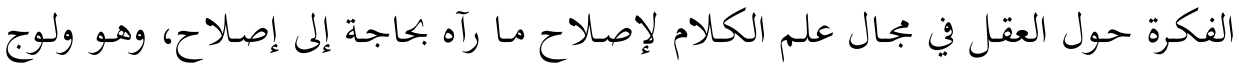
العقل إلى ميدان لا يستطيع الخوض فيه بسبب طبيعته، وهو ميدان الغيب بعامة, وميدان التوحيد بخاصة.

\section{4. بيان مفهوم جديد للتوحيد:}

طرح ابن خلدون مفهوما للتوحيد نعده جديدا في سياق علم الكالام وإن كان هذا

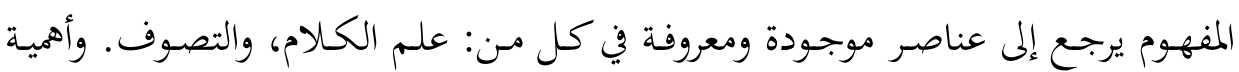

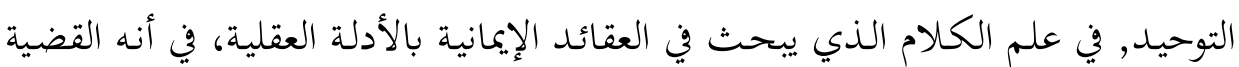

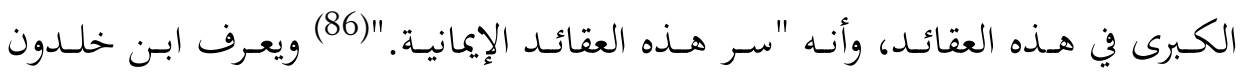

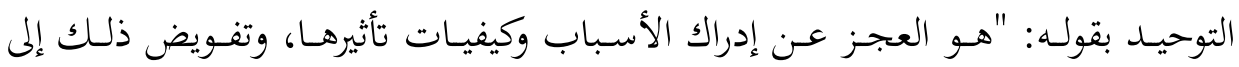

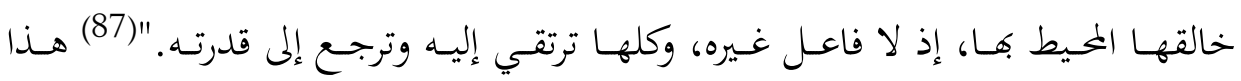

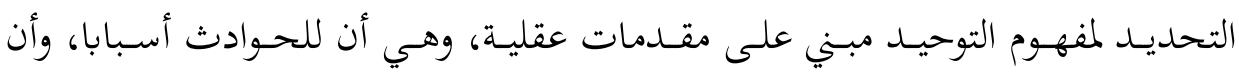

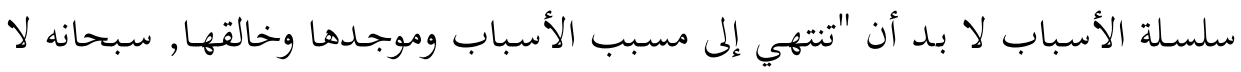

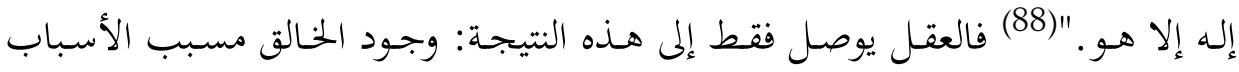

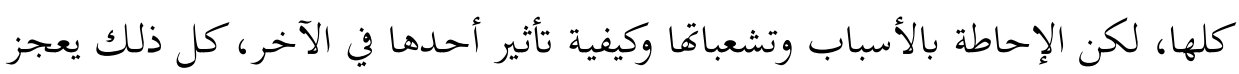

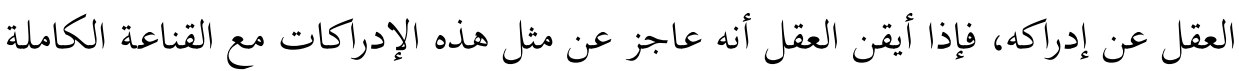

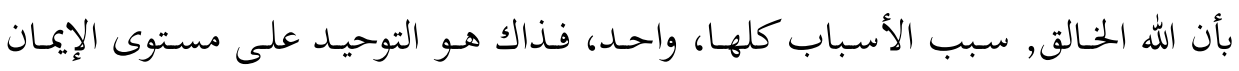

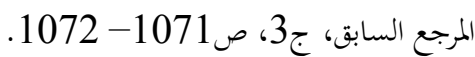

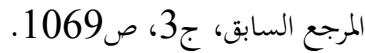

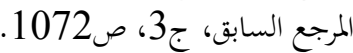

$$
\begin{aligned}
& \text { المرجع السابق، ج3، ص31069، صلمابع. }
\end{aligned}
$$




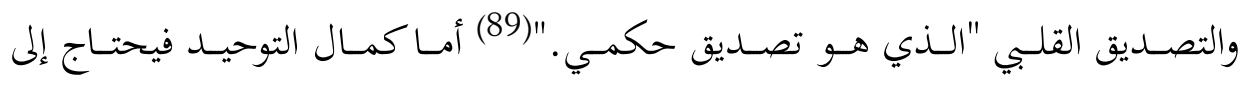

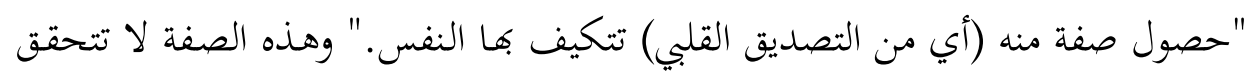

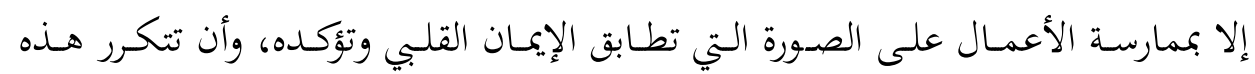

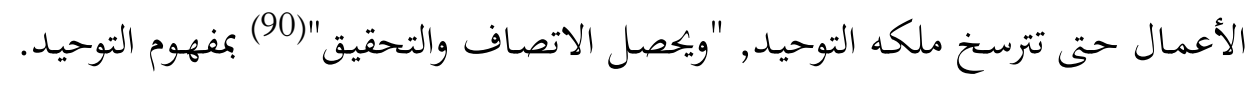

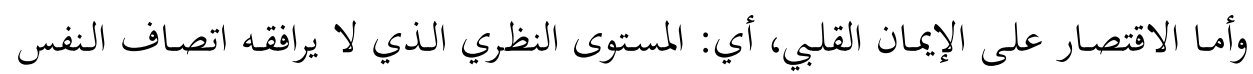

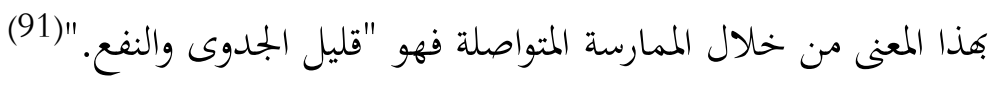
ولعل هذه العبارة الأخيرة هي مفتاح الفهم لحقيقة الإصلاح والتجديد الذي يريده

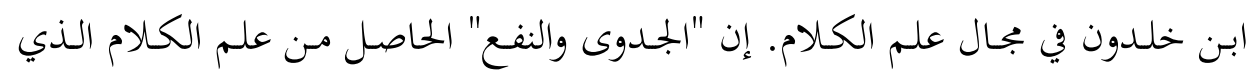

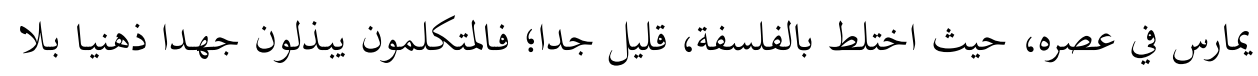

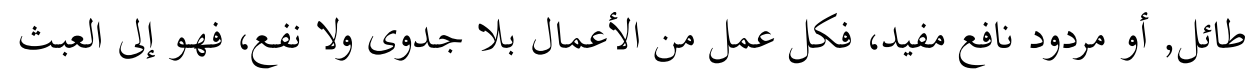

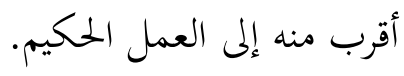

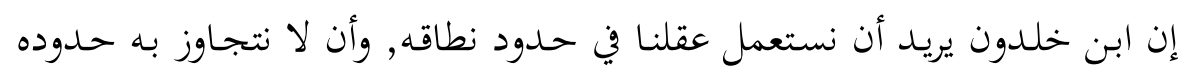

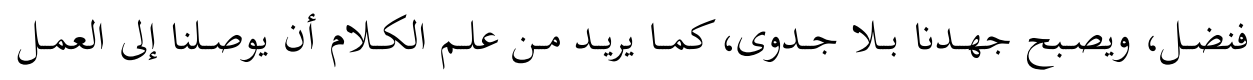

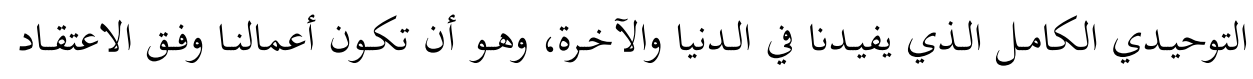

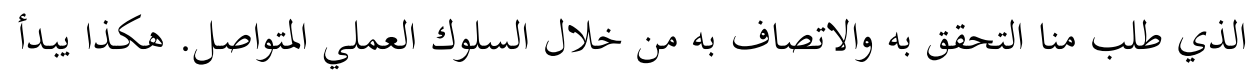

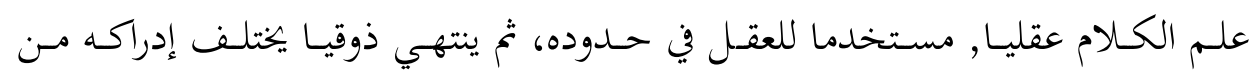

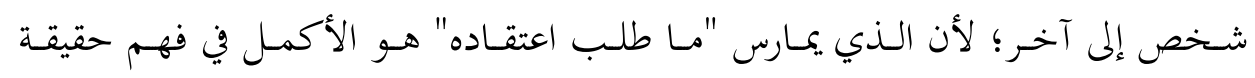

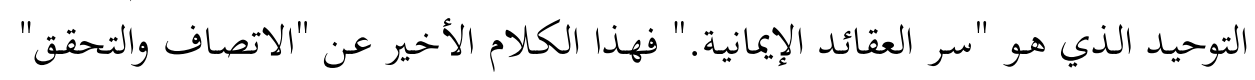
لا يختلف في جوهره عن كلام الصوفية في موضوع التوحيد والتحقق به.

هذا الموقف من علم الكلام موقف جديد في عصر ابن خلدون وهو يهدف منه إلى

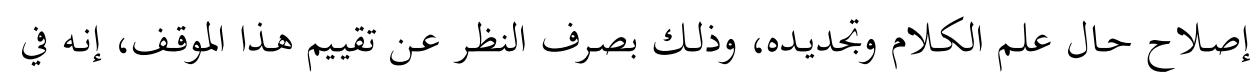

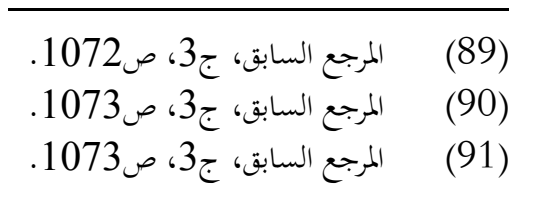


واقع الحال موقف فكري ينسجم مع الموقف الإصلاحي التجديدي للفكر، الذي هدفه

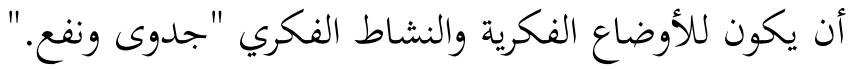

\section{5. - 5 - 5 الجانب العملي من علم الكلام:}

يـرى ابـن خلـدون أن علم الكـلام ينبغي أن لا يقـف عنــ مسـتوى المعرفـة النظريـة

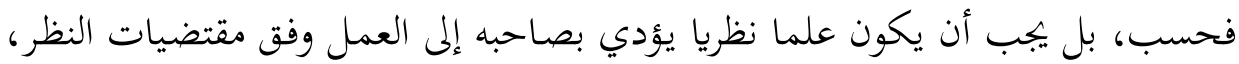

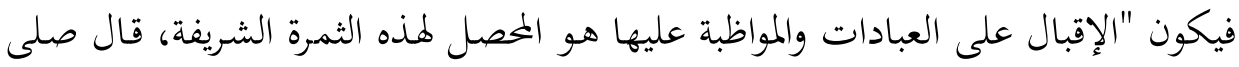
الله عليه وسلم في رأس العبادات: جعلت قرة عيني في الصلاة. فإن الصـلاة صـارت له له

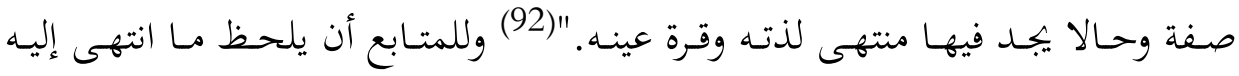

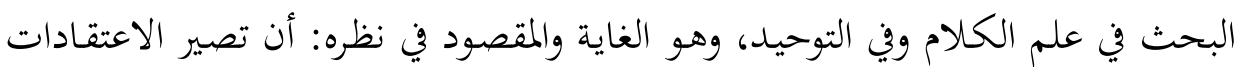
والعبادات "صفة وحالا ," وهـذاكـلام صوفي مستنير ملتزم بضوابط الشـريعة. إنه كحلام جديد في سياق علم الكلام, وبهذا الوصف المتقدم يصبح علم الكلام له "جدوى ونفع."

\section{6. قصر علم الكلام على أهل الاختصاص:}

يرى ابن خلـدون أن يقصر دراسـة علم الكلام -وفقـا للطريقـة التي فضلها- وهي

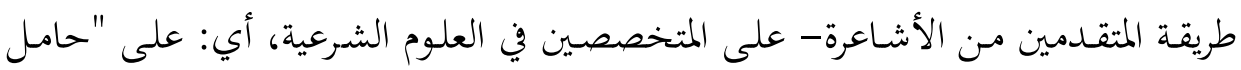

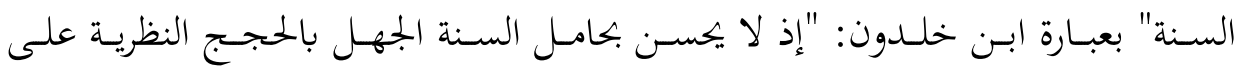

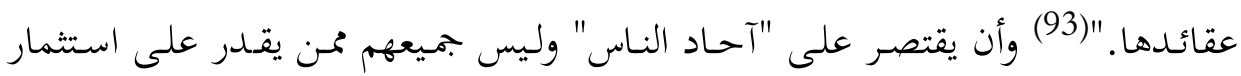
العلم النظري ليصل به إلى هايته بأن يصيره صفة له وحالا. وعليه، فإن "هـا العلم الذي هو علم الكالام غير ضروري لهذا العهد على طالب

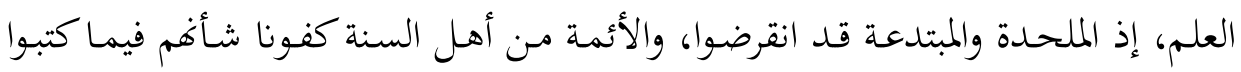

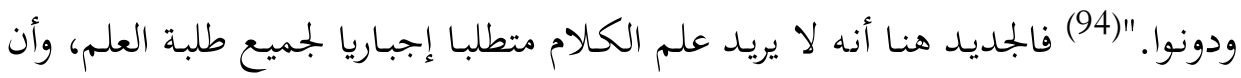

\begin{tabular}{|c|}
\hline المرجع السابق، ج3، ص1073. \\
\hline المرجع السابق، ج3، ص1083. \\
\hline المرجع السابق، ج3، ص1083. \\
\hline
\end{tabular}


تقتصر دراسته على المتخصص في العلم الشرعي؛ ذلك أنه كان بعض المتكلمين المتأخرين

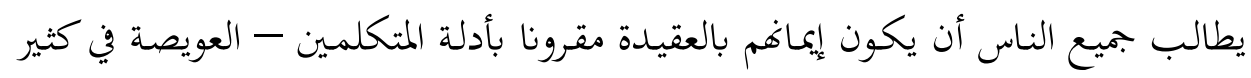
من الأحيان- وإلا كان إيمافم ناقصا.

\section{رابعا: الإصلاح والتجديد في الفلسفة:}

بدأ ابن خلدون حياته الدراسية المتخصصة بالاشتغال بعلوم الفلسفة وعلم الكلام، بعـد دراسته للعلوم الشرعية. ويتضح للمتخصص في الفلسفة -مـن خلال مـا أورده في المقدمـة عـن الفلسفة ومباحثهـا- تمكنه مـن مـنهج الفلسفة وروحها، ومعرفتـه بأسسـها ومنطلقاتها، ومقاصدها وغاياتا، إضافة إلى المعرفة بآراء الفلاسفة ومذاهبهم. يضاف إلى ذلك كله أنه وضع مبحثا فلسفيا لأول مرة, هو مبحث فلسفة التاريخ. والنتيجة من كل ما تقدم أنه في الفلسفة عريق، وجدير أن يعد من أعلامها وخليق.

بالرغم من هذه النتيجة، فإن الناظر في موقف ابن خلدون السلبي من الفلسفة, وما

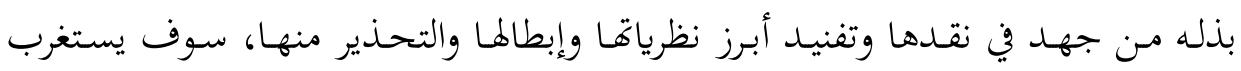

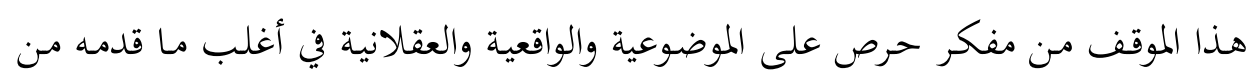
آراء واجتهادات في المقدمة، وإن الأمر يتطلب -وفقا لماكان يطلبه من المؤرخ- تحقيقا وتعليلا وتفسيرا، وتطبيقا لمعيار مطابقة الواقع، وعدم الاكتفاء بالوقوف عند الظاهر.

\section{1. فهم ابن خلدون للفلسفة، ونقده لما:}

بدأ ابن خلدون كلامهه عن الفلسفة بالتأكيد في أول جملة منه على أمرين: أولمما: موضوع الفلسفة, وذلك في الفصول التي تتحدث عنها, وصناعة النجوم, والبحث عن بن

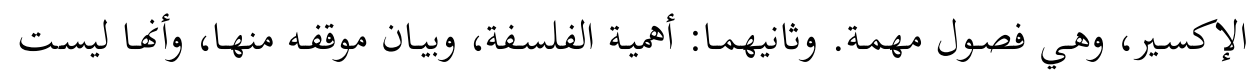


أساسية في العمران، فهي عارضة فيه بالرغم مـن انتشارها في المدن، مـع أن "ضررها في الدين كثير. "(95)

موضوع الفلسفة عند ابن خلدون هو الوجود كله: الحسي (عالم الطبيعية) وما وراء

$$
\text { الحسي (96) (ما بعد الطبيعة). }
$$

ومنهج البحث في الفلسفة: الأدلة العقلية المختلفة, ومنها علم المنطق. وقد وضعه

الفلاسفة "قانونا يهتدي به العقل في نظره إلى التمييز بين الحق والباطل."(97)

غاية الفلسفة: الوصول إلى العلم بحقيقة الوجود، بجانبيه: الحسي, وما وراء الحسي,

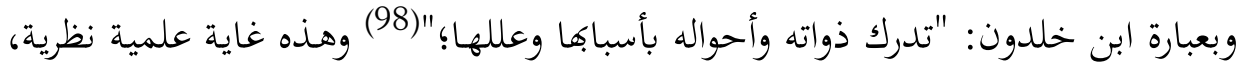

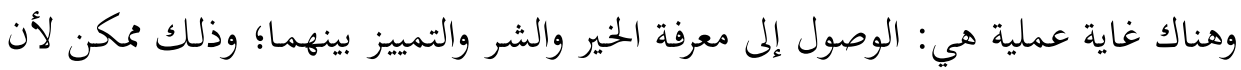
الإنسان-في نظر بعض الفلاسفة- قادر على ذلك بعقلة ونظره وفطرته التي تميل إلى

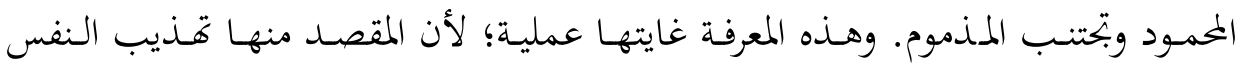

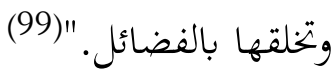

وظيفة الفلسفة: ما تقوم به الفلسفة في الحياة مرتبط بغايتها ذات الجانبين: النظري, والعملي. فالوظيفة المرتبطة بالغاية النظرية هي: زيادة علمنا بحقائق الأشياء والوصول إلى بلى بلى بلهي

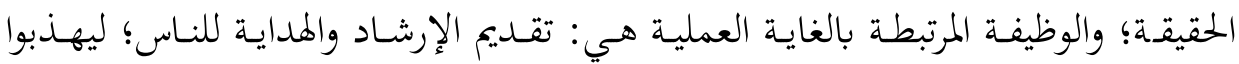

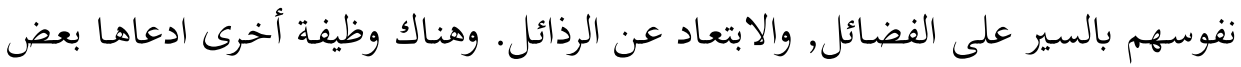

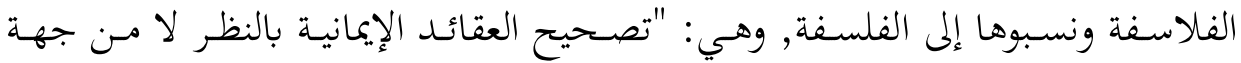

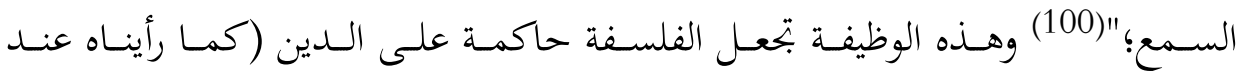

$$
\begin{aligned}
& \text { (95) المرجع السابق، ج3، ص1209. }
\end{aligned}
$$

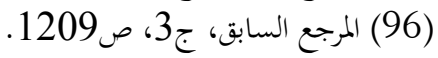

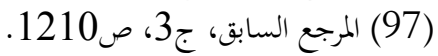

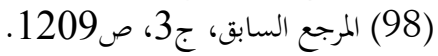

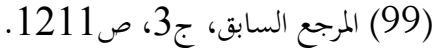

$$
\begin{aligned}
& \text { (100) المرجع السابق، ج3، ص1209، ص1211. }
\end{aligned}
$$


الفيلسوف المعروف: الفارابي، المتوف 339 هـ)،(101) ومنافسة للدين في وظيفته الرئيسة,

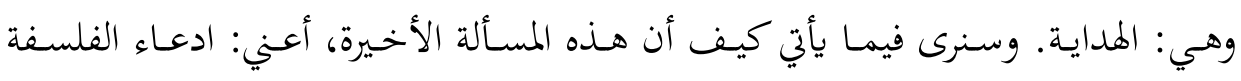

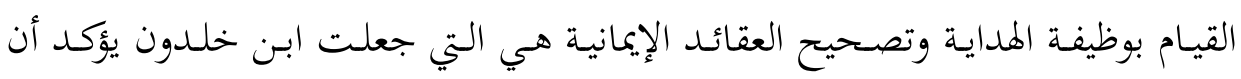

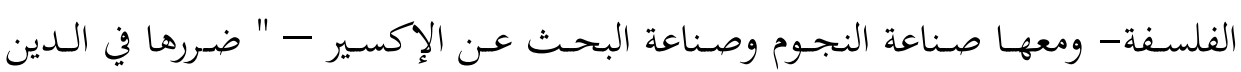
كثير. "(102)

ثمرة الفلسفة: هي الوصول إلى السعادة الحقة في نظرهم، التي هي سعادة معنوية أو

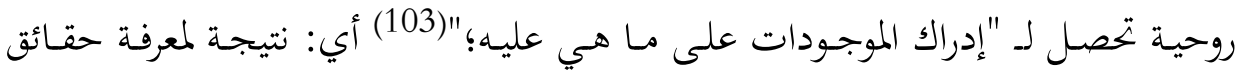

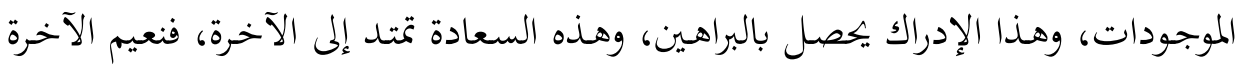

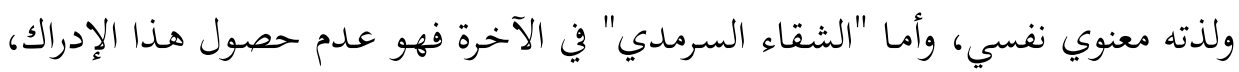

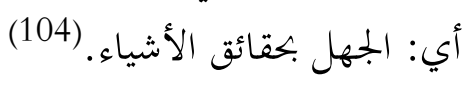

استشعر ابن خلدون خطر الفلسفة على الدين، بل وخطرها على العمران البشري

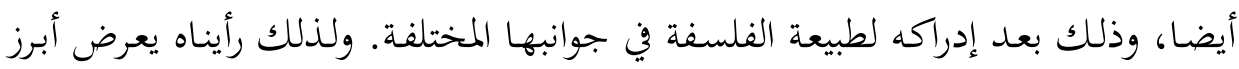
آرائهم, ويحاول إبطالها وإظهار تمافتها؛ دفاعا عن الدين، وعن العمران البشري المنشود. لقد كانت الفلسفة في عصر ابن خلدون مختلطة بعلم الكلام، وكانت الأذهان تتوجه

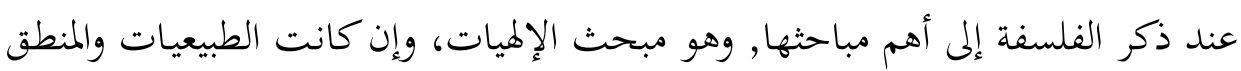

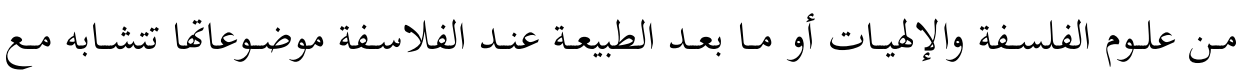
موضوعات العقيدة وتتقاطع معها، ومن هنا جاء الجانب الأكبر من ضررها على الدين, أعني: من مبحث الإلهيات.

لقد كان الفلاسفة (بعضهم على الأقل) يرون أن لكل فلك في الأجرام السماوية

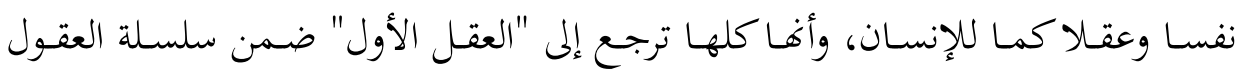
(101) السيد، عزمي طه. الدين والإيديولوجيا في مشروع الفارابي السياسي، المفرق( الأردن): دار المسار للنشر

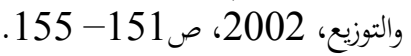

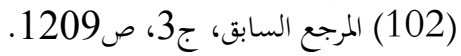

$$
\begin{aligned}
& \text { (103) المرجع السابق، ج3، صنابق، ص1214، ص1215. } \\
& \text { (104) المرجع السابق، ج3، ص3103، ص1215. }
\end{aligned}
$$


ودراسات

التسعة التي زعموها للأفلاك. وهذا في نظر ابن خلدون "قصور عما وراء ذلك من رتب

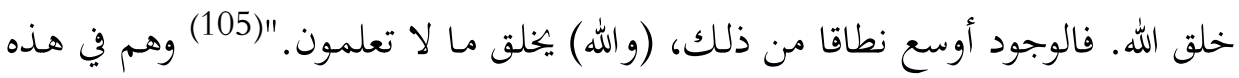

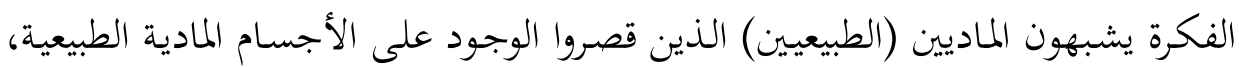
"المعتقدين أنه ليس وراء الجسم في حكمة الله شيء."(106)

وكانوا يرون أن المنهج الذي يوصل إلى إدراك حقيقة الوجود هو صناعة المنطق التي

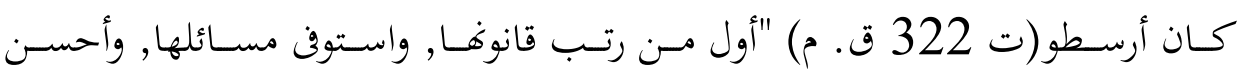
بسطها."(107) وهذا المنهج الذي يقوم -في نظرهم- على تقديم البراهين، هو في نظر ابن

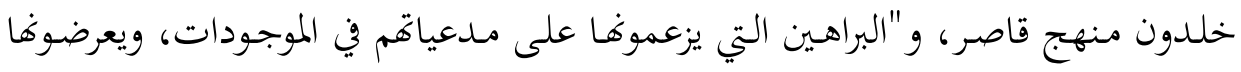

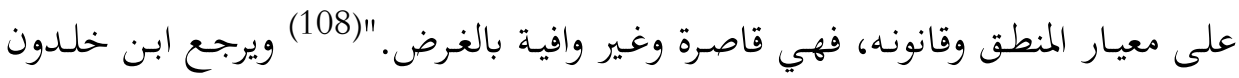

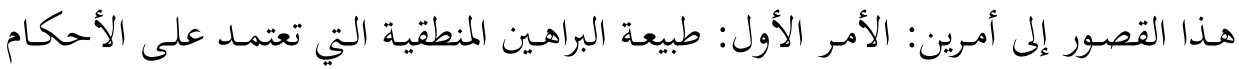

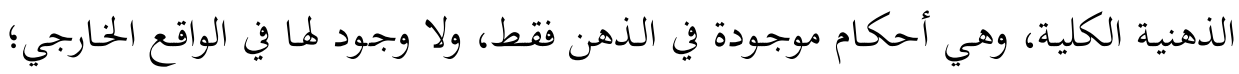

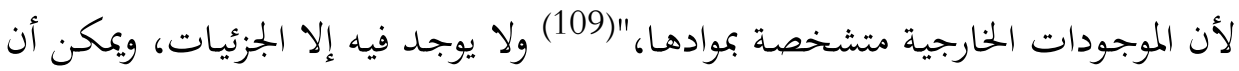

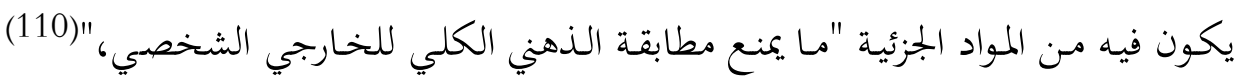

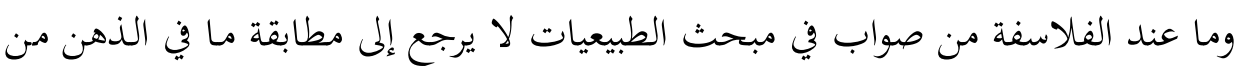

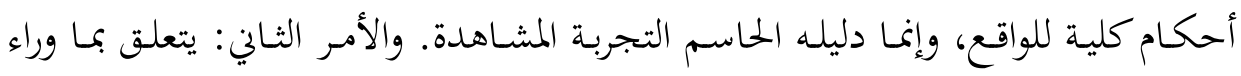

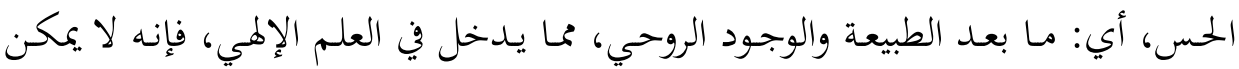

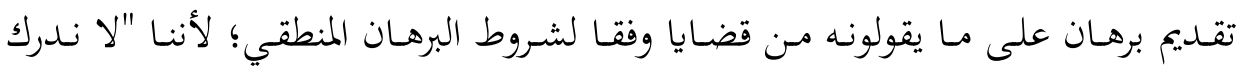

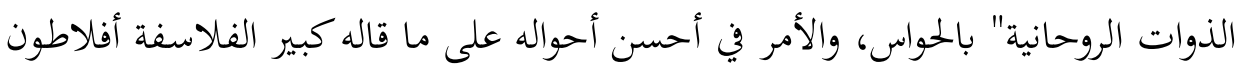

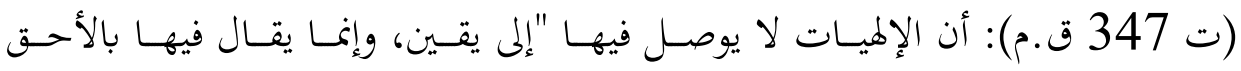

$$
\begin{aligned}
& \text { (105) المرجع السابق، ج3، ص1212. } \\
& \text { (106) المرجع السابق، ج3، صنابق، ص1212. } \\
& \text { (107) المرجع السابق، ج3، صر3، ص1212، ص1212. }
\end{aligned}
$$

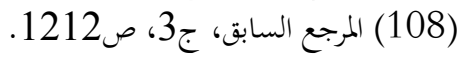

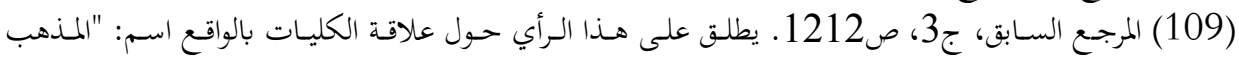

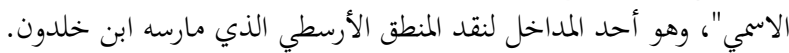

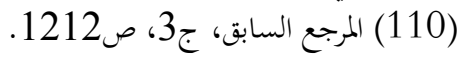


والأولى, يعني: الظن،"(111) إشـارة إلى استخدام الاستدلال التمثيلي الذي نتائجه ظنية (وهو الاستدلال المعروف عند المتكلمين باسم: قياس الغائب على الشاهد.) وبما أننا في

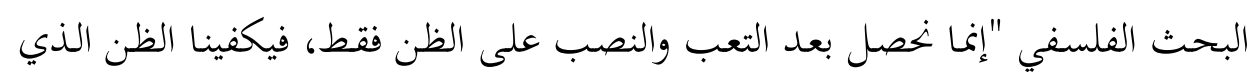

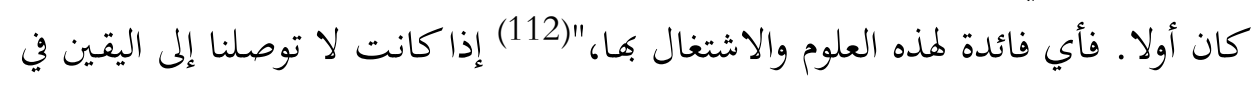

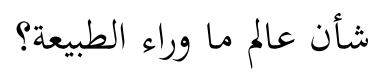

ويرى الفلاسفة (أو بعضهم على الأقل) أن السعادة هي في إدراك الموجودات على هلى

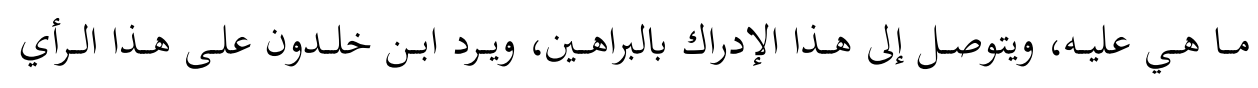

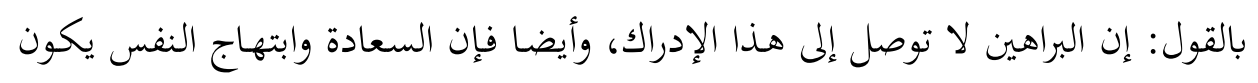

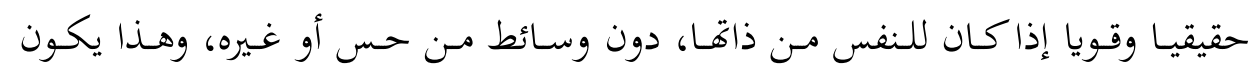

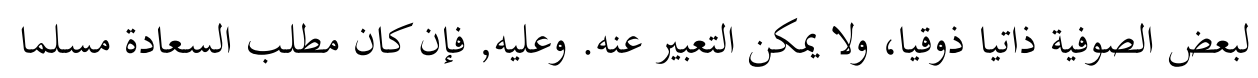

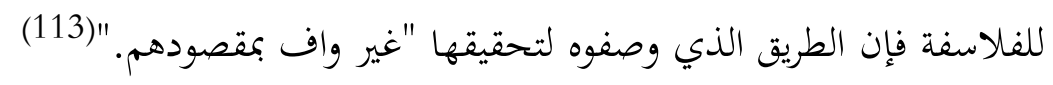
ويرون أن الإنسـان قادر عن طريق الفلسفة بـ "عقله ونظره" أن يميز بين الفضيلة والرذيلة؛ إذ لديه ميل فطري للفضيلة واجتباب الرذيلة. ولماكان إدراك الإنسان للوجود الإنسان

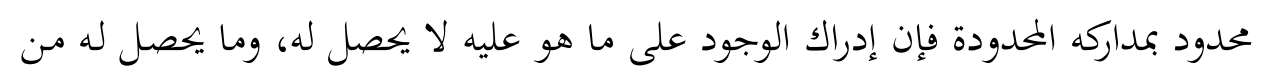

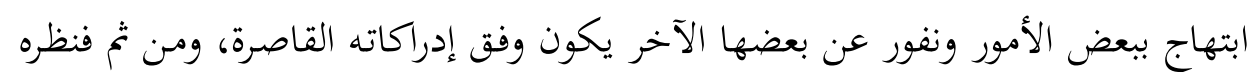

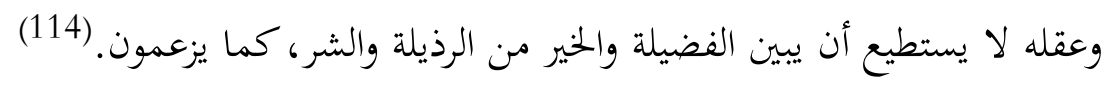
والخلاصة أن علم الفلسفة لا يحقق ما نصبه له الفلاسفة من أهداف، وهذا السبب كاف لإبطال الاشتغال بها، وهناك سبب آخر وهو "ما فيه (علم الفلسفة) من مخالفة

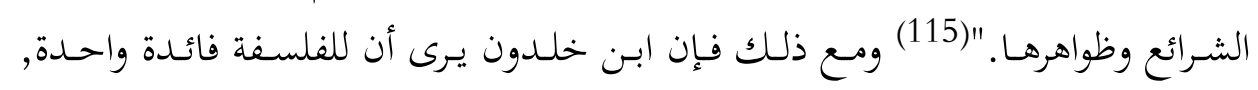

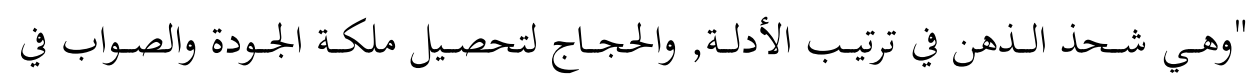

$$
\text { (111) (111) المرجع السابق، ج3، ص1113) المرجع السابق، ج3، ص1213. }
$$

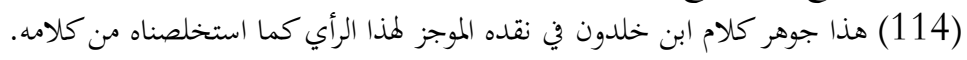

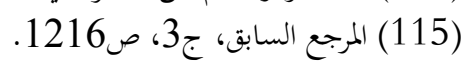




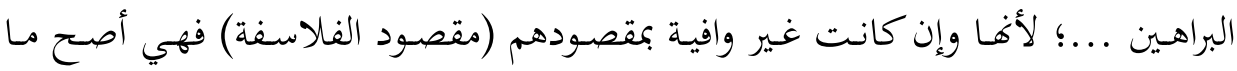

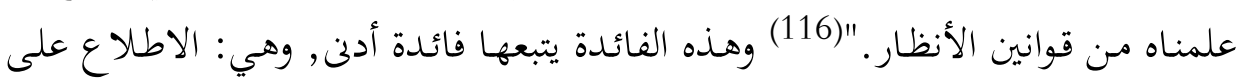
مذاهب الفلاسفة وآرائهم. أما مـا خرج به من توصيات بعد هـذاه النقد فهو أن لا يبدأ

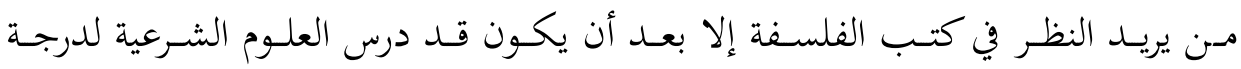

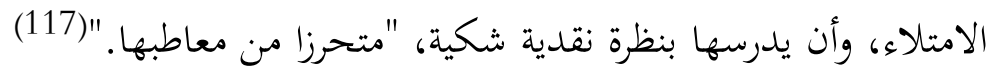

\section{2. جوانب التجديد في الفلسفة عند ابن خلدون:}

إذا كان المقصود بالتجديد هنـا: إضـافة مبحث جديـد, أو تقديم نظريـة جديدة في

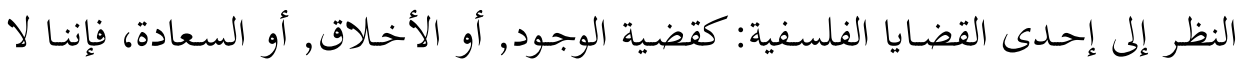

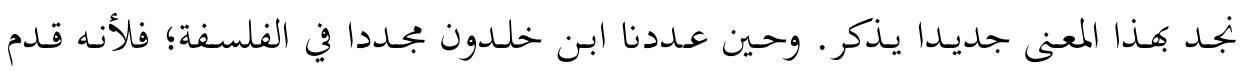

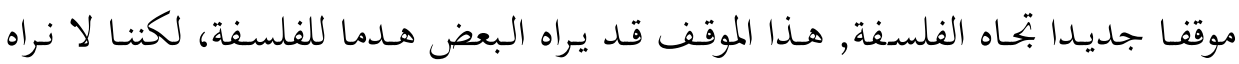
كذلك بالكلية، ونرى فيه جانبا إيجابيا سنوضحه لاحقا -إن شاء الله - لكننا نورد فيما

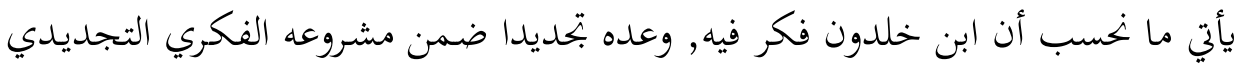
الواسع:

1 ـ عمل على هـدم الفلسفة, أوالتقليص مـن دورها ووظيفتها الفكرية لصالح علم

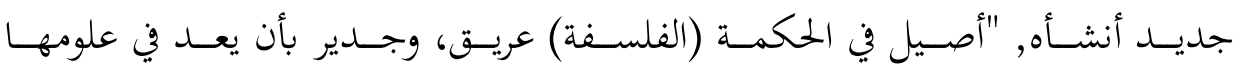
وخليق."(118) وهذا العلم الفلسفي الجلديد يريد ابن خلدون لطلبة العلم العقلي أن يقبلوا

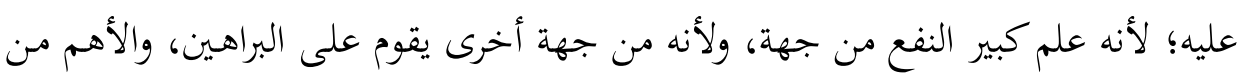

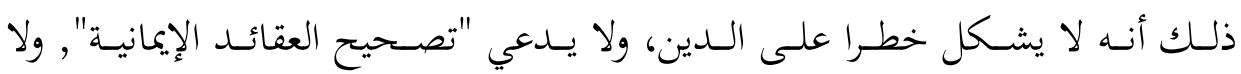

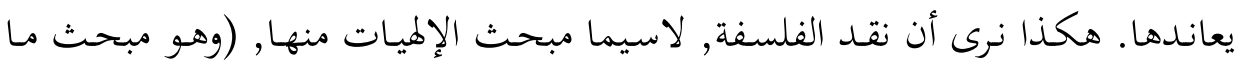

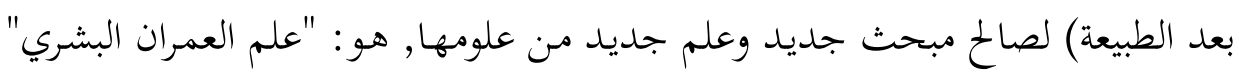
هو جانب من جوانب التجديد الفكري في نظر ابن خلدون.

$$
\begin{aligned}
& \text { (116) المرجع السابق، ج3، ص1217، }
\end{aligned}
$$

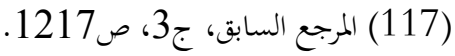

$$
\begin{aligned}
& \text { (118) المرجع السابق، ج1 الماب، ص3، ص282. }
\end{aligned}
$$


2. بيان ضرر علم الفلسفة على العمران حين ينافس الدين في الهداية والإرشاد،

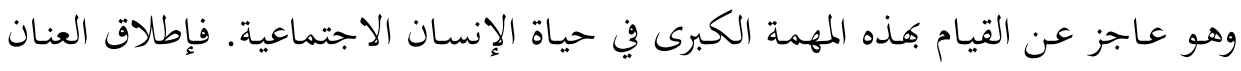

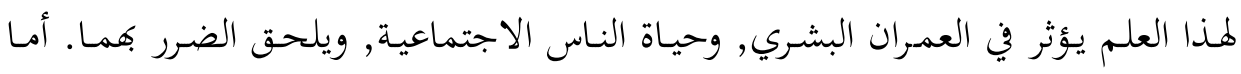
البديل الجديد فإنه لا توجد فيه هذه السلبية، وإنما هو علم نافع لمعرفة حقيقة العمران. 3. نادى بفصل الفلسفة عن علم الكالام؛ بسبب ما حدث عند متأخري المتكلمين

من مزج بينهما, بحيث كادت معالم كل علم أن تتلاشى في معالم العلم الآخر.

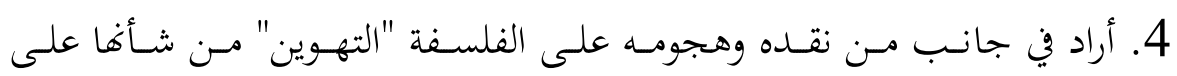
المستوى النظري وعلى المستوى العملي. فعلى المستوى النظري فإِن الفلسـفة لا توصـلنا إلا إلى ظــون, لاسـيما في مجـال:

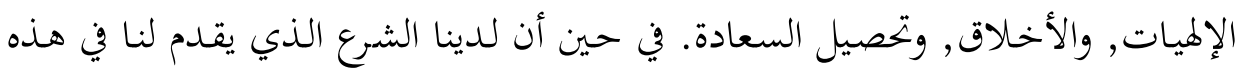
المجالات علما ومعرفة يقينية مؤكدة. وأمـا على المستوى العملي فإن هداية الشرع هداية إلهية، وهداية الفلسفة محدودة؛

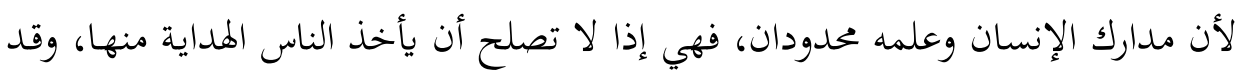
أغناهم الله بهدايته التي تعكس علمه المطلق.

5. يتبع هذا الجانب العملي في التهوين من شأن الفلسفة زعم الفلسفة أها توصل الإنسان إلى السعادة الحقة التي هي في جوهرها عندهم لذة النفس وبهجتها بإدراك حقائق

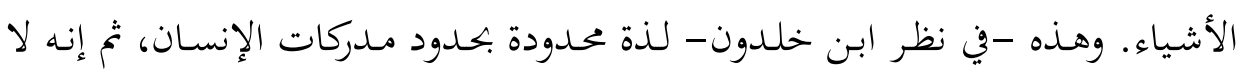

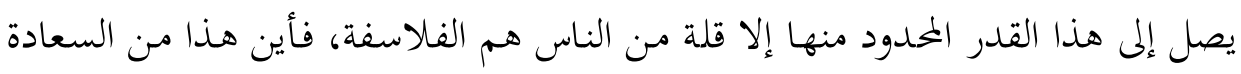

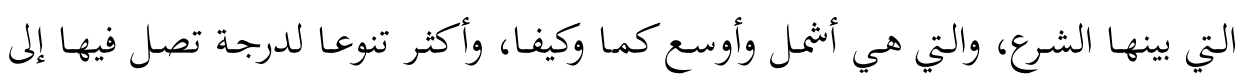

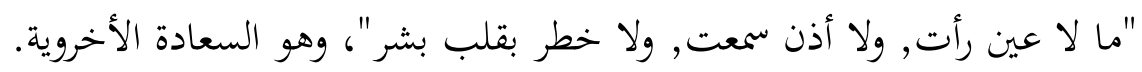


قدم ابن خلدون عرضا موجزا ومفيدا عن نشأة التصوف, وتطوره, وبيان حقيقته, ورأيه فيه. إضافة إلى نقد بعض النظريات التي نقلت عن عدد من الصوفية, مثل: الحلول والاتحاد. ويلاحظ على كلام ابن خلدون عن التصوف أنه صاحب خبرة عمدية علية فيه، وأنه ليس باحثا فحسب، كما يلاحظ -أيضا- تعاطفه القوي مع التصوف الذي نعلم تاريخيا

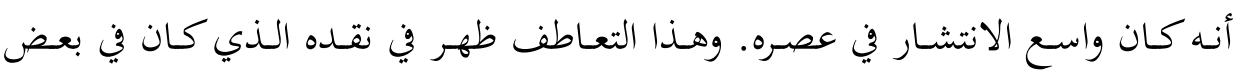

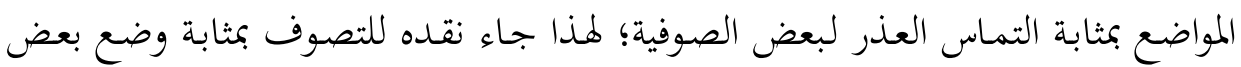

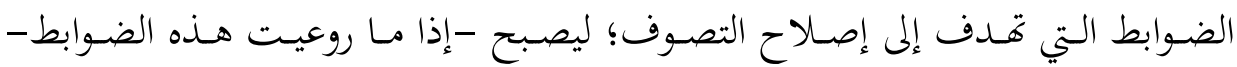
مقبولا.

ونورد فيما يأتي أبرز هـذه الضـوابط (الإصـلاحية) التي قدمها ابن خلدون في بجال التصوف:

1. السلوك الصـوفي ينبغي أن لا يخرج عن "الطاعـة والإخلاص"(119) لله، ويكون مبنيا على الإيمان.

2. على المريد السالك أن يكثر من "عحاسبه نفسه في سائر أعماله؛"(120) حتى لا

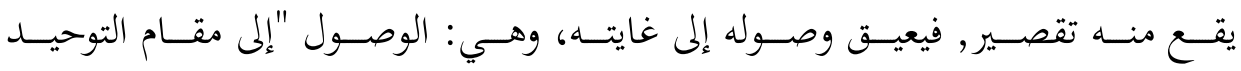
والعرفان." (121)

3. المجاهـدة قـد توصل إلى الكشف، فإذا كوشف السالك فعليه أن ينضبط بعدد

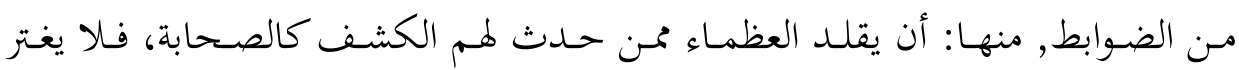
بالكشف, ولا يخبر "عن حقيقته شيئا لم يؤمر بالتكلم فيه. "(122) ويعد ما وقع لهن له محنة.

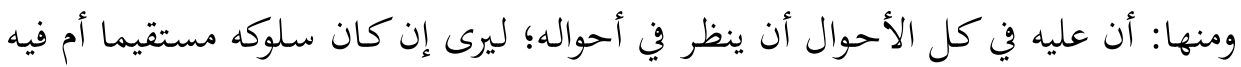

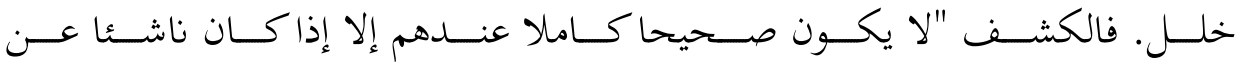

$$
\text { (120) (121) المرجع السابق، ج3، ص121) المرجع السابق، ج3، ص1098. }
$$


الاستقامة؛"(123) ذلك أنه قـد يحصل كشـف بسـبب رياضـات وسـلوك غير مستقيم. ومنها: عدم وصف تجربة الكشف بطريقة أهل العلم الظاهر؛ لأن تفهيم ذلك للآخرين غير ممكن، ويزيد الأمور غموضا، ولا فائدة منه للآخرين. 4. يرى ابن خلدون أن لا فائدة في صوغ نظريات حول حقيقة الألوهية والتوحيد

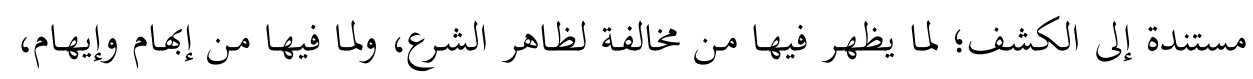
ولاستحالة هذا الأمر بحسب طبائع الأمور. (124)

5. لا يقر ابن خلدون الصوفية في قولهم بالقطب "لتعلم المعرفة بالله؛ لأنه لا يقر

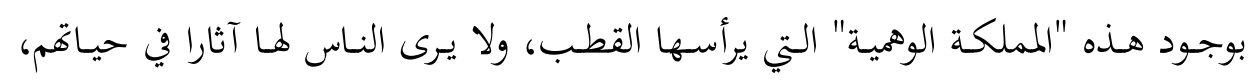

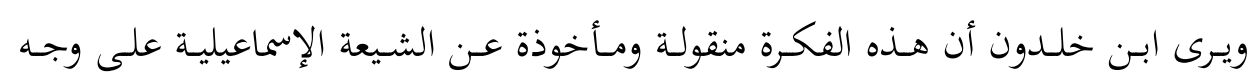

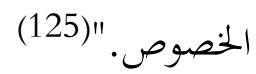

6. قـدم ابسن خلـدون تحلسيلا وتقييمـا للسـلوك الصـوفي في عناصـره المختلفـة، وبـين

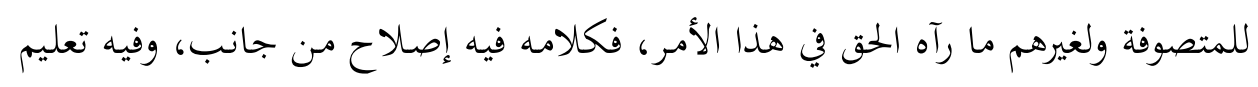

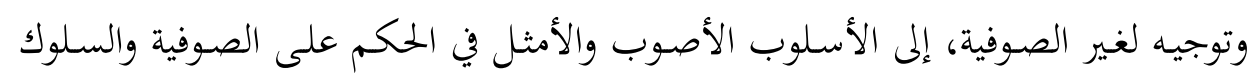
الصوفي وتقييمه.

وقد قسم ابن خلدون السلوك الصوفي إلى أربعة عناصر، وقيم كل عنصر على النحو الآتي:

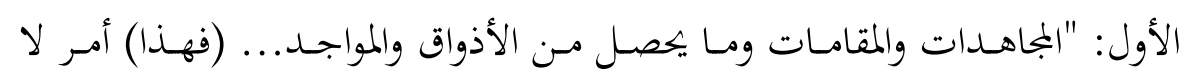
مدفع فيه لأحد، وأذواقهم فيه صحيحة, والتحقق بها عين السعادة."(126)

$$
\begin{aligned}
& \text { 123) المرجع السابق، ج3، ص1104) المرجع، ص1107. }
\end{aligned}
$$

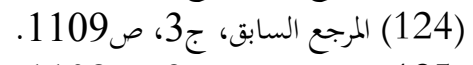

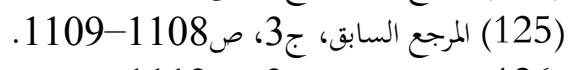

$$
\begin{aligned}
& \text { (126) المرجع السابق، ج3، صن، ص1112. }
\end{aligned}
$$


الثاني: "كرامـات القوم, وإخبارهم بالمغيبات, وتصرفهم في الكائنات، فأمر صحيح

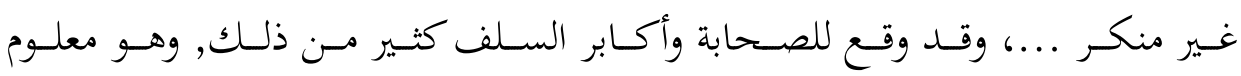
مشهور." "(127)

الثالث: "الكشف, وإعطاء حقـائق العلويات, وترتيـب صـدور الكائنسات، (فهذا)

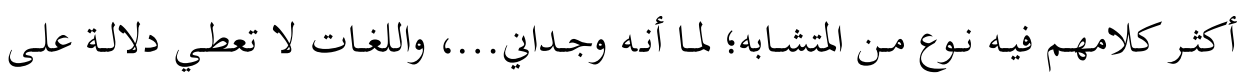

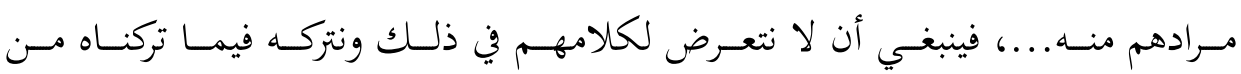
المتشابه." (128) (28)

الرابع: "الألفاظ الموهمة التي يعبر عنها بالشطحات ويؤاخذهم بها أهل الشرع، فاعلم

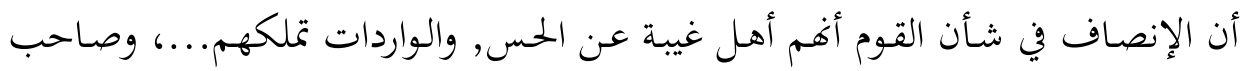

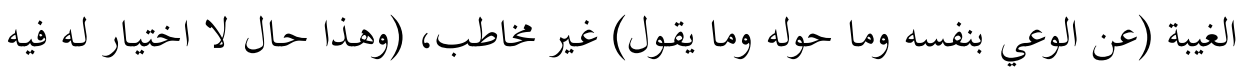

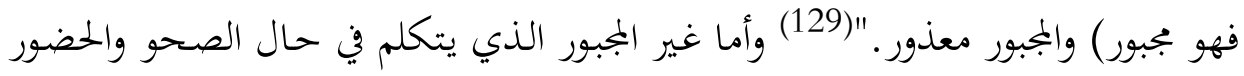

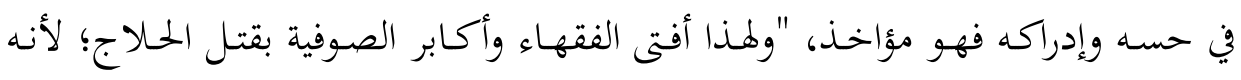
تكلم في حضور وهو مالك لحاله."(130)

نلمسس في هـذا التقيـيم إصـلاحما طفيفـا أدخله بلباقـة وحكمـة، مبينـا للصسوفية أنسه منصف لهم في نقده وتقييمه، وقد نظرنا إلى هذا على أن فيه جانبا إصلاحيا. ولسائل أن يسأل: لماذا الاهتمام والدعم والترويج للتصوف ضمن مشروع عقلاني،

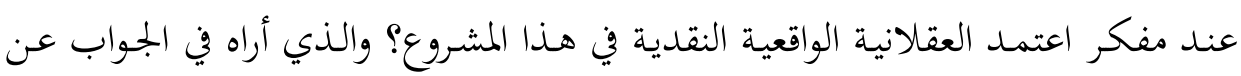

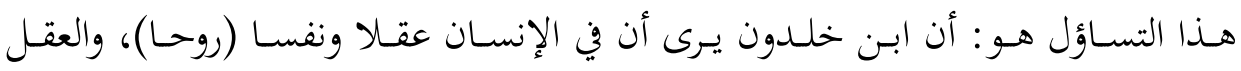

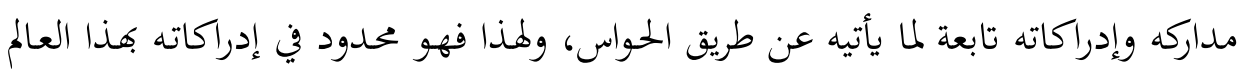

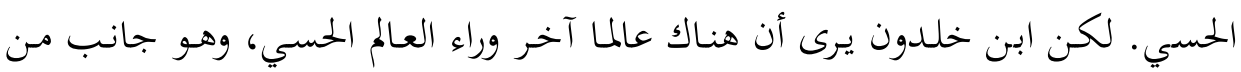

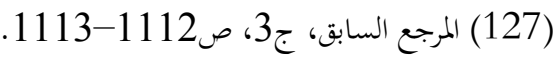

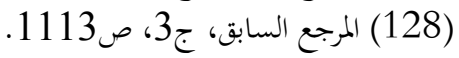

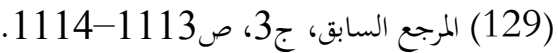

$$
\begin{aligned}
& \text { (130) المرجع السابق، ج3، ص129 المب، ص1114. }
\end{aligned}
$$




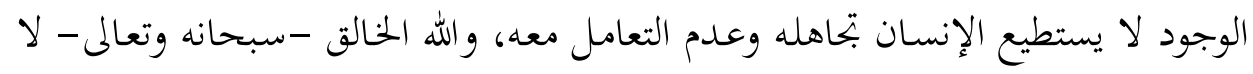

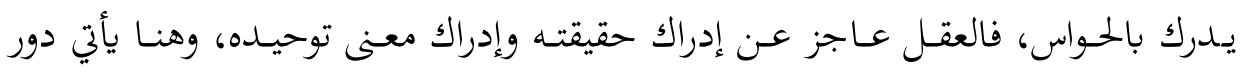

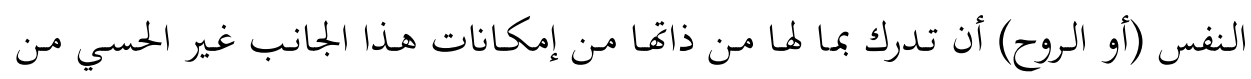

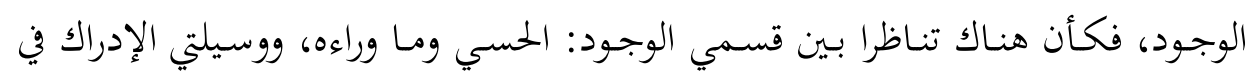

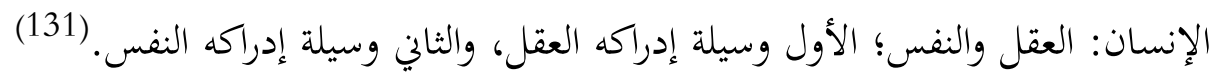

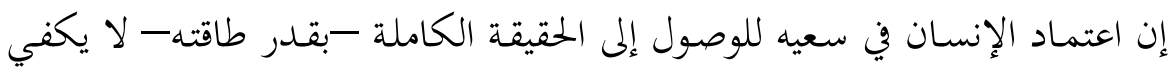

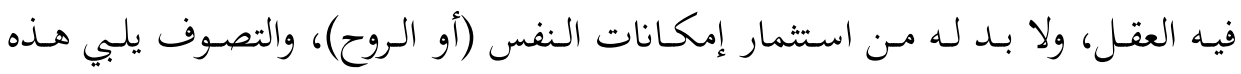

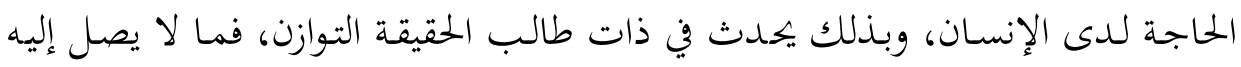

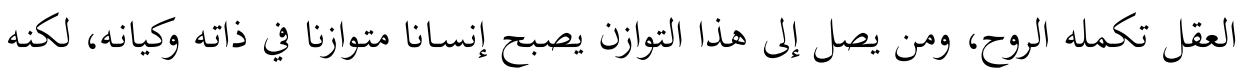

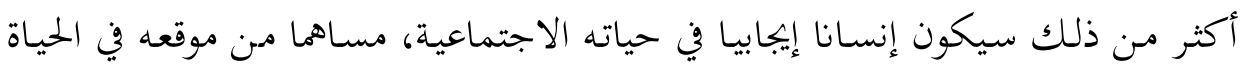

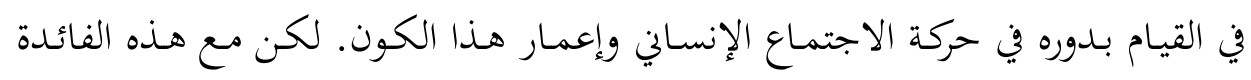

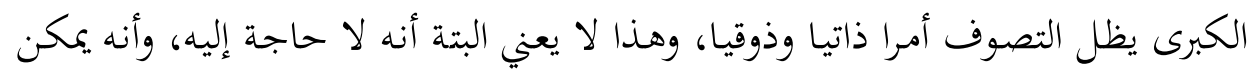

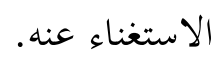

هكذا نرى أن للتصوف مكانا في مشروع ابن خلمدون الفكري التجديدي؛ إذ به إنه

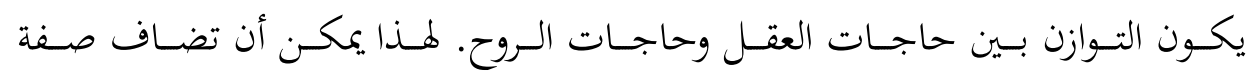

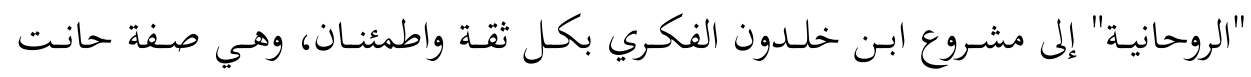

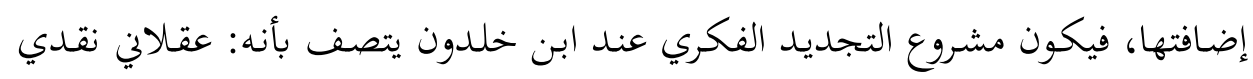
واقعي روحي عملاني.

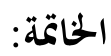

(131) انظر تحليلا ابتمولوجيا دقيقا لهذا الموضوع في: - الجابري: ابستومولوجيا المعقول والأزمة في مقدمة ابن خلدون، مرجع سابق، ص79-95. 
كان هذا البحث اجتهادا في بيان جوانب التجديد الفكري عند ابن خلدون في كل

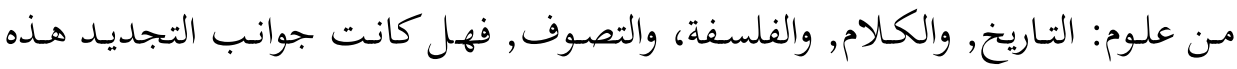

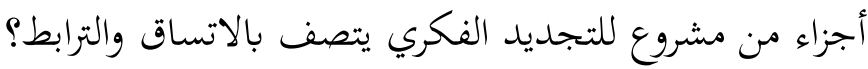

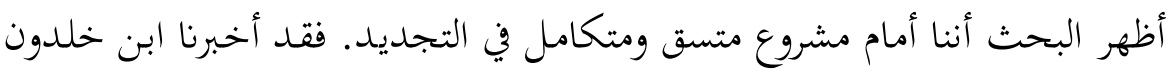

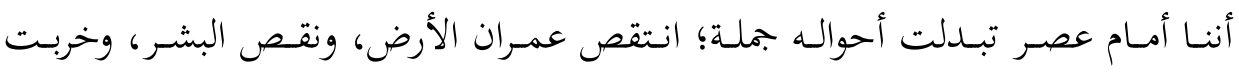

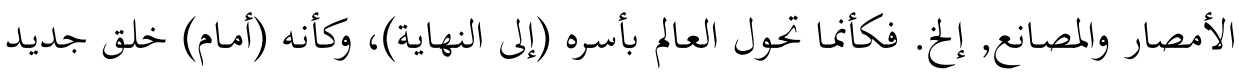

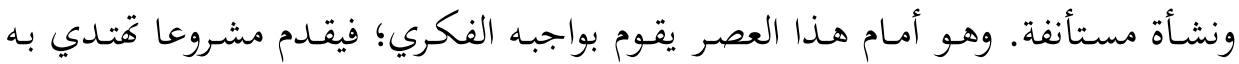

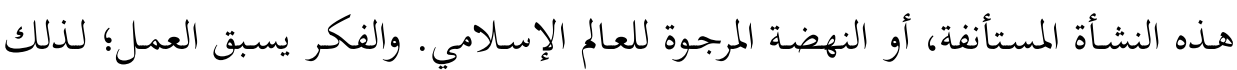

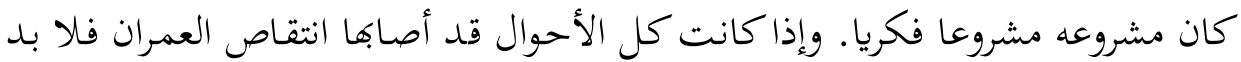
أن يكون المشروع شاملا لكل جوانب الحياة.

وإذا كان العاقل الحكيم يتعلم من أخطاء غيره، ويعتبر بتجارب الآخرين، فإنه لا بد

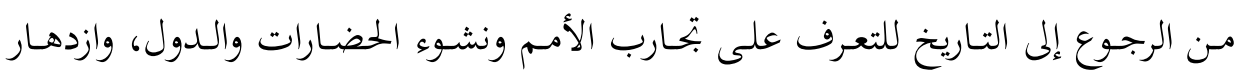

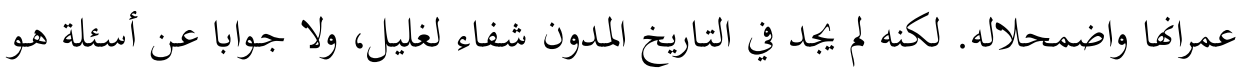

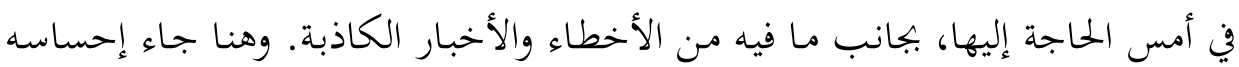
بالمسؤولية المقرون بالثقة بالنفس وبالعزيمة القوية.

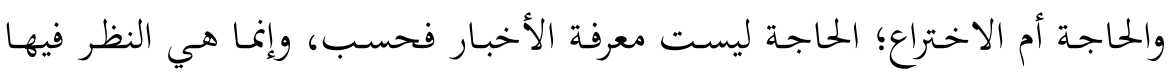

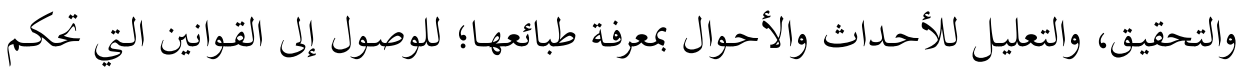

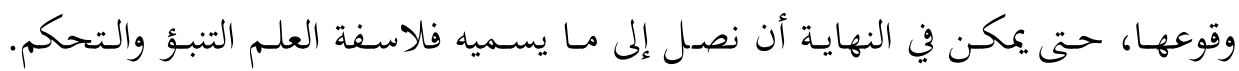

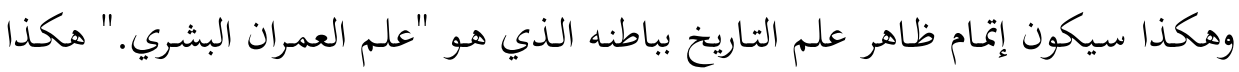

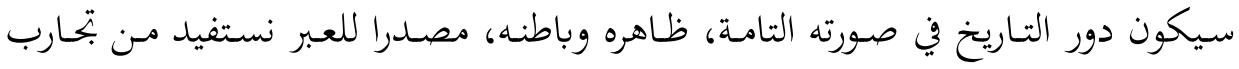
الماضي في قيام الدول والحضارات والعمران في جوانبه المختلفة.

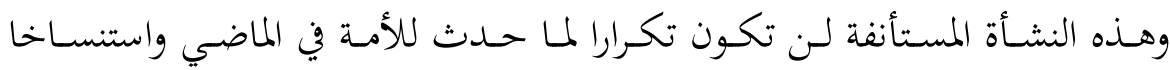

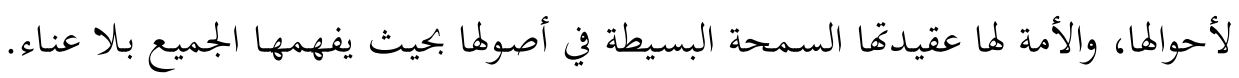


لكن علم الكحلام في صورته التي وصل إليها لا يصلح لتوضيح العقيدة لتكون أساسا

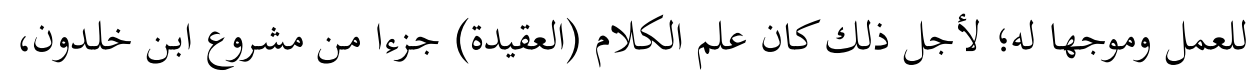
يهدف إصلاحه، ويبين أن جوهر العقائد الإيمانية هو التوحيد، والتوحيد ليس علما نظريا

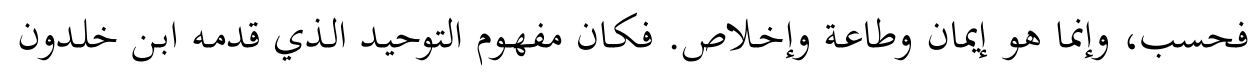

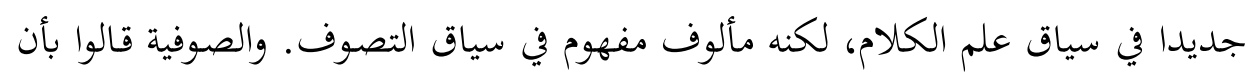

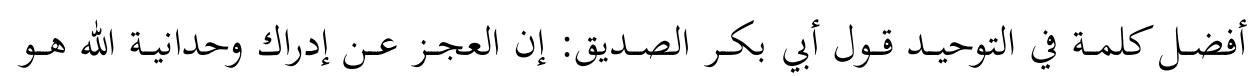

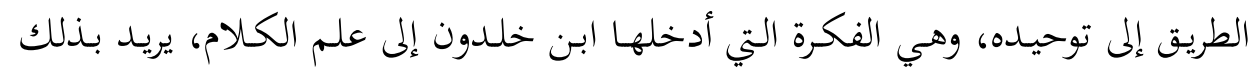

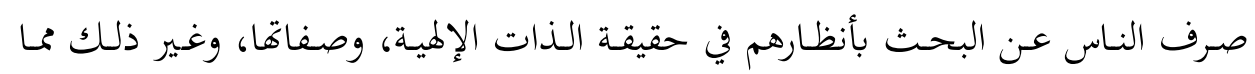

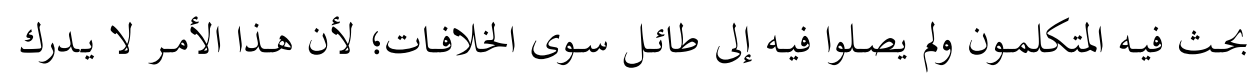
بالعقل, وإنما يدرك بالروح ذوقا وكشفا.

ولأن مقصود ابن خلدون في مشروعه الفكري الوصول إلى أفكار عملية ينبني عليها

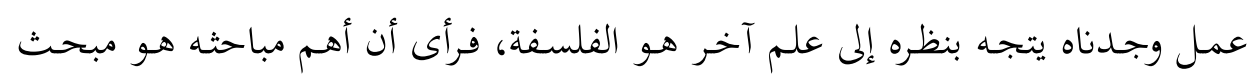

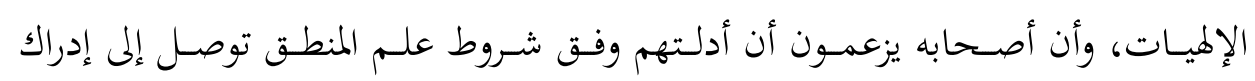

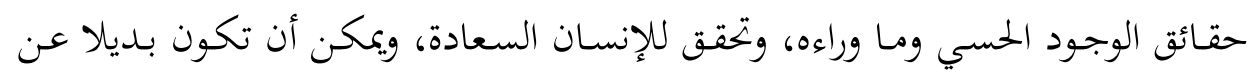

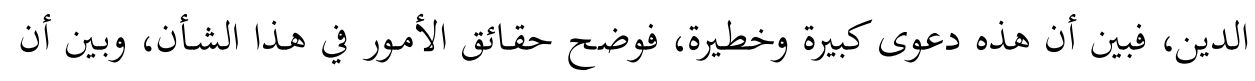
الفلسفة قاصرة، وأقصى مـا تصل إليه في مجال ما وراء الحس أو مـا بعد الطبيعة الظن.

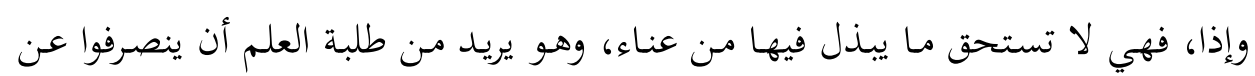

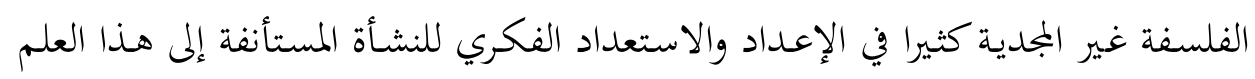
الجميد الذي يوصلنا إلى فهم طبيعة العمران البشري.

ولأن العمران البشري هو بالإنسان ولإِنسان، والنشأة المستأنفة يقوم بها الإنسان، وهذا الإنسان ليس عقلا فحسب، وإنما هو "عقل ونفس (أو روح)، وفاعلية الإنسان في

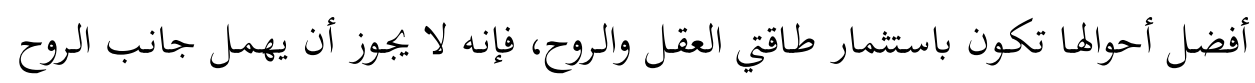

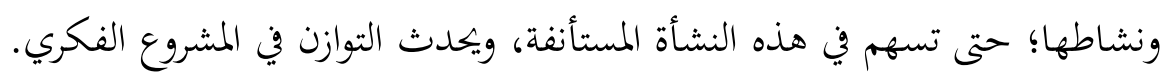


هـذه صـورة مشـروع التجديـد الفكـري عنــ ابـن خلـدون، نحسـب أن الـترابط بـين أجزائها قد توضح، وذلك بالتوجه نحو غاية واحدة، هي الإعداد الفكري لنشأة مستأنفة

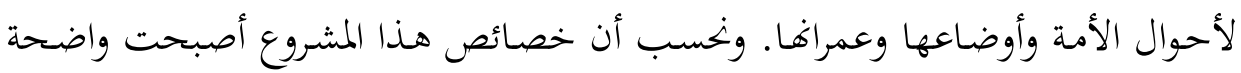

فهو عقلاني يعتمد قوانين العقل والعلوم العقلية. ونقدي؛ لنقده الأوضاع القائمة في

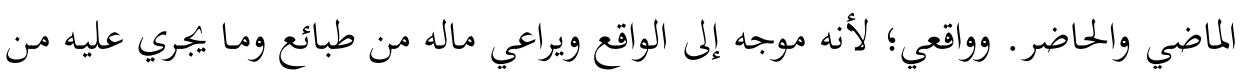

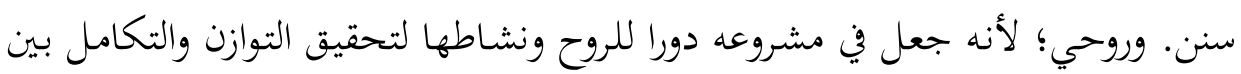

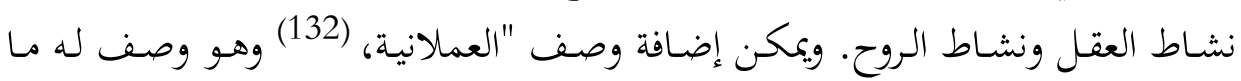

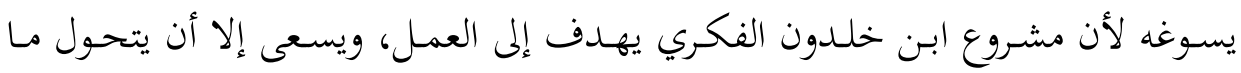

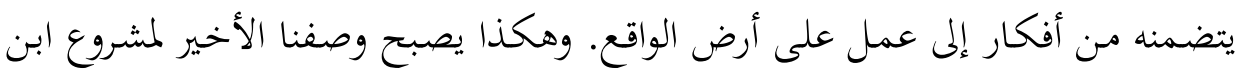
خلدون خماسي الأبعاد: عقلانيا، نقديا, واقعيا, روحيا, عملانيا. تبقى مسألة العبر والدروس التي يمكن لنا، نحن المتأخرين، أن نأخذها من بحربة ابن

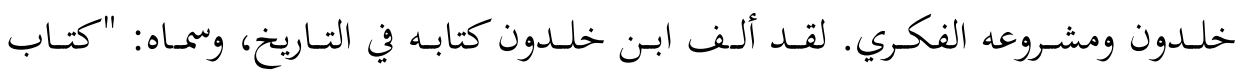
العبر ..." فكأن العبرة والاعتبار هما الهدف العام لدراسة التاريخ وبتحاربه ووقائعه. والعبرة يمكن أن تتحقق حتى لو كان الزمان غير الزمان، وكانت الأحوال غير الأحوال. فالاعتبار

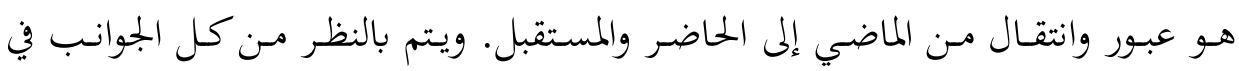

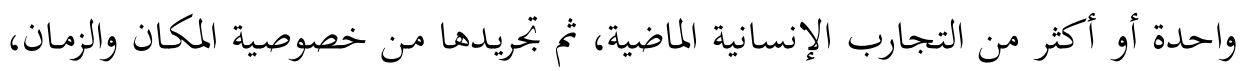
ومن مادة الوقائع والأحداث؛ لتبقى لدينا صورة التجربة عارية عن أي علائق ممثلة لزمان

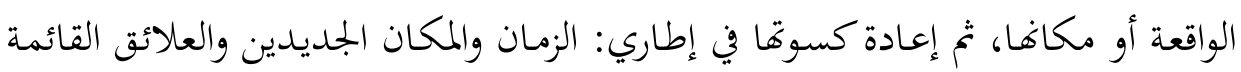
فيهما؛ لإنجاز تجربة إنسانية جديدة يتوقع لها النجاح والبعد عن الأخطاءة إنساء

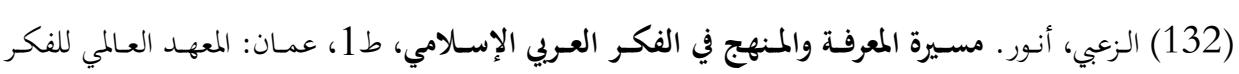

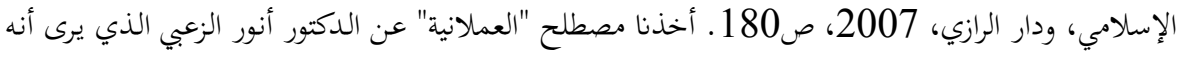
يعبر عن النزعة العملية الذرائعية في فكر ابن خلدون. 
إن الحاجة إلى الاعتبـار هي أشـد مـا تكون عند الأزمات، أو تدهور الأحوال. وقد

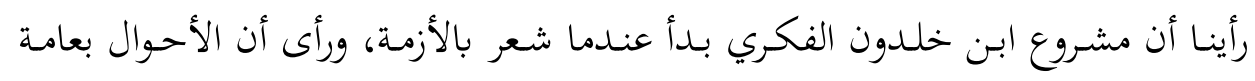
بحاجة إلى نشأة مستأنفة وبداية جديدة، والأمة اليوم تشعر بالحاجة إلى النشأة المستأنفة،

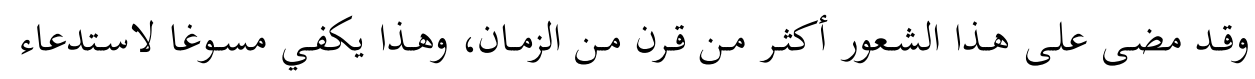

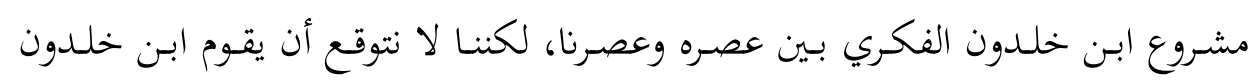
باقتراح الحلول العملية لمشكلاتنا وأزمتنا.

وهـذه أبـرز العـبر التي يقـدمها المشـروع الفكـري التجديـدي لابسن خلـدون في ضـوء الوصف الخماسي الأبعاد لهذا المشروع: 1 1. عـبر العقلانيـة، وتنطـوي على التحديـــ الإجرائسي للسـلوك العقـلاني النظـري

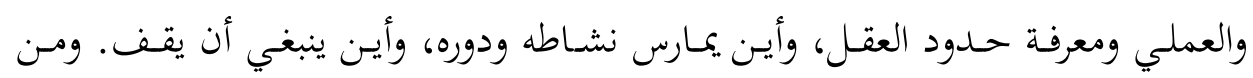

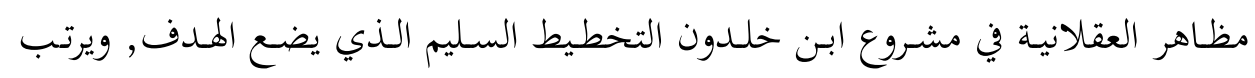
الخطوات الموصلة إليه ترتيبا يحصل به الانتظام والنظام في أفعالنا. ومن مظاهرها -أيضاالبحث عن أسباب الأحداث والوقائع الطبيعية وفقا لطبائع الأشياء والأحوال.

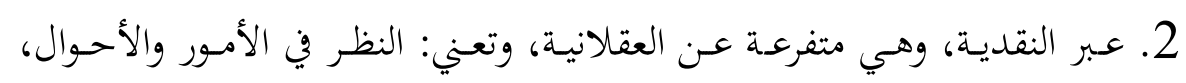

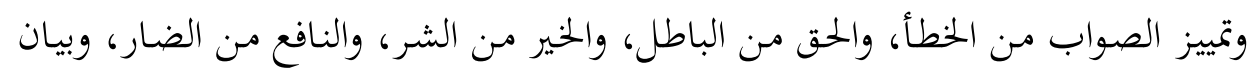

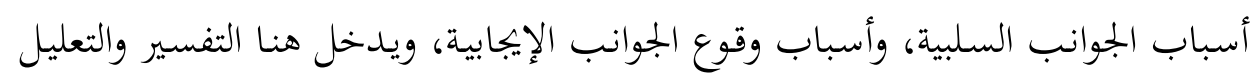
الممهدان للتنبؤ والتحكم.

3. عبر الواقعية، وتعني -فيما تعني- الرجوع إلى الواقع وما جرى فيه بالفعل، فما

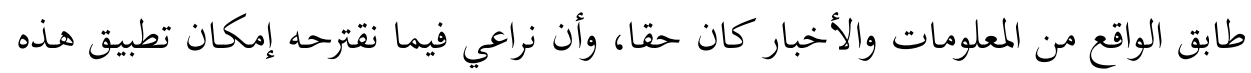

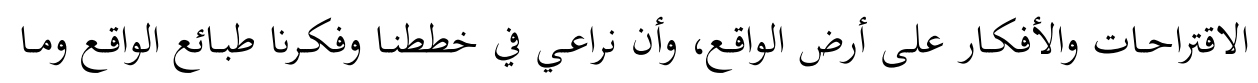
فيه من أحوال وأوضاع وتغيرات. 4. عـبر الروحانيـة، وتعني: أن لا نغفـل حقيقـة أن الروح جـزء ومكـون رئسيس مـن

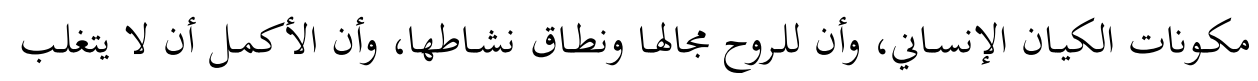


جانب العقل على جانب الروح أو العكس، وأن نجتهد في تحقيق هذا التوازن في سلوكنا

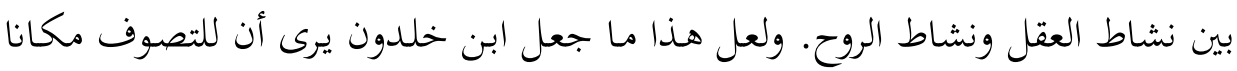
في مشروعه الفكري، وهو أيضا -في جانب منه- يسوغ الاهتمام بالعلوم النقلية بعامة. 5. عبر العملانيـة، وهي صفة من صفات مشروع ابن خلدون؛ إذكان يريـد من العلم والفكر أو يؤديا إلى عمل يتجسد على أرض الواقع، وهذه صفة إسلامية سادت في في صني

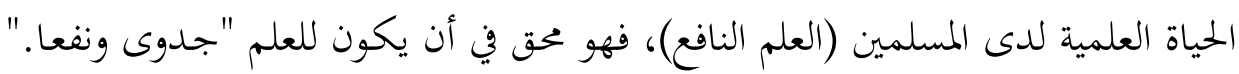
وبهذا المعيار انتقد علم الكالام في بعض المباحث التي لا يترتب عليها عمل. هذه عبر فيها صفة العموم، وثمة عبر أكثر تحديدا، منها: - تعميق دراسة التاريخ بالفلسفة (البحث عن الحقيقة والكلية والتعمق)، وجذب الفلسفة إلى الواقع وتقريبها بالتاريخ. - ضـرورة التمييز بـين العلوم بمعرفة موضـوع كل علم, ومسـائله, وغايتها, ووظيفته،

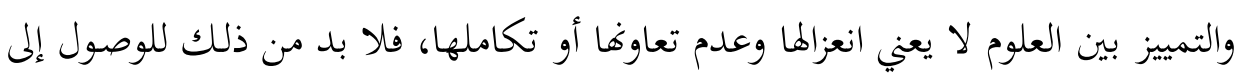
الحقيقة الأصوب والعمل الأتم. والمشروع النهضوي للأمة بحاجة إلى تضافر كل العلوم. - لا ينبغي التفكير في الإصلاح والتجديد باستخدام إطار مرجعي من بيئة وحضارة

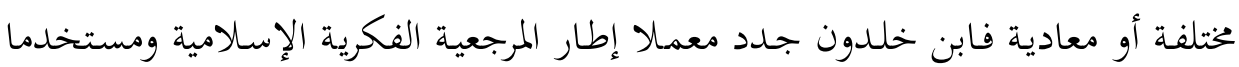
المفاهيم المعتمدة الراسخة فيها، وأضاف إليها.

- الابتعـاد في علم الكـلام عـن بحـث القضـايا التي "لا جـدوى منهـا ولا نفـع" ولا

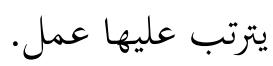

- عـدم معرفـة حقيقـة الفلسـفة ووظيفتهـا في ضـوء تاريخهـا جعـل بعض أتباعهـا

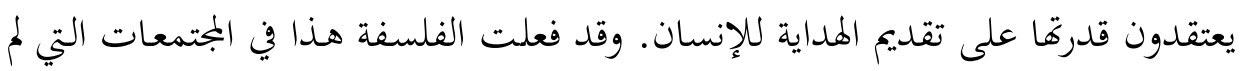

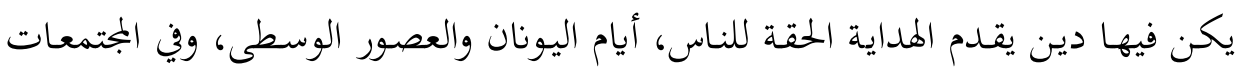


142 إسلامية المعرفة، السنة الثالثة عشرة، العدد 50، خريف 1428هـ/2007 عزمي طه السيد

العلمانية الغربية في العصر الحديث. أما وظيفة الفلسفة في المجتمع الذي يسوده الإسلام فهي البحث العقلي للوصول إلى الحقائق، وخدمة الحقائق الدينية.

- التصوف الحق المنضبط بضوابط الشرع والعقل يحقق التوازن في الحياة والفكر.

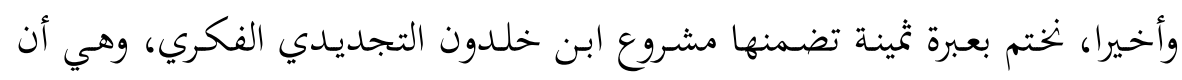

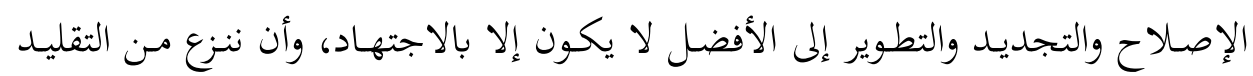

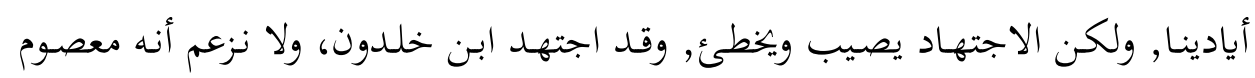
عن الخطأ، لكننا نرى أن صوابه كان هو الغالب. 